\title{
CAPITAL FLOWS, INSTITUTIONS, AND FINANCIAL FRAGILITY
}

\author{
Wipawin Promboon
}

A dissertation submitted to the faculty of the University of North Carolina at Chapel Hill in partial fulfillment of the requirements for the degree of Doctor of Philosophy in the Kenan-Flagler Business School (Finance).

Chapel Hill

2009

Approved by:

Advisor: Gregory W. Brown

Reader: Jennifer Conrad

Reader: Robert Connolly

Reader: Christian Lundblad

Reader: Larry Chavis 
(C)2009

Wipawin Promboon

ALL RIGHTS RESERVED 


\section{ABSTRACT \\ WIPAWIN PROMBOON: Capital Flows, Institutions, and Financial Fragility \\ (Under the direction of Gregory W. Brown)}

This dissertation studies the mechanism through which international capital flows are transmitted from the banking sector to the real sector in a bank-based open economy when moral hazard problems are present. It also examines the role of the quality of institutions and domestic policies in reducing moral hazard problems and in determining the net benefit of international capital flows to a country. A general equilibrium model, incorporating moral hazard problems at the bank, corporate and international levels, is developed to explain this mechanism. In this unifying model, the three layers of moral hazard problems and international capital flows reinforce one another to amplify the boom-bust cycle of an economy, as seen in several crisis countries. The model predicts that an economy will never reach a steady state when banks can accumulate losses and finance those losses through foreign borrowing. This prediction underlines the role of international capital flows and the moral hazard problems at the bank and international levels in destabilizing an economy. The results from the parameter estimation and the hypothesis testing using Thailand data suggest that there have been structural changes in the quality of institutions and domestic policies after the Asian financial crisis and these changes help alleviate the moral hazard problems at all levels in Thailand. Based on the simulation exercises, the improvement in banking supervision and foreign investors' risk estimation helps substantially reduce the bailout costs and the output losses during the recession. In contrast, the reduction in government subsidies or tax incentives hurts, rather than helps, the economy since the cost from the overall output decline outweighs the benefit from the lower bailout costs. 


\section{ACKNOWLEDGEMENTS}

I am grateful to my advisor, Gregory W. Brown, for his valuable guidance, support, and encouragement. I would also like to thank my committee members, Jennifer Conrad, Christian Lundblad, Robert Connolly, and Larry Chavis, for their inspirations and suggestions. I owe very special thanks to Stanley W. Black and Eric Ghysels for their useful advice. Helpful comments and suggestions from Pab Jotikasthira, Anusha Chari, Sergiy Peredriy, Bumjean Sohn, and Jason C. Jones are much appreciated. Finally, I would like to thank my parents, brothers, and friends for their encouragement and support. 


\section{TABLE OF CONTENTS}

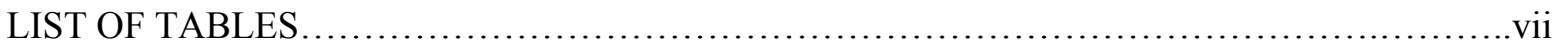

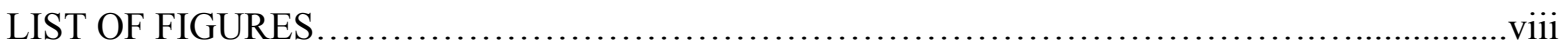

Chapter

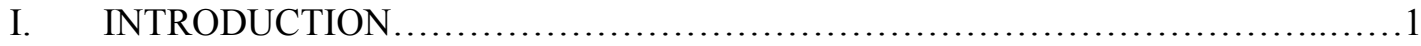

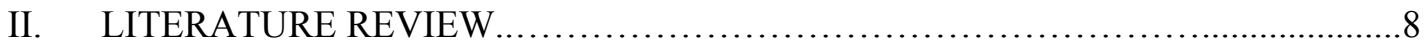

III. EMPIRICAL EVIDENCE SUPPORTING THE KEY MODEL

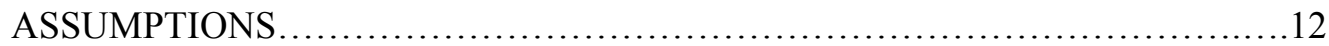

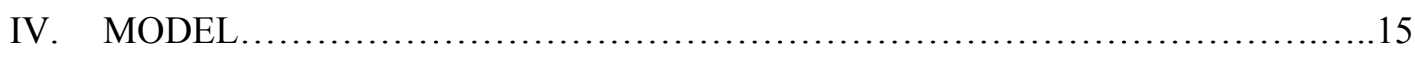

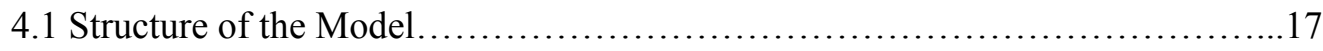

4.2 Sudden Stop Financial Crisis.................................................... 31

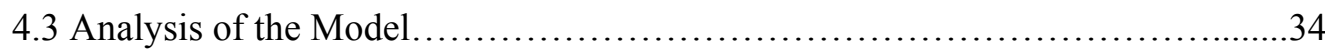

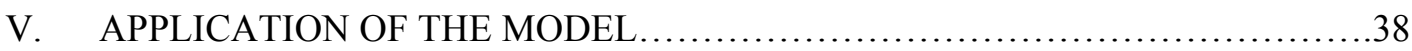

5.1 Parameters of Interest............................................................. 40

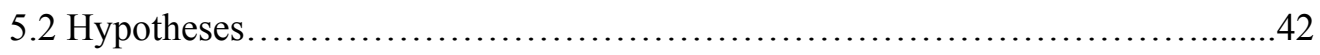

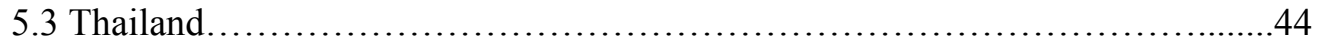

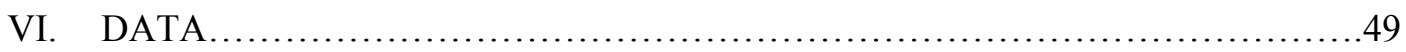

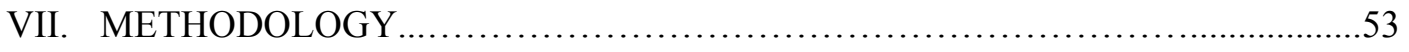

7.1 Model Modifications ...........................................................

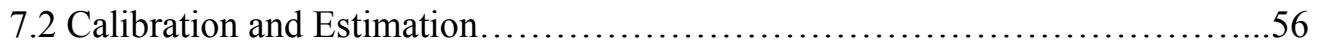

7.3 GMM and Hypothesis Testing Methodology .................................57 


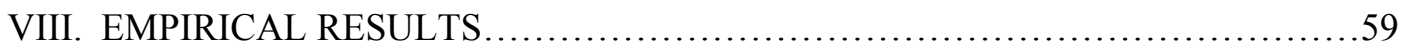

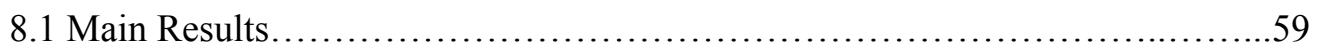

8.2 Sensitivity and Stability Analysis......................................62

IX. SIMULATION.......................................................69

9.1 Costs and Benefits of International Capital Flows.........................69

9.2 Conjectures about the Results..................................... 70

9.3 Scenarios........................................................ 72

9.4 Assumptions.................................................... 73

9.5 Simulation Results............................................. 74

9.6 Sensitivity Analysis............................................... 78

X. MISSING COMPONENTS OF THE MODEL AND AREAS FOR

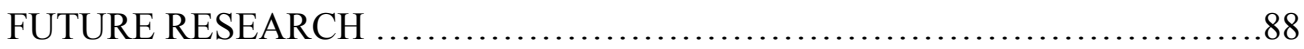

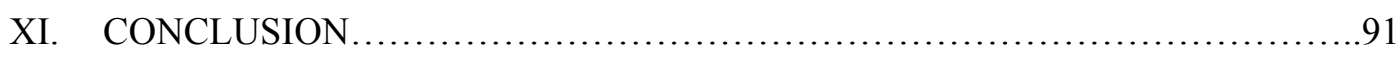

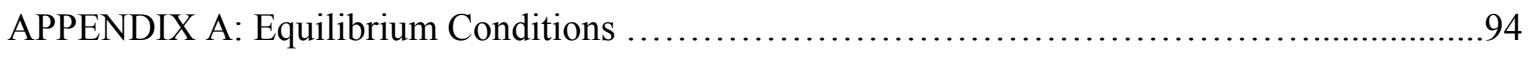

APPENDIX B: Parameters and Variables...........................................98

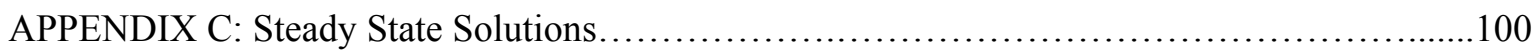

APPENDIX D: Linear Approximations and Solutions for Linearized Difference Equations........103

APPENDIX E: Equilibrium Conditions in the Form of First Difference Equations...............107

APPENDIX F: Descriptions and Data Sources of Variables Used as Instruments................109

APPENDIX G: Steps to Calculate Partial-Sample GMM Estimators and Wald Statistics........110

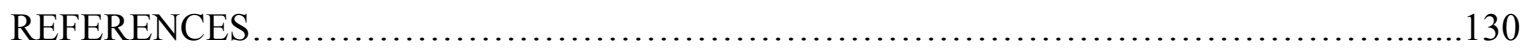




\section{LIST OF TABLES}

Table

1. Descriptions and Data Sources of Variables......................................115

2. Summary Statistics for the Whole Sample Period................................119

3. Summary Statistics for Each Sub-Period.......................................120

4. Preliminary Correlation Analysis......................................... 122

5. Correlations between Selected Macroeconomic Variables and Relevant Interest Rates.......................................................... 123

6. Exogenously-Determined Parameters..........................................124

7. Parameter Estimates from Partial-Sample GMM Estimation..........................125

8. Wald Statistics for Structural Break Tests.................................... 126

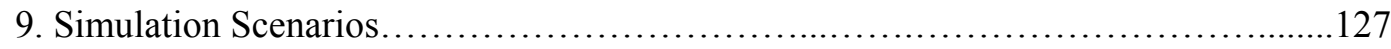

10. Direct and Indirect Costs in Comparison with the Actual Data....................128

11. Direct, Indirect, and Total Costs Relative to the Base Scenario......................129 


\section{LIST OF FIGURES}

Figure 1. Time-Series Patterns of Variables............................................. 113 


\section{CHAPTER I}

\section{INTRODUCTION}

Recent globalization of economic activity and financial markets triggered financial liberalization in many countries, exposing them to increasing volume of, and higher uncertainty from, international capital flows. This fundamentally altered historic relationships between international transactions and activities of local financial intermediaries. While international capital flows are an important source of capital for a country's real investment, financial risks induced by large short-term international capital flows, or so-called 'hot money', can potentially have an adverse effect on financial system stability. Some anecdotal evidence suggests that financial crises spill over to the real economy and in some cases result in severe macroeconomic dislocation. However, other research instead suggests that financial crises are the result of fundamental macroeconomic conditions. A dramatic example of this debate surrounds the "financial crisis" in East Asia during the late 1990s. A number of papers (e.g., Furman, Stiglitz, Bosworth \& Radelet, 1998; Radelet, Sachs, Cooper \& Bosworth, 1998) highlight the major role of international capital flows in determining the financial instability and resulting contagion. In contrast, some research suggests that the Asian crisis resulted principally from weak fundamentals due to regulatory inadequacy in the banking sector (Kaminsky \& Reinhart, 1999) and moral hazard problems induced by explicit or implicit guarantees from the local government or international organizations (Corsetti, Pesenti \& Roubini, 1999a).

These two views, although different, are not mutually exclusive. As some prior research suggests (e.g., Henry \& Lorentzen, 2003), it is not just the quantity of capital that matters, but also how the capital is utilized. In countries where moral hazard problems are severe, more available capital as a result of financial liberalization may be utilized for bad investments or risky projects. In 
addition, regulatory and institutional capacity to deal with such moral hazard problems may not be able to keep pace with rapid changes in financial markets. The recent subprime mortgage crisis in the U.S. (with major adverse consequences for banks and financial markets around the world) and the Asian financial crisis during the late 1990s highlight the role of international capital flows via the banking sector and moral hazard problems in determining macroeconomic stability of an open economy.

From a policy perspective, more available foreign capital poses a significant risk for a country which liberalizes financial markets too quickly or too broadly without adequate preparation in terms of regulations and institutions (Stiglitz, 1999, 2002; Rodrik, 1998). To the contrary, excessively slow financial market liberalization could lead to low and inefficient investment, suboptimal risk-sharing (exacerbated home-bias), and relatively slow economic growth as implied by Bekaert, Harvey and Lundblad (2005). All these debates motivate two important research questions: (1) What is the net effect of international capital flows on a country? (2) Are institutions as important as suggested by other research or are they a proxy for other factors?

Given the clear importance of these issues, a number of researchers have studied the determinants as well as the costs and benefits of international capital flows to a country. Many of them focused only on the costs (e.g., Hutchison \& Noy, 2006; Boyer, Kumagai, \& Yuan, 2006) or the benefits of financial liberalization (e.g., Bekaert et al., 2005; Henry, 2000a, 2000b). Also, the empirical results regarding the benefits of capital flows are mixed. Hence, the issue of whether international capital flows are truly destabilizing remains unresolved. In addition, most of those studies are cross-country. Thus, they cannot account for all types of heterogeneities across countries nor can they analyze the factors driving the costs and benefits of international capital flows, such as the quality of institutions, for each country in detail. The issue of whether the quality of institutions matters therefore has not been thoroughly explored at the detailed country level. Looking at an 
economy that has made institutional changes and estimating the impact is a way to investigate both if institutions really matter, and if so, how much.

This dissertation aims to (1) study the transmission mechanism of international capital flows via the banking sector to the real sector of an open economy when moral hazard problems are present in a unified structural framework and (2) examine the role of the quality of institutions and domestic policies in reducing moral hazard problems and determining the net benefit of international capital flows to a country in the long run. The focus of this paper is primarily on small open economies for the following reasons. First, those countries experienced an influx of international capital flows after their financial liberalizations and many went through financial crises with sudden reversals of capital flows. Hence, they are good subjects for examining both the costs and benefits of international capital flows. Second, several of them, especially those that experienced crises, have undergone major reforms and significant changes in the quality of institutions and domestic policies after the crises. Such reforms can then be used to examine the effects of changes in the quality of institutions and domestic policies on those countries.

To address the first objective, a theoretical model under the general equilibrium framework is developed to explain the interactions between international capital flows and each sector of a small open economy during both non-crisis and crisis periods when moral hazard problems are present. This model incorporates several important facets of the real and financial economy, allowing shocks to the banking sector to be transmitted to the real sector, and vice versa, via the interest rate mechanism. It also addresses several aspects of moral hazard problems, rather than focusing on only one of them as many other moral hazard models have done (e.g., Corsetti, Pesenti, \& Roubini, 1999b; Dekle \& Kletzer, 2005). The unifying property of this model allows interactions between different aspects of moral hazard problems as they could be reinforcing or offsetting one another. This property also makes the model more consistent with what has been observed, as there exist multiple types of moral hazard problems, although in different degrees, in most countries. Hence, compared 
with other moral hazard models, this model is more versatile and so is applicable to a broader set of countries.

The main assumptions of the model are based on key observations of countries experiencing crises over the past two decades. First, an economy is largely reliant on the banking sector, which has access to large sources of international funds. Second, due to poor quality institutions and domestic policies, there are three layers of moral hazard problems in the country before a crisis (i.e., moral hazard problems at the corporate, bank, and international levels). ${ }^{1}$ Third, a sudden stop of international capital flows is triggered when the expected level of contingent government liabilities (the amount of banks' cumulative losses) exceeds the level of the country's international reserves. In this model, the three layers of moral hazard problems, together with international capital flows, reinforce one another to amplify the boom-bust cycle of the economy.

First, at the corporate level, expected government subsidies or tax incentives increase firms' expected profits, inducing firms to invest more and borrow more from banks than they should without the government subsidies or tax incentives. In the model, a firm's optimal level of capital stock is increasing with the level of government subsidies or tax incentives.

Second, at the bank level, when a future government bailout is expected and banking supervision is inadequate, banks are willing to lend excessively to the corporate sector as long as they can obtain enough funding from depositors (the household sector) and foreign creditors. In addition, banks have an incentive to pay out their profits from performing loans as dividends to their shareholders, rather than maintaining such profits as provisions against their losses from nonperforming loans (NPLs). Hence, NPL losses are accumulated on the banks' accounts, and banks have to finance those losses through additional foreign borrowing. In this model, the level of NPL losses that banks can accumulate in each period is determined by their loan loss provisioning ratio.

\footnotetext{
${ }^{1}$ As mentioned in Corsetti et al. (1999a), the role of moral hazard at the onset of the Asian crisis has been stressed by a number of authors, e.g., Krugman (1998a), Greenspan (1998), and Fischer (1998b).
} 
Third, at the international level, with a presumption that government guarantees exist and the government is committed to a stable exchange rate, foreign creditors are willing to lend excessively to the domestic banking sector as long as the expected level of the government's contingent liabilities is below the level of the country's international reserves. They also underestimate the risks from their lending to the domestic banking sector and do not charge interest rates high enough to compensate for their risks, because they believe that the government will bail out those banks if things go wrong. In addition, they do not expect exchange rates to be responsive to changes in interest rate differentials since they believe that the government will attempt to maintain a stable exchange rate. In this model, foreign investors' perceptions of risks and their expectations of exchange rate movements are reflected in the determination of a domestic interest rate and an exchange rate. Particularly, the banks' cost of foreign borrowing is modeled to be increasing with the aggregate level of banks' net foreign borrowing. Although extending more credit to the banking sector in another country exposes foreign investors to higher risks, they may not fully take into account those risks when determining the rate of return if they believe that government guarantees exist. The sensitivity of the banks' foreign borrowing rate to the aggregate level of banks' net foreign borrowing thus reflects the level of risks that foreign investors perceive and factor into their required rate of return. The higher this sensitivity, the more expensive it is for banks to increase their foreign borrowing. The exchange rate in this model is determined by an interest rate differential and an expected exchange rate deviation from the uncovered interest rate parity (UIP) relation according to a modified UIP. When the expected exchange rate deviation from the UIP is equal to zero, the exchange rate is solely determined by the interest rate differential and is not influenced by the government.

Although moral hazard problems at all levels play a role in magnifying the boom-bust cycle of an economy, the analysis of the model suggests that the moral hazard problems at the bank and international levels are primarily the factors causing an economy to move away from its equilibrium and triggering a sudden stop and a crisis. When banks can accumulate NPL losses (the moral hazard 
problem at the bank level) and can obtain additional foreign borrowing to finance those losses (the moral hazard problem at the international level), the economy will never be at a steady state, as NPL losses and foreign debt continue to increase. Once the level of banks' cumulative NPL losses exceeds the level of the country's international reserves, a sudden stop will surely occur.

To address the second objective, the model parameters measuring the severity of moral hazard problems are used as proxies for the quality of institutions and domestic policies. A crisis country typically has gone through major institutional reforms after a crisis. Hence, its quality of institutions and domestic policies may be significantly changed, and its moral hazard problems may have been reduced. If this hypothesis is true, the parameters measuring moral hazard problems should indicate a lower degree of moral hazard problems after a crisis. In addition, since the moral hazard problems, together with international capital flows, amplify the boom-bust cycle of an economy, the lower degree of moral hazard problems may result in lower cost or higher benefit of international capital flows to a country.

To examine the above hypotheses, the parameters determining moral hazard problems at all levels are estimated for pre-crisis, crisis, and post-crisis periods using the equilibrium conditions from the model and the generalized method of moments (GMM) approach to fit the data of a small open economy which has experienced a crisis. The chosen country is Thailand since it exhibits characteristics consistent with the key assumptions of the model. It is also not an extreme example, considering its rankings among all other emerging countries in terms of its degree of openness, economic performance, and quality of institutions. The hypothesis tests for the differences in parameter values before and after the crisis are conducted to examine if there have been significant changes in the quality of institutions and domestic policies leading to a lower degree of moral hazard problems after the crisis. Simulation exercises are also undertaken to assess the impact of changes in the quality of institutions and domestic policies on the net benefit of international capital flows. Both direct costs (bailout costs) and indirect costs (output losses) of a crisis with a sudden stop of capital 
flows are estimated using the simulated data under different moral hazard scenarios. The results from the hypothesis testing and the simulation exercises suggest that the moral hazard problems at all levels are less severe after the crisis and the changes in the quality of institutions and domestic policies with regard to banking supervision and foreign investors' perceptions of risks help significantly reduce the bailout costs and the output losses. In contrast, the reduction in the government subsidies or tax incentives to the corporate sector hurts, rather than benefits, the country, as the cost from the lower output outweighs the benefit from the lower bailout costs.

The rest of this dissertation is organized as follows. Chapter II discusses the related literature. Chapter III presents the empirical evidence supporting the key assumptions of the model. Chapter IV develops the theoretical model. Chapter V discusses the application of the model. Chapter VI describes the data and summary statistics. The methodology and estimation results are explained in Chapter VII and Chapter VIII, respectively. Chapter IX presents the simulation results. Chapter X discusses missing components of the model and areas for future research. Chapter XI concludes. 


\section{CHAPTER II}

\section{LITERATURE REVIEW}

The relationships between international capital flows and macroeconomic conditions have been widely studied in the international economics literature. Early literature examined the relationships between capital flows and the saving-investment gap. Fleming-Mundell and ObstfeldRogoff models provide basic theoretical frameworks for analyzing such relationships. Kraay and Ventura $(2000,2002)$ and Ventura (2003) incorporate investment risk into consumers' portfolio composition decisions, which thus determine the domestic capital stock and the net foreign asset position of a country. Motivated by concerns over financial instability caused by international capital flows, a number of researchers examine the mechanisms through which international capital flows create sudden stops and crises (e.g., Calvo, 1998; Rodrik \& Velasco, 1999). Chari and Kehoe (2003) develop a model of herd behavior where informational frictions together with weak fundamentals lead to volatile capital flows (resembling hot money) and in turn cause a financial crisis. Inspired by the market microstructure literature on the relationships between foreign exchange (FX) order flows and FX rates, ${ }^{2}$ more recent works examine the two-way causal relationships between international capital flows and macroeconomic as well as financial market indicators. Hau and Rey (2006) develop a model in which exchange rates, stock prices, and capital flows are jointly determined under incomplete foreign exchange risk trading. Empirical work in this line of research includes Hau and Rey (2004), Siourounis (2003), Froot, O’Connell, and Seasholes (2001), Froot and Ramadorai (2001, 2005) and Powell, Ratha, and Mohapatra (2002). Similar to this literature, this dissertation

\footnotetext{
${ }^{2}$ Vitale (2007) surveys the market microstructure approach to exchange rate determination.
} 
emphasizes the role of the banking sector and moral hazard problems in determining the net benefit of international capital flows to a country.

This dissertation is also related to the literature on currency and financial crises. ${ }^{3}$ The first generation of crisis models was pioneered by Krugman (1979). In this type of model, unsustainable fiscal policy causes the collapse of a fixed exchange rate regime and a crisis. The second generation of crisis models was initiated by Obstfeld (1986). In these models, doubts about the government ability to maintain its fixed exchange rate bring about multiple equilibria, and speculative attacks occur as a result of self-fulfilling expectations, not because of irresponsible policies. The third generation of crisis models examines the role of the banking sector in initiating or amplifying the severity of a crisis (e.g., Disyatat, 2004; Zhou, 2008). The three main versions of the third generation models as suggested by Krugman (2001) are bank run, balance-sheet effect and moral hazard models. In the bank run models (e.g., Chang \& Velasco, 2000, 2001), the focus is on a bank's maturity mismatch, and a bank run occurs based on self-fulfilling expectations that the bank may not be able to pay depositors who come to withdraw their money later. In the balance-sheet effect models (e.g., Burnside, Eichenbaum \& Rebelo, 2001a), banks and firms have an incentive to expose themselves to greater FX risk in the presence of government guarantees.

The model presented in this paper is mostly related to a moral hazard story. The basic feature of moral hazard models (as seen in many papers, e.g., Dooley, 2000; McKinnon \& Pill, 1996) is the role of expected government guarantees in causing international investors to lend a large amount of money to another country, leading to excessive risk-taking behavior of agents in that country. Apart from the moral hazard problem at the international level, there are many other levels of moral hazard problems. With regard to the moral hazard problem at the corporate level, Corsetti, Pesenti, and Roubini (1999b) develop a model in which there are expectations that the government will provide financial support to firms if they are in a bad state. Such expectations increase firms' expected profits

\footnotetext{
${ }^{3}$ Burnside, Eichenbaum, and Rebelo (2008), Krugman (2001), and Tinnakorn (2006) provide a review of crisis models.
} 
and cause firms to overinvest. Firms can easily get funds from overly optimistic elite consumers, who have access to international funds and expect a government bailout when firms are in a bad state. Since firms do not receive transfers from the government right away, elite consumers have to finance their losses or cash shortfalls through foreign borrowing. Once their cumulative losses exceed the level of the country's international reserves, a sudden stop of capital flows occurs. With regard to the moral hazard problem at the bank level, Dekle and Kletzer (2005) develop a model in which banking supervision is inadequate and there is a widely held perception that government guarantees exist. Hence, banks have an incentive to pay dividends from their performing loan profits, rather than maintain them as provisions against their non-performing loan (NPL) losses. Banks therefore accumulate NPL losses, which later become contingent government liabilities. Once the level of banks' cumulative NPL losses exceeds a certain threshold, the government intervenes, and banks can no longer accumulate losses. However, in their model, banks receive funds only from domestic depositors; hence, there is no role for international capital flows. This dissertation addresses several aspects of moral hazard problems, rather than focusing on only one of them. Particularly, the model developed in this dissertation incorporates (1) expected government subsidies or tax incentives to the corporate sector which lead to overinvestment, similar to what we have seen in the paper by Corsetti et al. (1999b), ${ }^{4}$ (2) lax banking supervision which leads to an accumulation of banks' NPL losses, as seen in the paper by Dekle and Kletzer (2005), and (3) expected government guarantees and the government's commitment to a stable exchange rate which cause foreign investors not only to lend a large amount of money to domestic banks, but also to underestimate their risks associated with lending to banks in another country. Hence, this model is more applicable to countries with multiple moral hazard problems. In addition, unlike many other theoretical papers, model parameters are estimated, rather than calibrated, in the empirical analysis.

\footnotetext{
${ }^{4}$ In this model, expected government subsidies or tax incentives to the corporate sector are modeled differently. Unlike the model by Corsetti et al. (1999b), subsidies from the government to the corporate sector in this model are contemporaneously provided to all firms in each period, rather than provided only to low-type firms and accumulated as the government's expected contingent liabilities.
} 
Regarding the costs and benefits of international capital flows, a large number of researchers explore the fundamental issue of whether foreign capital flows are destabilizing or benefiting a country or both. Quinn (1997) and Bekaert et al. (2005) find that countries with greater openness to capital mobility experience higher growth than countries with restrictions on capital mobility while Rodrik (1998) finds no such association. To the contrary, Hutchison and Noy (2006) find that sudden-stop crises--currency/balance of payment crises with reversals in capital flows--have a large negative, but short-lived, impact on output growth (over that found in other crises without reversals in capital flows).

Interestingly, the benefits of financial liberalization might not be as strong as expected due to agency problems arising when rulers of sovereign states and corporate insiders pursue their own interests at the expense of outside investors (Stulz, 2005) and inadequacy of laws and supporting institutions (Henry \& Lorentzen, 2003). However, this issue has not been thoroughly explored at the detailed country level. This dissertation adds to this line of research by further examining the role of the quality of institutions and domestic policies in reducing moral hazard problems and in determining the net benefit of international capital flows to a country. Particularly, the parameter values associated with the severity of moral hazard problems are estimated and used to assess the effect of changes in the quality of institutions and domestic policies on the costs and benefits of international capital flows in the simulation exercises. 


\section{CHAPTER III}

\section{EMPIRICAL EVIDENCE SUPPORTING THE KEY MODEL ASSUMPTIONS}

The main assumptions of the model developed in the next chapter are based on key observations of countries which have experienced financial crises. Over the past couple decades, a number of crises have occurred around the world, e.g., Mexican Peso crisis during 1994-1995, Asian financial crisis during 1997-1998, Russian financial crisis in 1998, Argentine economic crisis during 1999-2002. The most recent global financial crisis resulted from the subprime mortgage crisis in the U.S. and has had a large adverse impact on financial markets and economies around the world. For example, the Icelandic financial crisis has resulted in the collapse of all three major banks in Iceland. Those crises share several similarities.

First, international capital flows played a key role in fueling a boom, and in many of those countries the banking sector played an important role in channeling funds to the real sector. At the end of 1997 , bank loans accounted for $77 \%$ of the total external finance for Thailand, $68 \%$ for Indonesia, $52 \%$ for the Philippines, and $65 \%$ for South Korea while in the U.S. bank loans represented only $23 \%$ of the total external finance. ${ }^{5}$ Also a large fraction of foreign borrowing was intermediated by the domestic banking system. Based on Bank for International Settlements (BIS) data on foreign liabilities of domestic banks and non-banks towards BIS reporting banks, in mid 1997, the ratio of foreign borrowing intermediated by the domestic banking sector was $77 \%$ for Malaysia and Korea, $69 \%$ for the Philippines, $86 \%$ for Thailand, and $78 \%$ for China (Corsetti et al., 1999a).

\footnotetext{
${ }^{5}$ These ratios are calculated using the figures from Expert Group on the Challenges of the Asian Economy and Financial Markets (2001), which are based on International Financial Statistics data of the International Monetary Fund (IMF-IFS).
} 
Second, there were typically structural and policy distortions before each crisis, which caused the private sector (or the public sector in the case of Mexico, Russia and Argentina) of a crisis country to excessively accumulate debt and then trigger a financial crisis. Particularly there was a widely held perception that explicit and/or implicit government guarantees or subsidies for corporate and financial investment existed, causing firms to overinvest, banks to lend excessively to risky borrowers, and foreign capital to flow into a country. Furthermore, several of the crisis countries adopted rigid exchange rate regimes, for example, pegged exchange rates in Thailand, Argentina, and Mexico and managed float regimes in Korea, Indonesia, and Russia. Worsening the situation, banking supervision was typically quite lax before a crisis. Hence, several banks, such as commercial banks in many Asian countries and Iceland as well as investment banks in the U.S., had an incentive to take excessive risks to enhance returns.

Third, a sudden stop of capital flows and a run occurred when the expected level of a country's debt (either public or private debt) was so high that investors did not believe that the government would be able to fulfill its financial obligations. In fact, there were several signs of a country's vulnerability to a crisis and a sudden reversal of capital flows in those crisis countries. Many of them had current account imbalances before a crisis and thus were susceptible to a sudden reversal of capital flows, especially when such imbalances were financed by short-term flows or by instruments indexed to other currencies. For example, Thailand experienced a current account deficit for over a decade, and by 1996 only 16\% of its current account deficit was financed by foreign direct investment (FDI) (Corsetti et al., 1999a) while Mexico financed its current account deficit of 7\% of GDP by debt instrument denominated in pesos but indexed to dollars. In addition, there was a lending boom prior to a crisis. In countries experiencing the Asian financial crisis, the ratio of private sector lending to GDP exhibited an increasing trend. The growth rate during 1990-1996 of private sector lending to GDP ratio was highest in the Philippines (151\%), Thailand (58\%), and Malaysia (31\%) (Corsetti et al., 1999a). In the U.S., the home ownership rate increased from 64\% in 
1994 to $69.2 \%$ in 2004 , and subprime lending was a major contributor to this increase. In several crisis countries, asset quality was in doubt. The non-performing loans to total loans ratio in 1996 was estimated to be $13 \%$ for Thailand and Indonesia, $8 \%$ for Korea, $10 \%$ for Malaysia, and $14 \%$ for the Philippines (Corsetti et al., 1999a). Moreover, there was a serious mismatch between foreign liabilities and foreign assets in many crisis countries. The ratio of foreign liabilities to foreign assets relative to BIS reporting banks exceeded $100 \%$ in countries experiencing the Asian financial crisis during 1993-1997 (Corsetti et al., 1999a).

Based on the above key observations, the model in Chapter IV is developed using the following assumptions: (1) the banking sector plays a key role in channeling international capital flows to the corporate sector, (2) moral hazard problems at the corporate, bank, and international levels are present in an economy, and (3) a sudden stop of capital flows occurs when the expected level of the country's debt is greater than the level of the country's liquid assets. 


\section{CHAPTER IV}

\section{MODEL}

This chapter presents a general equilibrium model of a bank-based, small open economy with moral hazard problems. The focus of this model is primarily on small open economies since those countries experienced an influx of international capital flows after their financial liberalizations and many of them underwent financial crises with sudden reversals of capital flows. Hence, they are good subjects for examining both the costs and benefits of international capital flows. Moreover, several of them have gone through major institutional reforms after the crises. Such reforms can then be used to examine the impacts of changes in the quality of institutions and domestic policies on those countries. Although the model in this chapter is developed for a small open economy, it can be extended for a large open economy by endogenizing the world interest rate.

This model is developed with the aim of explaining the relationship between international capital flows via the banking sector and the real economy, the occurrence of a financial crisis, and how moral hazard problems amplify the impact of international capital flows on a country. The model incorporates several important aspects of the real and financial economy, allowing shocks to one sector to be transmitted to the others through interest rates. It also combines and extends the crisis models by Corsetti et al. (1999b) and Dekle and Kletzer (2005) to simultaneously address the three levels of moral hazard problems (i.e., the corporate, bank and international levels), which are normally observed in a crisis country. The unifying property of this model allows interactions between different levels of moral hazard problems as they could be reinforcing or offsetting one another. 
Following the idea of Corsetti et al. (1999b), the moral hazard problem at the corporate level results from expected government subsidies or tax incentives, which increase firms' expected profits and induce firms to overinvest. There are different ways to model this level of moral hazard problem. First, it can be assumed that there is an anticipation of a future corporate bailout only to firms that are in a bad state (low-type firms) so that they can at least break even and survive, as seen in the model by Corsetti et al. (1999b). Hence, the expected number of non-performing companies is zero. In their model, firms' losses are also not contemporaneously offset by government transfers. Therefore, elite consumers (fund providers of firms) have to cover their losses and cash shortfalls through further foreign borrowing. The expected government transfers to subsidize firms' losses are thus accumulated as the government's expected contingent liabilities. Second, it can be assumed that there is an expectation of government subsidies or tax incentives to all firms, but transfers are not contemporaneously made in each period. Thus, firms have to finance their cash shortfalls, if any, through additional bank borrowing or securities issuance, and the expected transfers from the government to firms are accumulated as the government's expected liabilities. Third, government subsidies or tax incentives can be assumed to be contemporaneously provided to firms in each period. Hence, there is no accumulation of the expected government transfers to firms.

In this model, government subsidies or tax incentives are contemporaneously provided to firms in each period according to the third approach for the following reasons. First, in several countries, government subsidies or tax incentives are provided to firms on a period-by-period basis. Second, unlike Corsetti et al. (1999b), which focus on the moral hazard problem at the corporate level, the banking sector is explicitly incorporated, and its role as the main foreign borrower and major loan provider for the corporate sector is emphasized in this model. If the moral hazard problem at the corporate level is modeled according to the first approach, banks' non-performing loans (NPLs) are expected to be zero since the government will finally bail out those low-type, unprofitable firms. In reality, this is not the case as banks' accumulation of NPL losses plays a key role in triggering and 
aggravating a crisis. Following the idea of Dekle and Kletzer (2005), the moral hazard problem at the bank level is added. That is, given an expected government bailout and inadequate bank monitoring, banks have an incentive to accumulate losses from NPLs. Besides, banks in this model can borrow from abroad, unlike those in the model of Dekle and Kletzer (2005). Hence, they will finance their losses or cash shortfalls through additional foreign borrowing.

In addition, the moral hazard problems at the international level are explicitly modeled here through the determination of an interest rate for banks' foreign borrowing and an exchange rate. Presumptions by foreign investors that government guarantees for corporate and financial investment exist and that the government is committed to a stable exchange rate causes them to underestimate the risks associated with their lending to the domestic banking sector. Foreign investors therefore do not charge an interest rate high enough to compensate for their risks. Moreover, an exchange rate is expected to deviate more from the conventional uncovered interest rate parity when a country adopts a pegged exchange rate regime since investors anticipate that the government will try to maintain a constant exchange rate, regardless of the level of an interest rate differential. Furthermore, a sudden stop of capital flows and a financial crisis can occur in this model when the level of the country's international reserves (a proxy for liquid assets) is below the level of cumulative losses in the banking sector (the expected level of contingent government liabilities). ${ }^{6}$

\subsection{Structure of the Model}

The model considers a bank-based, small open economy with four major sectors: (1) a corporate sector, (2) a banking sector, (3) a household sector, and (4) a public sector (government), which combines fiscal and monetary authorities.

\footnotetext{
${ }^{6}$ Similar to Burnside, Eichenbaum, and Rebelo (2000, 2001b), this emphasizes the role of prospective government deficit in causing a crisis.
} 


\subsubsection{Corporate Sector}

There are $\mathrm{N}$ firms in each period $\mathrm{t}$. Each firm $\mathrm{j}$ is owned by households in a well-diversified portfolio and pays out all its net profits as dividends to its existing shareholders. Each firm $\mathrm{j}$ specializes in the production of traded goods y and has the following production function.

$$
\mathrm{y}_{\mathrm{t}+1}=\mathrm{A}_{\mathrm{t}+1} \mathrm{k}_{\mathrm{t}}^{\alpha} \mathrm{l}_{\mathrm{t}}^{1-\alpha}
$$

$$
\begin{aligned}
& \text { Where } y_{t+1} \quad=\text { Firm } j \text { 's output for period } t+1, \\
& k_{t} \quad=\text { Firm } j \text { 's physical capital at the end of period } t, \\
& A_{t+1} \quad \text { Production technology factor for period } t+1, \text { which is assumed } \\
& \quad \text { to be random and subject to firm type, } \\
& 1_{t} \quad \text { Firm } j \text { 's employed labor at the end of period } t, \\
& \alpha \quad=\text { Income share of capital }(0 \leq \alpha \leq 1) .
\end{aligned}
$$

At the beginning of period $t+1$ (at the end of period $t$ ), each firm $j$ invests $I_{t}^{J}=k_{t}-k_{t-1}+d k_{t-1}$ to produce traded goods $\mathrm{y}_{\mathrm{t}+1}$ and to finance its capital depreciation. The fraction (1-cap) of its new investment (i.e., $\left.\mathrm{k}_{\mathrm{t}}-\mathrm{k}_{\mathrm{t}-1}\right)$ is financed through bank debt $(0 \leq \mathrm{cap} \leq 1)$ while the remaining portion is financed through newly-issued preferred stocks or bonds, which are sold to the household sector. Each firm $\mathrm{j}$ uses its own profits to finance capital depreciation $\left(\mathrm{d} \mathrm{k}_{\mathrm{t}-1}\right)$, where $\mathrm{d}$ is the capital depreciation rate and $0 \leq \mathrm{d} \leq 1$. Banks, new bondholders, and new shareholders demand the same rate of return of $r_{t}^{1}$ from a firm. It is assumed that labor is inelastically supplied, and each firm $j$ pays wages at a rate $\mathrm{W}_{\mathrm{t}}$ per one unit of labor.

There are 2 types of firms in each period $\mathrm{t}+1$. Ex ante each firm does not know its type $\left(A_{t+1}\right)$. The fraction $\left(1-N P L_{t}\right)$ of the firms is high-type with production technology $A+u_{t+1}$, and the remaining fraction $\mathrm{NPL}_{t}$ is low-type with production technology $\mathrm{A}-\mathrm{w}_{\mathrm{t}+1}$. Those low-type firms are not able to pay interest on debt. Assume that $\left(1-\mathrm{NPL}_{t}\right) \mathrm{u}_{\mathrm{t}+1}-\left(\mathrm{NPL}_{\mathrm{t}}\right) \mathrm{w}_{\mathrm{t}+1}=0, \mathrm{~A}>\mathrm{u}_{\mathrm{t}+1}>\mathrm{w}_{\mathrm{t}+1}>0$ and $0 \leq \mathrm{NPL}_{\mathrm{t}} \leq 1$. Hence, $\mathrm{E}_{\mathrm{t}}\left(\mathrm{A}_{\mathrm{t}+1}\right)=\mathrm{A}$ and $\mathrm{E}_{\mathrm{t}}\left[\mathrm{y}_{\mathrm{t}+1}\right]=\mathrm{Ak}_{\mathrm{t}}^{\alpha} 1_{\mathrm{t}}^{1-\alpha}$ 
In addition, firms may have to pay taxes to the government. To promote investment, the government may provide subsidies or tax incentives to firms. The expected value of net transfers to/from the government is equal to $E_{t}\left(s_{t+1}\right)=n k_{t}^{\alpha} 1_{t}^{1-\alpha}$, where $n$ could either be positive (subsidies) or negative (taxes).

Assuming that firm j's expected profits are based on its long-run average amount of employed labor, at the beginning of period $t+1$ (at the end of period $t$ ), each firm $\mathrm{j}$ chooses the level of capital stock $\left(\mathrm{k}_{\mathrm{t}}\right)$ to maximize its expected profits for period $\mathrm{t}+1\left(\pi^{\mathrm{F}}{ }_{\mathrm{t}+1}\right)$.

$$
\begin{aligned}
\pi^{\mathrm{F}}{ }_{\mathrm{t}+1}= & \text { Expected[Output }+ \text { Subsidies }(- \text { Taxes })-\text { Wages }- \text { Interest payments } \\
& \quad-\text { Capital depreciation expenses }] \\
= & \mathrm{E}_{\mathrm{t}}^{\mathrm{j}}\left\lfloor\mathrm{y}_{\mathrm{t}+1}+\mathrm{s}_{\mathrm{t}+1}-\mathrm{W}_{\mathrm{t}} \overline{\mathrm{l}}-\mathrm{r}_{\mathrm{t}}^{1} \mathrm{k}_{\mathrm{t}}-\mathrm{d} \cdot \mathrm{k}_{\mathrm{t}}\right\rfloor \\
= & \mathrm{A} \mathrm{k}_{\mathrm{t}}^{\alpha} \overline{1}^{1-\alpha}+\mathrm{nk}_{\mathrm{t}}^{\alpha} \overline{1}^{1-\alpha}-\mathrm{W}_{\mathrm{t}} \overline{1}-(1-\mathrm{NPL}) \cdot \mathrm{r}_{\mathrm{t}}^{1} \mathrm{k}_{\mathrm{t}}-\mathrm{d} \cdot \mathrm{k}_{\mathrm{t}}
\end{aligned}
$$

subject to

$$
\begin{aligned}
& \mathrm{I}_{\mathrm{t}}^{\mathrm{j}}=\left(\mathrm{k}_{\mathrm{t}}-\mathrm{k}_{\mathrm{t}-1}\right)+\mathrm{d} \cdot \mathrm{k}_{\mathrm{t}-1}(\text { Total investment }=\text { New investment }+ \text { Capital depreciation })(\mathrm{F} 3), \\
& \mathrm{k}_{\mathrm{t}}=\mathrm{e}_{\mathrm{t}}^{\mathrm{j}}+\mathrm{cap} \cdot \mathrm{k}_{t}(\text { Uses of capital }=\text { Sources of capital } \\
&=\text { Bank debt }+ \text { Newly-issued bonds or stocks })
\end{aligned}
$$

where $E_{t}^{j}\left[y_{t+1}\right]=A k_{t}^{\alpha} \overline{1}^{1-\alpha}=$ Firm $j$ 's expected output for period $t+1$,

$E_{t}^{\mathrm{j}}\left[\mathrm{s}_{\mathrm{t}+1}\right]=\mathrm{nk}_{\mathrm{t}}^{\alpha} \overline{1}^{1-\alpha}=$ Firm $\mathrm{j}$ 's expected subsidies or taxes for period $\mathrm{t}+1$,

$\mathrm{E}_{\mathrm{t}}^{\mathrm{j}}\left[\mathrm{W}_{\mathrm{t}} \overline{\mathrm{l}}\right]=\mathrm{W}_{\mathrm{t}} \overline{\mathrm{l}}=$ Firm $\mathrm{j}$ 's expected wages paid to its labor in period $\mathrm{t}+1$,

$E_{t}^{j}\left[r_{t}^{1} k_{t}\right]=\left(1-N P L_{t}\right) \cdot r_{t}^{1} k_{t}=$ Firm j's expected interest payments for period $t+1$,

$\mathrm{E}_{\mathrm{t}}^{\mathrm{j}}\left[\mathrm{d} \cdot \mathrm{k}_{\mathrm{t}}\right]=\mathrm{d} \cdot \mathrm{k}_{\mathrm{t}}=$ Firm $\mathrm{j}$ 's expected capital depreciation expenses in period $\mathrm{t}+1$,

$\mathrm{k}_{\mathrm{t}}=$ Firm j's level of capital stock at the end of period $\mathrm{t}$,

$\mathrm{e}_{\mathrm{t}}^{\mathrm{j}}=\left(1\right.$-cap) $\mathrm{k}_{\mathrm{t}}=$ Firm j's bank debt at the end of period $\mathrm{t}$, 
cap $\cdot \mathrm{k}_{\mathrm{t}}=$ Firm $\mathrm{j}$ 's cumulative amount of newly-issued bonds or stocks at the end of period $t$, $\mathrm{W}_{\mathrm{t}}=$ Wage rate used for period $\mathrm{t}+1$, $\overline{1}=$ Long-run average amount of employed labor, $r_{t}^{1}=$ Rate of return required by banks and new bond/shareholders for period $t+1$, $\mathrm{I}_{\mathrm{t}}^{\mathrm{j}}=$ Firm j's investment, $\mathrm{A}=$ Average production technology factor, $\mathrm{n}=$ Firm j's additional revenue or cost factor due to government subsidies or taxes, $\mathrm{d}=$ Capital depreciation rate $(0 \leq \mathrm{d} \leq 1)$, cap $=$ Fraction of firm j's investment financed by capital markets, $\mathrm{NPL}_{\mathrm{t}}=$ Fraction of low-type firms at the end of period $\mathrm{t}$.

Based on the above setup, the optimal level of capital stock (by rearranging the first order condition with respect to $\mathrm{k}_{\mathrm{t}}$ ) of each firm equals

$$
\mathrm{k}_{\mathrm{t}}=\mathrm{i}\left(\frac{\alpha(\mathrm{A}+\mathrm{n})}{\left(1-\mathrm{NPL}_{\mathrm{t}}\right) \mathrm{r}_{\mathrm{t}}^{1}+\mathrm{d}}\right)^{\frac{1}{1-\alpha}}
$$

The optimal level of capital stock is increasing with parameter $\mathrm{n}$, which measures the level of government subsidies (or taxes if negative). The higher the level of government subsidies or tax incentives (or lower taxes), the higher the firm's expected profits and the greater the incentive for the firm to overinvest. Hence, parameter $\mathrm{n}$ can be used as a measure of the degree of overinvestment or the moral hazard problem at the corporate level. However, since the output is increasing with the level of capital stock $\left(\mathrm{y}_{\mathrm{t}+1}=\mathrm{A}_{\mathrm{t}+1} \mathrm{k}_{\mathrm{t}}^{\alpha} \mathrm{l}_{\mathrm{t}}^{1-\alpha}\right)$, the higher degree of overinvestment, as a result of the higher level of government subsidies or tax incentives, also brings about higher output. It can also be seen that the optimal level of capital stock is decreasing with the rate of return demanded by banks 
and bond/shareholders $\left(\mathrm{r}_{\mathrm{t}}^{1}\right)$. Hence, the interest rate plays a key role in influencing the firm's investment decision in this model.

\subsubsection{Banking Sector}

Suppose that there are M identical banks. Each bank i receives deposits $\left(\mathrm{a}_{\mathrm{t}}^{\mathrm{i}}\right)$ in local currency (LC) real terms from households and borrows $\left(\mathrm{b}_{\mathrm{t}}^{\mathrm{i}}\right)$ in foreign currency (FC) nominal terms from foreign creditors. It pays a real deposit rate of $r_{t}$ to depositors and a nominal foreign borrowing rate of $\mathrm{i}^{\mathrm{b}}$ to foreign creditors.

$$
\text { The weighted average cost of funds for each bank }\left(\mathrm{r}_{t}^{\mathrm{c}}\right)=\frac{\mathrm{r}_{\mathrm{t}} \mathrm{a}_{\mathrm{t}}^{\mathrm{i}}+\mathrm{i}_{\mathrm{t}}^{\mathrm{b}} \frac{\varepsilon_{\mathrm{t}}}{\mathrm{P}_{\mathrm{t}}} \mathrm{b}_{\mathrm{t}}^{\mathrm{i}}}{\mathrm{a}_{\mathrm{t}}^{\mathrm{i}}+\frac{\varepsilon_{\mathrm{t}}}{\mathrm{P}_{\mathrm{t}}} \mathrm{b}_{\mathrm{t}}^{\mathrm{i}}} \text {. }
$$

Each bank i lends its money in LC real terms $\left(\mathrm{e}_{\mathrm{t}}^{\mathrm{i}}\right)$ to the corporate sector and charges a lending rate of $r_{t}^{1}$. Only high-type firms (the fraction $1-N P L_{t}$ of the firms) can pay interest on bank debt in each period t. In addition, each bank has operating expenses of $\mathrm{o}_{\mathrm{t}}$, which are assumed to be mainly employee salaries. Assume that $\mathrm{o}_{\mathrm{t}}=\xi \mathrm{e}_{\mathrm{t}}^{\mathrm{i}}$, where $\xi$ is the operating expense factor and $\xi \geq 0$.

In this model, the bank's nominal foreign borrowing rate $\left(\mathrm{i}_{\mathrm{t}}^{\mathrm{b}}\right)$ is a function of the world nominal interest rate and the aggregate level of banks' net foreign borrowing, i.e.,

$$
\mathrm{i}_{\mathrm{t}}^{\mathrm{b}}=\psi_{0} \mathrm{i}_{\mathrm{t}}^{\mathrm{w}}+\psi_{1}\left(\mathrm{~b}_{\mathrm{t}}-\hat{\mathrm{b}}\right)
$$

Where $i_{t}^{w}=$ World nominal interest rate for period $t+1$,

$b_{t}=$ Aggregate level of banks' net foreign borrowing at the end of period $t$, $\psi_{0}=$ Interest rate sensitivity to the world interest rate, $\psi_{1}=$ Interest rate sensitivity to the aggregate level of banks' net foreign borrowing, $\hat{b}=$ Perceived optimal level of aggregate banks' net foreign borrowing. 
The benefits of modeling the foreign borrowing rate this way are twofold. First, parameter $\psi_{1}$, which is expected to be greater than or equal to zero, reflects how much higher the rate of return foreign creditors need to compensate for their higher risks from a greater amount of lending to the banking sector in another country. Hence, parameter $\psi_{1}$ can be used as a measure of the degree of a moral hazard problem at the international level. When this moral hazard problem is severe, foreign creditors underestimate the risks from their lending to the banking sector and do not fully incorporate those risks into their required rate of return, and thus the value of parameter $\psi_{1}$ is low. As mentioned earlier, this could happen when foreign creditors believe that government guarantees exist. ${ }^{7}$ There could be an extreme case in which foreign creditors strongly believe that the government guarantees will cover the whole amount of credit they have granted to the banking sector in another country. They therefore do not take into account the higher risks from the greater amount of their lending to the banking sector in such a country and demand the same low rate of return, regardless of the level of banks' net foreign borrowing. Parameter $\psi_{1}$ in this extreme case will be equal or close to zero. Second, this is one way to induce stationarity to a small open economy model according to SchmittGrohe and Uribe (2003). Particularly, when $\psi_{1}$ is greater than zero, domestic interest rates serve as an adjustment and transmission mechanism through which any shock affecting the level of banks' net foreign borrowing will have an impact on firms' investment decision and households' saving decision.

Each bank i is owned by households in a well-diversified portfolio and may choose to pay dividends to its shareholders in each period t. When banks are not adequately monitored and when there is a widely held perception that government guarantees exist, it is optimal for banks to maintain minimal loan loss reserves and to pay out their profits from performing loans (PLs) (or high-type

\footnotetext{
${ }^{7}$ An alternative story as proposed by Giannetti (2007) could be an information asymmetry problem. In this model, foreign creditors do not know the quality of bank assets. Hence, they initially lend to banks at a low interest rate. This enables insolvent banks to accumulate bad loans. In equilibrium, when a substantial amount of losses have been accumulated, solvent banks do not find it any longer optimal to issue debt at the interest rates that would compensate investors for risks. Foreign investors anticipate this and stop lending to banks.
} 
firms) as dividends $\left(\mathrm{X}_{\mathrm{t}}^{\mathrm{i}}\right)$ to their shareholders. This creates another layer of moral hazard at the bank level. Assume that each bank maintains the fraction $v(0 \leq v \leq 1)$ of its profits from PLs as provisions against its losses from non-performing loans (NPLs). Dividends paid by each bank i are thus equal to the fraction (1-v) of its profits from PLs, i.e.,

$$
\begin{aligned}
X_{t}^{i} & =(1-v)(\text { Profits from PLs) } \\
& =(1-v)(\text { The total amount of PLs) (Profit per one unit of PL) } \\
& =(1-v)\left(1-\mathrm{NPL}_{t-1}\right) \mathrm{e}_{\mathrm{t}-1}^{\mathrm{i}}\left[\mathrm{r}_{\mathrm{t}-1}^{1}-\left(\mathrm{r}_{\mathrm{t}-1}^{\mathrm{c}}+\xi\right)\right]
\end{aligned}
$$

Since the losses from NPLs are not contemporaneously offset by government transfers, each bank may not have sufficient cash to both finance its NPL losses and pay dividends. It therefore has to cover its losses or cash shortfalls through additional foreign borrowing. Let $\mathrm{F}_{\mathrm{t}}^{\mathrm{i}}$ be the level of bank i's cumulative NPL losses or cash shortfalls, which evolves as

$$
\mathrm{F}_{\mathrm{t}}^{\mathrm{i}}=\left(1+\mathrm{r}_{\mathrm{t}-1}^{\mathrm{c}}\right) \mathrm{F}_{\mathrm{t}-1}^{\mathrm{i}}+\mathrm{X}_{\mathrm{t}}^{\mathrm{i}}
$$

Given the fact that several emerging countries adopted rigid exchange rate regimes before their crises, it is reasonable to first assume that each bank i expects the government to maintain a stable exchange rate and thus does not hedge the foreign exchange (FX) risk associated with its foreign borrowing. ${ }^{8}$ Thus, in each period t, bank i will incur FX profits or losses from its net foreign borrowing of the amount

$$
\mathrm{FX}_{\mathrm{t}}^{\mathrm{i}}=\left(\frac{\varepsilon_{\mathrm{t}}}{\mathrm{P}_{\mathrm{t}}}-\frac{\varepsilon_{\mathrm{t}-1}}{\mathrm{P}_{\mathrm{t}-1}}\right)\left(1+\mathrm{i}_{\mathrm{t}-1}^{\mathrm{b}}\right) \mathrm{b}_{\mathrm{t}-1}^{\mathrm{i}}
$$

Let $\mathrm{AFX}_{\mathrm{t}}^{\mathrm{i}}$ be the level of bank i's cumulative FX profits or losses, which evolves as

$$
\operatorname{AFX}_{t}^{i}=\left(1+r_{t-1}^{c}\right) A F X_{t-1}^{i}+F X_{t}^{i}
$$

\footnotetext{
${ }^{8}$ The model can be extended by relaxing this assumption. By doing so, a bank's FX hedging will influence the bank's decision on interest rates and will affect the level of the bank's cumulative FX profits or losses.
} 
Since there is a widely held perception that government guarantees exist and that the government is committed to a stable exchange rate, principal and interest of banks' foreign debt are assumed to be rolled over by foreign creditors every period as long as the level of the country's international reserves is higher than the expected level of contingent government liabilities.

Based on information at the end of period $t$, each bank $i$ chooses the deposit amount $\left(a_{t}{ }^{i}\right)$, the foreign borrowing amount $\left(\mathrm{b}_{\mathrm{t}}^{\mathrm{i}}\right)$, and the lending amount $\left(\mathrm{e}_{\mathrm{t}}^{\mathrm{i}}\right)$ to maximize its expected profits for period $t+1\left(\pi^{B}{ }_{t+1}\right)$.

$\pi^{\mathrm{B}}{ }_{\mathrm{t}+1}=$ Interest received from PLs - Interest paid to depositors

- Interest paid to foreign creditors - Operating expenses

$$
=\left(1-N P L_{t}\right) r_{t}^{1} e_{t}^{i}-r_{t} a_{t}^{i}-i_{t}^{b}\left(\frac{\varepsilon_{t}}{P_{t}}\right) b_{t}^{i}-\xi e_{t}^{i}
$$

subject to

$$
e_{t}^{i}-e_{t-1}^{i}=a_{t}^{i}-a_{t-1}^{i}+\frac{\varepsilon_{t}}{P_{t}} b_{t}^{i}-\frac{\varepsilon_{t}}{P_{t}} b_{t-1}^{i}+\left(1-N P L_{t-1}\right) r_{t-1}^{1} e_{t-1}^{i}-r_{t-1}^{i} a_{t-1}^{i}-i_{t-1}^{b}\left(\frac{\varepsilon_{t}}{P_{t}}\right) b_{t-1}^{i}-\xi e_{t-1}^{i}-X_{t}^{i}
$$

( $\Delta$ Lending from the end of $\mathrm{t}-1$ to the end of $\mathrm{t}=\Delta$ Deposits $+\Delta$ Net foreign borrowing

+ Actual net income for period $\mathrm{t}$ - Dividends paid to shareholders)

$$
e_{t}^{i}=a_{t}^{i}+\left(\frac{\varepsilon_{t}}{P_{t}}\right) b_{t}^{i}-A F X_{t}^{i}-F_{t}^{i}
$$

(Lending at the end of $\mathrm{t}=$ Deposits + Net foreign borrowing

- Cumulative FX profits or losses - Cumulative NPL losses or cash shortfalls) (B8),

where $e_{t}^{i}=$ Bank i's lending to the corporate sector at the end of period $t$,

$\mathrm{a}_{\mathrm{t}}^{\mathrm{i}}=$ Bank i's deposits at the end of period $\mathrm{t}$,

$\mathrm{b}_{\mathrm{t}}^{\mathrm{i}}=$ Bank i's net foreign borrowing at the end of period $\mathrm{t}$,

$\mathrm{NPL}_{\mathrm{t}}=$ Fraction of low-type firms

$=$ NPLs to total loans ratio at the end of period $\mathrm{t}$,

$r_{t}^{1}=$ Real lending rate for period $t+1$, 
$r_{t}=$ Real deposit rate for period $t+1$,

$\mathrm{i}_{\mathrm{t}}^{\mathrm{b}}=\psi_{0} \mathrm{i}_{\mathrm{t}}^{\mathrm{w}}+\psi_{1}\left(\mathrm{~b}_{\mathrm{t}}-\hat{\mathrm{b}}\right)=$ Nominal foreign borrowing rate for period $\mathrm{t}+1$,

$\xi \mathrm{e}_{\mathrm{t}}^{\mathrm{i}}=$ Bank i's operating expenses for period $\mathrm{t}+1$ ( $\xi=$ operating expense factor),

$\left(\frac{\varepsilon_{t}}{P_{t}}\right)=$ Real exchange rate at the end of period $t$

$=$ Nominal exchange rate divided by price level,

$\mathrm{X}_{\mathrm{t}}^{\mathrm{i}}=$ Dividends paid by bank $\mathrm{i}$ to its shareholders in period $\mathrm{t}$ (equation B2),

$\mathrm{F}_{\mathrm{t}}^{\mathrm{i}}=$ Bank i's cumulative NPL losses at the end of period $\mathrm{t}$ (equation B3),

$\mathrm{FX}_{\mathrm{t}}^{\mathrm{i}}=$ Bank i's FX profits or losses in period $\mathrm{t}$ (equation B4),

$\mathrm{AFX}_{\mathrm{t}}^{\mathrm{i}}=$ Bank i's cumulative FX profits or losses at the end of period $t$ (equation B5).

By rearranging the first order conditions with respect to $a_{t}^{i}$ and $b_{t}^{i}$, the optimal lending rate equals

$$
r_{t}^{1}=\left(\frac{1}{1-N^{\prime}}\right)\left(r_{t}+\xi\right)
$$

and the optimal deposit rate is equal to the optimal foreign borrowing rate, i.e.,

$$
r_{t}=i_{t}^{b}=r_{t}^{c}=\psi_{0} i_{t}^{w}+\psi_{1}\left(b_{t}-\hat{b}\right)
$$

Equations (B9) and (B10) suggest that in equilibrium each bank determines the deposit rate to be equal to the foreign borrowing rate required by foreign creditors and sets the lending rate just to make enough profits from PLs to cover losses from NPLs. Also, the domestic interest rates, both the lending and deposit rates, are increasing with the aggregate level of banks' net foreign borrowing and thus serve as an adjustment mechanism in this model. Hence, if $\psi_{1}$ is sufficiently high, the domestic interest rates will significantly increase during a boom, when the level of investment and banks' foreign borrowing is high, thereby causing firms to lower their investment and inducing households to deposit more money in banks. 
Note that in equilibrium each bank sets its interest rates just to earn enough profits from PLs to cover losses from NPLs. Hence, its profits from PLs are exactly equal to its losses from NPLs. By paying dividends to its shareholders when its expected profits are zero, in each period $t$, each bank accumulates NPL losses on its account of the amount equal to the dividends paid to its shareholders, i.e.,

$$
\begin{aligned}
X_{t}^{\mathrm{i}} & =(1-v)(\text { Profits from PLs })=(1-v)(\text { Losses from NPLs }) \\
& =(1-v)(\text { The total amount of NPLs) (Loss per one unit of NPL) } \\
& =(1-v)\left(\mathrm{NPL}_{t-1}\right) \mathrm{e}_{\mathrm{t}-1}^{\mathrm{i}}\left(\mathrm{r}_{\mathrm{t}-1}^{\mathrm{c}}+\xi\right)
\end{aligned}
$$

According to equation (B11), parameter v, i.e., the loan loss provisioning ratio, determines the level of dividends each bank pays to its shareholders as well as the amount of NPL losses each bank accumulates in each period. Thus, parameter $v$ can be used as a measure of the degree of the moral hazard at the bank level. The lower the value of $v$, the higher the dividends each bank pays to its shareholders, the higher the level of the bank's cumulative NPL losses, and the more severe the moral hazard problem at the bank level.

\subsubsection{Household Sector}

Assume that all households are identical. They work in corporations or banks and have preferences over consumption and money holdings. They hold the entire stock of domestic money balances and own both firms and banks in a well-diversified portfolio. Other than using their money for consumption and money holdings, households invest part of their savings, cap $\cdot\left(\mathrm{K}_{\mathrm{t}}-\mathrm{K}_{\mathrm{t}-1}\right)$ where $0 \leq$ cap $\leq 1$, in newly-issued corporate bonds or stocks, which give them a rate of return of $\mathbf{r}_{t}^{1}$, and deposit the rest in banks, which give them a rate of return of $r_{t}\left(\leq r_{t}^{1}\right)$. Hence, in each period t, households receive income from the corporate sector in the form of wages, bond or stock returns from previous period's investment, and dividends. They also receive income from the banking sector in the form of salaries, interest on deposits, and dividends. All household income, except interest on 
deposits, is taxable. Using the most updated information they receive in period $t$, households decide on how to spend their income. Particularly they choose the paths of consumption $\left(\mathrm{C}_{\mathrm{s}}\right)$, money holdings $\left(\mathrm{M}_{\mathrm{s}}\right)$, and deposits $\left(\mathrm{a}_{\mathrm{s}}\right)$ to maximize their expected utility,

$$
\mathrm{E}_{\mathrm{t}}\left\langle\sum_{\mathrm{s}=\mathrm{t}+1}^{\infty} \frac{1}{(1+\delta)^{\mathrm{s}-(\mathrm{t}+1)}}\left[\ln \left(\mathrm{C}_{\mathrm{s}}\right)+\chi \ln \left(\mathrm{M}_{\mathrm{s}} / \mathrm{P}_{\mathrm{s}}\right)\right]\right\rangle
$$

subject to

$\mathrm{a}_{\mathrm{s}}-\mathrm{a}_{\mathrm{s}-1}=\mathrm{r}_{\mathrm{s}-1} \mathrm{a}_{\mathrm{s}-1}+(1-\eta)\left(\mathrm{Y}_{\mathrm{s}}+\mathrm{S}_{\mathrm{s}}-\mathrm{d} \cdot \mathrm{K}_{\mathrm{s}-1}-\mathrm{r}_{\mathrm{s}-1}(1-\mathrm{cap}) \mathrm{K}_{\mathrm{s}-1}+\mathrm{X}_{\mathrm{s}}\right)-\mathrm{C}_{\mathrm{s}}-\frac{\mathrm{M}_{\mathrm{s}}-\mathrm{M}_{\mathrm{s}-1}}{\mathrm{P}_{\mathrm{s}}}-\mathrm{cap} \cdot\left(\mathrm{K}_{\mathrm{s}}-\mathrm{K}_{\mathrm{s}-1}\right), \forall \mathrm{s}$

$(\Delta$ Deposit balances $=$ Non-taxable income + Taxable income - Consumption

$-\Delta$ Money balances in real terms - Investment in newly-issued corporate bonds or stocks) $(\mathrm{H} 2)$,

$\lim _{s \rightarrow \infty}\left\{\prod_{k=t+1}^{s-1}\left(\frac{1}{1+r_{k}}\right) \cdot\right\} a_{s}=0 \quad$ (Transversality condition)

where $\mathrm{C}_{\mathrm{s}}=$ Aggregate consumption in period s,

$\mathrm{M}_{\mathrm{s}}=$ Aggregate demand for money holdings (monetary aggregate or money balances)

at the end of period $\mathrm{s}$,

$\mathrm{a}_{\mathrm{s}}=$ Aggregate supply of household deposits with banks at the end of period $\mathrm{s}$,

$\mathrm{r}_{\mathrm{s}-1} \mathrm{a}_{\mathrm{s}-1}=$ Interest on deposits for period s which are assumed to be tax exempted,

$\eta=$ Personal income tax rate,

$\mathrm{Y}_{\mathrm{s}}+\mathrm{S}_{\mathrm{s}}-\mathrm{d} \mathrm{K}_{\mathrm{s}-1}-\mathrm{r}_{\mathrm{s}-1}(1-\mathrm{cap}) \mathrm{K}_{\mathrm{s}-1}+\mathrm{X}_{\mathrm{s}}=$ Total taxable income from the corporate sector in

the form of wages, bond or stock returns, and dividends as well as from the banking sector in the form of salaries and dividends for period $\mathrm{s},{ }^{9}$

cap $\cdot\left(\mathrm{K}_{\mathrm{s}}-\mathrm{K}_{\mathrm{s}-1}\right)=$ Investment in newly-issued corporate bonds or stocks in period $\mathrm{s}$,

\footnotetext{
${ }^{9}$ Sum of wages, bond or stock returns, and dividends paid by the corporate sector to the household sector $=\mathrm{Y}_{\mathrm{s}}+\mathrm{S}_{\mathrm{s}}-\mathrm{d} \mathrm{K}_{\mathrm{s}-1}-\left(1-\mathrm{NPL}_{\mathrm{s}-1}\right) \mathrm{r}_{\mathrm{s}-1}^{1}(1-\mathrm{cap}) \mathrm{K}_{\mathrm{s}-1}$

Banks' operating expenses are mainly employee salaries paid to the household sector $=\xi \mathrm{e}_{\mathrm{s}-1}=\xi(1-\operatorname{cap}) \mathrm{K}_{\mathrm{s}-1}$

Total dividends paid by the banking sector $=\mathrm{X}_{\mathrm{s}}$

Hence, total taxable income $=\mathrm{Y}_{\mathrm{s}}+\mathrm{S}_{\mathrm{s}}-\mathrm{d} \mathrm{K}_{\mathrm{s}-1}-\left(\mathrm{r}_{\mathrm{s}-1}+\xi\right)(1-$ cap $) \mathrm{K}_{\mathrm{s}-1}+\xi(1-$ cap $) \mathrm{K}_{\mathrm{s}-1}+\mathrm{X}_{\mathrm{s}}=\mathrm{Y}_{\mathrm{s}}+\mathrm{S}_{\mathrm{s}}-\mathrm{d} \mathrm{K}_{\mathrm{s}-1}-\mathrm{r}_{\mathrm{s}-1}(1-$ cap $) \mathrm{K}_{\mathrm{s}-1}+\mathrm{X}_{\mathrm{s}}$. [since $\mathrm{r}_{\mathrm{s}-1}^{1}=\left(\mathrm{r}_{\mathrm{s}-1}+\xi\right) /\left(1-\mathrm{NPL}_{\mathrm{s}-1}\right)$ according to equations (B9) and (B10)]
} 
$\mathrm{P}_{\mathrm{s}}=$ Domestic price level at the end of period $\mathrm{s}$,

$\chi=$ Preference for money holdings relative to consumption,

$\delta=$ Time preference factor.

According to the first order conditions with respect to $a_{s}$ and $M_{s}$,

$$
\begin{aligned}
& \mathrm{C}_{\mathrm{s}+1}=\left(\frac{1+\mathrm{r}_{\mathrm{s}}}{1+\delta}\right) \mathrm{C}_{\mathrm{s}} \\
& \frac{\mathrm{M}_{\mathrm{s}}}{\mathrm{P}_{\mathrm{s}}}=\frac{\chi \mathrm{C}_{\mathrm{s}}\left(1+\mathrm{i}_{\mathrm{s}}\right)}{\mathrm{i}_{\mathrm{s}}} \text { where }\left(1+\mathrm{i}_{\mathrm{s}}\right)=\left(1+\pi_{\mathrm{s}}\right)\left(1+\mathrm{r}_{\mathrm{s}}\right)
\end{aligned}
$$

the growth rate of consumption $\left(\mathrm{C}_{\mathrm{s}+1} / \mathrm{C}_{\mathrm{s}}\right)$ is increasing with the domestic real deposit rate $\left(\mathrm{r}_{\mathrm{s}}\right)$. In addition, the real money balances $\left(\mathrm{M}_{\mathrm{s}} / \mathrm{P}_{\mathrm{s}}\right)$ are increasing with consumption $\left(\mathrm{C}_{\mathrm{s}}\right)$, but decreasing with the domestic nominal deposit rate $\left(i_{\mathrm{s}}\right)$. This implies that, when the domestic real deposit rate increases, households consume less today relative to the next period and maintain lower money balances. They instead deposit more money in banks to earn the higher rate of return. Hence, the domestic deposit rate plays a key role in influencing households' decisions on consumption, money holdings, as well as the amount of their deposits with banks.

\subsubsection{Public Sector}

The public sector comprises fiscal and monetary authorities. It manages the stock of international reserves and implements fiscal and monetary policies. The domestic public sector can borrow from and lend in domestic and international financial markets at a rate of $r_{t}$ and never defaults on its domestic and foreign liabilities. Assuming that fiscal policies are exogenous ${ }^{10}$ and the following modified uncovered interest rate parity (UIP) holds,

$$
\mathrm{E}_{\mathrm{t}}\left[\frac{\varepsilon_{\mathrm{t}+1}}{\varepsilon_{\mathrm{t}}}\right]=\left(1+\mathrm{P}_{\varepsilon}\right)\left(\frac{\varepsilon_{\mathrm{t}+1}}{\varepsilon_{\mathrm{t}}}\right)=\frac{\left(1+\mathrm{i}_{\mathrm{t}}\right)}{\left(1+\mathrm{i}_{\mathrm{t}}^{\mathrm{w}}\right)}
$$

where $\mathrm{P}_{\varepsilon}=$ Expected exchange rate deviation from conventional UIP,

\footnotetext{
${ }^{10}$ Personal income tax rate $(\eta)$ and government subsidies or taxes to the corporate sector are fixed, and government spending is exogenous.
} 
$\mathrm{i}_{\mathrm{t}}^{\mathrm{w}}=$ World nominal interest rate for period $\mathrm{t}+1$,

$\mathrm{i}_{\mathrm{t}}=$ Domestic nominal deposit rate for period $\mathrm{t}+1=\left(1+\pi_{\mathrm{t}}\right)\left(1+\mathrm{r}_{\mathrm{t}}\right)-1$,

$\varepsilon_{\mathrm{t}}=$ Nominal exchange rate (domestic currency per one unit of foreign currency) at the end of period $t$.

According to equation (MU), when $\mathrm{P}_{\varepsilon}=0$, the exchange rate is entirely determined by the interest rate differential, i.e., the UIP exactly holds. Hence, parameter $\mathrm{P}_{\varepsilon}$ measures the expectations of market participants on how much the exchange rate will deviate from the conventional UIP, another moral hazard problem at the international level. When $\mathrm{P}_{\varepsilon}>0\left(\mathrm{P}_{\varepsilon}<0\right)$, it is expected that the local currency will be worth more (less) than the value based on the conventional UIP. The expected exchange rate deviation from the conventional UIP (i.e., the absolute value of $\mathrm{P}_{\varepsilon}$ ) should be higher in countries adopting rigid exchange rate regimes since their exchange rates will be less responsive to interest rate differentials than those in countries adopting more flexible exchange rate regimes.

The public sector can choose to target either the nominal exchange rate $(\varepsilon)$ or the inflation rate $(\pi)$ to maintain the consolidated public sector budget identity,

$$
\frac{\varepsilon_{t}}{P_{t}}\left(R_{t}-R_{t-1}\right)=T_{t}+\frac{M_{t}-M_{t-1}}{P_{t}}+r_{t-1} \frac{\varepsilon_{t}}{P_{t}} R_{t-1}-G_{t}-S_{t}
$$

$(\Delta$ International reserves $=$ Tax revenues $+\Delta$ Monetary aggregate in real terms

+ Interest on international reserves at the end of the previous period

- Government spending - Government subsidies or taxes to the corporate sector)

(G1),

where $\mathrm{R}_{\mathrm{t}}=$ Country's international reserves at the end of period $\mathrm{t}$,

$T_{t}=$ Revenue from personal income taxes in period $t=\eta\left(Y_{t}+S_{t}-d K_{t-1}-r_{t-1}(1-c a p) K_{t-1}+X_{t}\right)$, $\mathrm{S}_{\mathrm{t}}=$ Government subsidies or taxes to the corporate sector in period $\mathrm{t}=\mathrm{nK}_{\mathrm{t}-1}{ }^{\alpha} \mathrm{L}_{\mathrm{t}-1}{ }^{1-\alpha}$, $\mathrm{G}_{\mathrm{t}}=$ Government spending in period $\mathrm{t}$, $\mathrm{r}_{\mathrm{t}-1}=$ Government borrowing and lending rate $=$ Domestic real deposit rate for period $\mathrm{t}$. 
For the analyses in the following sections, assume that the government of this economy chooses to target the inflation rate. Hence, the inflation rate is exogenous, and the exchange rate is endogenously determined by the model according to equation (MU).

\subsubsection{National Account}

By combining the budget constraints of the four sectors, the economy's resource constraint follows

$$
\begin{gathered}
Y_{t}=I_{t}+C_{t}+G_{t}+N F A_{t}-\left(1+r_{t-1}\right) N F A_{t-1} \\
\text { where } I_{t}=\left(K_{t}-K_{t-1}\right)+d K_{t-1} \\
N A_{t}=\frac{\varepsilon_{t}}{P_{t}}\left[R_{t}-b_{t}\right]=\text { Net foreign assets of the public and private sectors }
\end{gathered}
$$

\subsubsection{Market Clearing Conditions}

In normal times, the markets in this model clear as follows.

Deposits: Banks set the deposit rate and are willing to accept deposits as supplied by the household sector. Therefore, the deposit amount $\left(a_{t}\right)$ is determined by the supply side.

Money: Monetary aggregate $\left(\mathrm{M}_{\mathrm{t}}\right)$ is determined by the demand for money holdings by households, which in fact can be influenced by the government's action through the exchange rate or the inflation rate.

Foreign borrowing: Foreign creditors set the foreign borrowing rate. As long as the level of the country's international reserves exceeds the expected level of the government's contingent liabilities, foreign creditors are willing to supply loans as demanded by the domestic banking sector. Thus, the aggregate level of banks' net foreign borrowing $\left(b_{t}\right)$ is determined by the demand side.

Bank lending to the corporate sector: Banks set the lending rate to cover their costs from granting loans to the corporate sector. As long as they can obtain enough funding from depositors 
and foreign creditors, banks are willing to extend credit as demanded by the corporate sector. Hence, the amount of bank lending to the corporate sector $\left(\mathrm{e}_{\mathrm{t}}\right)$ is determined by the demand side.

In good times, firms are able to obtain funds as much as they want to finance their investment. Clearly, international capital flows via the banking sector serve as an additional source of financing for firms' investment, leading to higher investment and output during a boom. However, with moral hazard problems, more available capital facilitates excessive borrowing and risk-taking behavior of several agents in the economy. With government subsidies or tax incentives, firms invest more than they optimally do without the government subsidies or tax incentives. When banking supervision is lax and a future government bailout is expected, banks are willing to lend excessively to firms as long as they can obtain enough funding from depositors and foreign creditors. Banks also have an incentive to maintain minimal loan loss provisions. With expected government guarantees and stable exchange rates, foreign creditors are willing to lend excessively to the domestic banking sector as long as the expected level of contingent government liabilities does not exceed the level of the country's international reserves. All these factors not only amplify a boom, but also increase the country's vulnerability to a sudden stop of capital flows and a crisis.

\subsection{Sudden Stop Financial Crisis}

This section explains how a 'sudden stop' of international capital flows causes a financial crisis which then spills over to the real economy.

\subsubsection{The Occurrence of a Crisis}

Two key ingredients that cause a sudden stop are banks' accumulation of NPL losses (the moral hazard problem at the bank level) and banks' ability to obtain additional foreign borrowing to meet their cash constraints (the moral hazard problem at the international level). First, banks have an incentive to maintain minimal provisions $(v<1)$ and accumulate NPL losses on the banks' accounts $\left(F_{t}\right)$ when a future government bailout is expected and banking supervision is inadequate. Second, since the losses from NPLs are not contemporaneously offset by government transfers, banks 
have to cover their cash shortfalls through additional foreign borrowing. Given a presumption that government guarantees exist and the government is committed to a stable exchange rate, foreign creditors continue to allow banks to borrow in excess of the banks' credit net of deposits as long as foreign creditors believe that the government can fulfill its future debt obligations. In other words, banks are able to obtain funds from foreign creditors as they demand as long as the level of the country's liquid collateral (the level of international reserves at the beginning of period $\left.t\left(\frac{\varepsilon_{t}}{P_{t}}\right) R_{t-1}\right)$ ) remains above the fraction $\beta$ of the banks' cumulative NPL losses $\left(\mathrm{F}_{\mathrm{t}}\right)$.

When the level of international reserves reaches the threshold $\beta F$, foreign creditors stop rolling over the outstanding stock of credit and do not further extend credit to the domestic banking sector. A sudden stop financial crisis starts in period $t_{c}$ the first time the following sudden stop condition holds.

$$
\left(\frac{\varepsilon_{\mathrm{t}_{\mathrm{c}}}}{\mathrm{P}_{\mathrm{t}_{\mathrm{c}}}}\right) \mathrm{R}_{\mathrm{t}_{\mathrm{c}}-1}<\beta \mathrm{F}_{\mathrm{t}_{\mathrm{c}}} \quad, 0 \leq \beta \leq 1
$$

It can be seen that when banks cannot accumulate NPL losses (when F equals zero), either because banking supervision is effective (no moral hazard problem at the bank level) or banks cannot borrow from abroad in excess of their credit net of deposits (no moral hazard problem at the international level), a sudden stop condition (SS1) will never hold and a crisis will never occur.

Note that although the moral hazard problem at the corporate level is not one of the major factors causing a sudden stop, it could amplify the effect of capital flows. Particularly, government subsidies or tax incentives increase firms' expected profits, causing firms to overinvest and borrow excessively from banks. Overinvestment and excessive bank lending magnify a boom as well as increase crisis costs when a bust comes. 


\subsubsection{The Effect of a Crisis}

When there is a sudden stop, foreign creditors stop rolling over the outstanding stock of credit and do not further extend credit to the domestic banking sector, causing a reduction in bank lending to the corporate sector and an economic contraction as follows.

Foreign borrowing: During a sudden stop, banks can borrow from abroad only up to the point where the level of the country's international reserves can cover the fraction $\beta$ of their cumulative NPL losses, i.e., $\left(\frac{\varepsilon_{t}}{P_{t}}\right) R_{t-1}=\beta \cdot F_{t}$. Hence, the aggregate level of banks' net foreign borrowing is determined by the supply side, which is equal to

$$
\left(\frac{\varepsilon_{t}}{P_{t}}\right) b_{t}=e_{t}-a_{t}+A_{t}+\frac{\frac{\varepsilon_{t}}{P_{t}} R_{t-1}}{\beta}
$$

A discrepancy between the demand for and the supply of foreign borrowing or a credit cut by foreign creditors is equal to $\mathrm{F}_{\mathrm{t}}-\frac{\varepsilon_{\mathrm{t}}}{\mathrm{P}_{\mathrm{t}}}\left(\frac{\mathrm{R}_{\mathrm{t}-1}}{\beta}\right)$. Notice that the higher the fraction of banks' cumulative NPL losses which are expected by foreign creditors to be covered by the country's international reserves $(\beta)$, the higher the credit cut by foreign creditors.

Government bailouts: When there is a sudden stop of capital flows, the government will step in and rescue banks. During such a period, there will be transfers of banks' cumulative NPL losses to the government of the amount $\varphi\left(\mathrm{F}_{\mathrm{t}}-\frac{\varepsilon_{\mathrm{t}}}{\mathrm{P}_{\mathrm{t}}}\left(\frac{\mathrm{R}_{\mathrm{t}-1}}{\beta}\right)\right)$, where $0 \leq \varphi \leq 1$, to partially or fully subsidize banks' cash shortfalls as a result of the credit cut by foreign creditors.

It is also assumed that a bailout plan by the government will start a certain number of periods after the first sudden stop. From the start to the end of the bailout plan (bailout period), there will be a series of transfers of the remaining banks' NPL losses $\left(F_{t}\right)$ to the government to clean up the 
banking system. Banks' bad assets, $\mathrm{F}_{\mathrm{t}}$, will thus be replaced with good assets, GA . All the transfers of bad assets to the government will be booked as government liabilities $\left(\mathrm{L}_{\mathrm{t}}^{\mathrm{f}}\right)$, and the government will have to find ways to gradually finance such liabilities through fiscal or monetary tools.

Bank lending to the corporate sector: If banks only receive partial subsidies from the government $(\varphi<1)$ during a sudden stop, banks have to call their loans and reduce their lending to the corporate sector by the amount $(1-\varphi)\left(\mathrm{F}_{\mathrm{t}}-\frac{\varepsilon_{\mathrm{t}}}{\mathrm{P}_{\mathrm{t}}}\left(\frac{\mathrm{R}_{\mathrm{t}-1}}{\beta}\right)\right)$ to meet their cash constraints. Hence, the level of bank lending to the corporate sector is also determined by the supply side. Firms will therefore receive less credit than what they demand and will have to reduce their investment, causing a reduction in the level of capital stock and output during a sudden stop period.

The costs of a crisis created by international capital flows and moral hazard problems could be substantial. Two types of costs are considered in this model: (1) direct costs (or bailout costs), which includes transfers from the government to the banking sector to subsidize banks' cash shortfalls during sudden stops and transfers of the remaining banks' NPL losses to the government to clean up the banking system during the bailout period, and (2) indirect costs (or output losses), as credit cuts by foreign creditors during sudden stops lead to reductions in bank lending to the corporate sector, investment and thus output. The analysis and the assessment of the direct and indirect costs through the simulation exercises will be discussed in Chapter IX.

\subsection{Analysis of the Model}

The equilibrium conditions derived in sections 4.1 and 4.2 for a bank-based, small open economy based on decentralized (not first best) decision making by each sector are summarized in Appendix A. Appendix B provides the list and descriptions of all parameters and variables. Given the parameter values $\left(\alpha, A, n\right.$, cap, $\left.d, \Psi_{0}, \Psi_{1}, \hat{b}, \xi, \delta, \chi, \eta, P_{\varepsilon}, v, \beta, \varphi\right)$, the initial values $\left(K_{0}, b_{0}, C_{0}\right.$, $\left.\varepsilon_{0} / \mathrm{P}_{0}, \mathrm{R}_{0}, \mathrm{~F}_{0}, \mathrm{AFX}_{0}\right)$, and the paths for exogenous variables $\left(\mathrm{i}^{\mathrm{w}}{ }_{\mathrm{t}}, \pi_{\mathrm{t}}, \mathrm{L}_{\mathrm{t}}, \mathrm{NPL}_{\mathrm{t}}, \mathrm{G}_{\mathrm{t}}\right)$, all the endogenous 
variables $\left(\mathrm{Y}_{\mathrm{t}}, \mathrm{K}_{\mathrm{t}}, \mathrm{I}_{\mathrm{t}}, \mathrm{e}_{\mathrm{t}}, \mathrm{b}_{\mathrm{t}}, \mathrm{a}_{\mathrm{t}}, \mathrm{C}_{\mathrm{t}}, \mathrm{M}_{\mathrm{t}} / \mathrm{P}_{\mathrm{t}}, \varepsilon_{\mathrm{t}} / \mathrm{P}_{\mathrm{t}}, \mathrm{r}_{\mathrm{t}}, \mathrm{r}_{\mathrm{t}}^{\mathrm{t}}, \mathrm{i}_{\mathrm{t}}, \mathrm{S}_{\mathrm{t}}, \mathrm{X}_{\mathrm{t}}, \mathrm{F}_{\mathrm{t}}, \mathrm{FX}_{\mathrm{t}}, \mathrm{AFX}_{\mathrm{t}}, \mathrm{L}_{\mathrm{t}}^{\mathrm{f}}, \mathrm{R}_{\mathrm{t}}, \mathrm{GA}_{\mathrm{t}}\right.$, Transfer $\left.{ }_{\mathrm{t}}\right)$ can be derived using the system of equations in Appendix A.

In this model, an economy is defined to be at a steady state (at an equilibrium point) when there is no change in any of the endogenous variables. Appendix $\mathrm{C}$ presents the steady state solutions for all variables. These steady state conditions can only be achieved when there is no change in any of the exogenous variables and when banks maintain a $100 \%$ loan loss provisioning ratio $(v)$. If the loan loss provisioning ratio is less than $100 \%$, there will be an accumulation of banks' NPL losses $\left(F_{t}\right)$, which needs to be financed through additional foreign borrowing $\left(b_{t}\right)$. $F_{t}$ and $b_{t}$ will continue to increase, and the steady state will never be reached. This issue is further examined using the dynamic analysis.

The dynamic of the economy can be analyzed using two first difference equations, i.e., the change in household consumption $\left(\mathrm{C}_{t}-\mathrm{C}_{\mathrm{t}-1}\right)$ and the change in banks' net foreign borrowing $\left(\mathrm{b}_{\mathrm{t}}-\mathrm{b}_{\mathrm{t}-1}\right)$, after combining thirteen equilibrium conditions in Appendix A.

$$
\begin{aligned}
& C_{t}-C_{t-1}=\left(\frac{1+r_{t-1}}{1+\delta}-1\right) C_{t-1}
\end{aligned}
$$

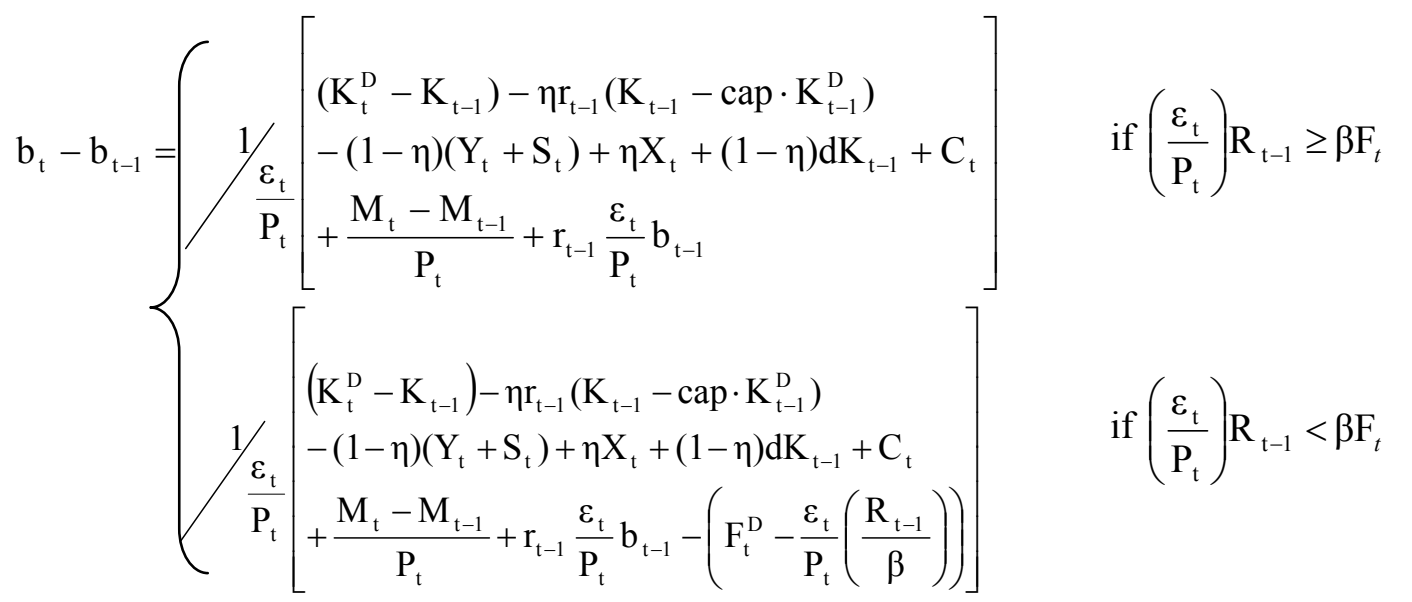

Suppose that everything else is at the steady state level. If banks maintain a loan loss provisioning ratio of less than $100 \%$ at time $t$ (i.e., banks still pay part of their profits from PLs as dividends to their shareholders), the term $\eta X_{t}$ on the right hand side of equation (DIF2_1) is positive, 
while the sum of all other terms is zero, causing the aggregate level of banks' net foreign borrowing $\left(b_{t}\right)$ to increase and move away from its steady state level. ${ }^{11}$ If banks still continue paying dividends to their shareholders in the following periods, the aggregate level of banks' net foreign borrowing as well as the level of banks' cumulative NPL losses $\left(\mathrm{F}_{\mathrm{t}}\right)$ will continue to increase. At some point, the sudden stop condition, $\left(\frac{\varepsilon_{t}}{P_{t}}\right) R_{t-1}<\beta F_{t}$, will be hit. Once the sudden stop condition is reached, foreign creditors will cut their lending to the banking sector by $\left(F_{t}^{D}-\frac{\varepsilon_{t}}{P_{t}}\left(\frac{R_{t-1}}{\beta}\right)\right)$, causing the level of banks' net foreign borrowing to decrease by the same amount (equation (DIF2_2)). After the first sudden stop, if banks still continue to maintain the loan loss provisioning ratio of less than $100 \%$, banks' NPL losses will be accumulated again. The level of banks' net foreign borrowing will therefore increase to finance those losses, and a sudden stop will occur again in the future. Hence, there is no stable path leading to a steady state when the banks' loan loss provisioning ratio is less than $100 \%$.

If banks maintain a loan loss provisioning ratio at $100 \%$ at all times, a sudden stop will never occur and equations (DIF2_1) and (DIF2_2) collapse to one equation,

$$
b_{t}-b_{t-1}=1 / \frac{\varepsilon_{t}}{P_{t}}\left[\begin{array}{l}
\left(K_{t}-K_{t-1}\right)-\eta r_{t-1}(1-c a p) K_{t-1} \\
-(1-\eta)\left(Y_{t}+S_{t}\right)+(1-\eta) d K_{t-1}+C_{t} \\
+\frac{M_{t}-M_{t-1}}{P_{t}}+r_{t-1} \frac{\varepsilon_{t}}{P_{t}} b_{t-1}
\end{array}\right]
$$

Since equations (DIF1) and (DIF2_3) are continuous and differentiable, both of them can be analyzed using their linear approximations around the steady state values of $b_{t}$ and $C_{t}$. Appendix D presents the linear approximations around the steady state values of $b_{t}$ and $C_{t}$, the phase diagram, and the solutions for linearized difference equations (DIF1) and (DIF2_3). The phase diagram suggests that there are

\footnotetext{
${ }^{11} \mathrm{An}$ increase in $b_{t}$ will cause the domestic real deposit rate $\left(r_{t}\right)$ to rise through the interest rate adjustment mechanism, $r_{t}=\psi_{0} i_{t}^{w}+\psi_{1}\left(b_{t}-\hat{b}\right)$. The change in the domestic real deposit rate causes investment, consumption, monetary aggregate, as well as all other endogenous variables to move away from their steady state values.
} 
stable paths leading to a steady state (e.g., PQ and RQ) as well as unstable paths leading to an explosion in this economy. This equilibrium is thus a saddle point where it is stable in some directions, but unstable in others. The general solutions to linearized equations (DIF1) and (DIF2_3) include both stable and unstable paths. However, the unstable paths, the ones in which the eigenvalue is greater than 1 , can be ruled out by imposing an additional condition so that the term containing the unstable eigenvalue is equal to zero.

In sum, the steady state and dynamic analyses of this model suggest that, when banks can accumulate NPL losses (i.e., maintain a loan loss provisioning ratio of less than $100 \%$ ) and borrow from abroad to finance those losses, a sudden stop will surely occur at some point, and there is no stable path leading to a steady state. In contrast, when banks maintain the loan loss provisioning ratio at $100 \%$ at all times, a sudden stop will never occur, and there are some stable paths leading to the equilibrium point. These analyses therefore highlight the role of the moral hazard problems at the bank level (when banks can accumulate NPL losses) and at the international level (when banks can obtain funds from abroad to finance their cash shortfalls) in causing instability in an economy. 


\section{CHAPTER V}

\section{APPLICATION OF THE MODEL}

The model developed in Chapter IV demonstrates a mechanism through which international capital flows are transmitted from the banking sector to the corporate sector. Moreover, it shows how moral hazard problems at all levels, together with international capital flows, fuel a boom as well as cause instability in an economy. In fact, structural and policy distortions are the root causes of those moral hazard problems. With regard to the moral hazard problem at the bank level, banks can maintain minimal loan loss provisions and accumulate non-performing loan losses largely due to ineffective banking supervision. Regarding the moral hazard problem at the corporate level, firms' overinvestment is mainly driven by government policies aiming to promote investment. With regard to the moral hazard problems at the international level, foreign creditors lend excessively to the domestic banking sector without demanding rates of return high enough to compensate for their risks because they believe that government guarantees exist. In addition, foreign creditors expect exchange rates to move less with interest rate differentials since they believe that the government is committed to a stable exchange rate. Hence, changes in the quality of institutions and domestic policies can potentially help reduce moral hazard problems and increase the net benefit of international capital flows to a country.

The following sections apply the model developed in Chapter IV to a bank-based, small open economy, which has experienced a financial crisis and undergone major institutional reforms, to examine two major issues. 
(1) Have there been changes in the quality of institutions and domestic policies, leading to significant reductions in moral hazard problems after a crisis?

(2) What are the impacts of such changes on the net benefit of international capital flows? ${ }^{12}$

The chosen country is Thailand since it is a good example of a bank-based, small open economy, which has experienced both a boom (in the early 1990s) and a bust (the crisis during 19971998). It has gone through major institutional reforms (e.g., the establishment of a deposit insurance agency to replace the blanket guarantee, the enforcement of the New Financial Institutions Act, the banking supervisory policy upgrade, and the change in investment promotion policies), which potentially help reduce moral hazard problems. Thailand is also a good representative of emerging countries. Based on the measures of the degree of openness used by Bekaert et al. (2005) and Bekaert, Harvey, Lundblad and Siegel (2007) (e.g., official equity market openness year, market segmentation measure (LEGO)), Thailand ranks mostly in the middle among all countries as well as among all the emerging countries in the sample. The rankings of Thailand for most of the economic performance and quality of institution measures used by Bekaert et al. (2005) are also in line with other countries. The only exceptions are real GDP growth and judicial efficiency, in which Thailand ranks third among 95 countries and $46^{\text {th }}$ among 47 countries, respectively. Hence, Thailand is not an outliner, and it is a good example of a bank-based, small open economy, to which the model can be applied. The facts about Thailand are further discussed in section 5.3.

To investigate the first issue, the parameters measuring the severity of moral hazard problems for pre-crisis, crisis, and post-crisis periods are estimated using the equilibrium conditions in Appendix A and the GMM approach to fit Thailand data. Section 5.1 explains the parameters of interest. In addition, the hypothesis tests on the estimated parameter values for the pre- and post-

\footnotetext{
${ }^{12}$ Not every crisis country has gone through major institutional reforms. However, these hypotheses are still useful as they can be used to test whether there have been no significant changes in the quality of institutions and domestic policies in those crisis countries.
} 
crisis periods are conducted. If the quality of institutions and domestic policies has been significantly altered and the moral hazard problems have been reduced, the values of the parameters measuring the severity of moral hazard problems for the post-crisis period should be significantly different from those for the pre-crisis period. In particular, those parameter values should indicate a lower degree of moral hazard problems after a crisis. Section 5.2 describes the hypotheses with regard to those parameters. The details about the data, methodology, as well as estimation and hypothesis testing results are presented in Chapter VI, VII, and VIII, respectively

To examine the second issue, the simulation exercises are undertaken to assess the impact of changes in the quality of institutions and domestic policies, as measured by changes in the moral hazard parameters, on the costs and benefits of capital flows to a country like Thailand under different scenarios. Particularly, the direct costs (i.e., bailout costs) and the indirect costs (i.e., output losses) of capital flows under each scenario are analyzed relative to the base scenario to assess the impact of changes in one or more moral hazard parameters on those costs. The details about the simulation exercises and the results are presented in Chapter IX.

\section{$\underline{\text { 5.1 Parameters of Interest }}$}

Since the root cause of the moral hazard problems is the poor quality institutions and domestic policies, the parameters measuring the severity of moral hazard problems can be used as proxies for the quality of institutions and domestic policies.

\section{(1) Loan loss provisioning ratio (v)}

With lax banking supervision and an expected future government bailout, banks have an incentive to pay dividends from their profits from performing loans (PLs) to their shareholders, maintain minimal loan loss provisions against their losses from non-performing loans (NPLs), and accumulate losses from NPLs. Parameter v, which measures the level of banks' loan loss provisions, determines the level of NPL losses that banks can accumulate in each period. Thus, it indicates the 
degree of the moral hazard problem at the bank level and can be used as a proxy for the quality of institutions and policies with respect to banking supervision.

\section{(2) Firms' additional revenue or cost factor due to government subsidies or taxes (n).}

As a way to promote investment in a country, the government provides subsidies or tax incentives to firms. These incentives increase firms' expected profits and induce firms to invest more than they optimally do without the government subsidies or tax incentives, leading to overinvestment. Parameter $\mathrm{n}$, which indicates the level of government subsidies or tax incentives and the degree of overinvestment, measures the degree of the moral hazard problem at the corporate level and can be used as a proxy for the quality of institutions and policies with regard to corporate investment.

\section{(3) Interest rate sensitivity to the aggregate level of banks' net foreign borrowing $\left(\Psi_{1}\right)$}

With presumptions that government guarantees exist, foreign creditors are willing to lend to banks in another country as much as the banks need. Foreign creditors also underestimate the risks associated with their lending to the banking sector in another country. Particularly, although extending more credit to the banking sector in another country exposes foreign creditors to higher risks, they may not fully take into account those risks when determining their rates of return if they believe that government guarantees exist. Parameter $\psi_{1}$, which measures the interest rate sensitivity to the aggregate level of banks' net foreign borrowing, reflects the level of risks that foreign investors perceive and factor into their required rates of return. Hence, parameter $\Psi_{1}$ measures the degree of a moral hazard problem at the international level and the quality of institutions and policies relating to foreign investors' estimation of risks.

(4) Expected exchange rate deviation from the conventional uncovered interest rate parity (UIP) $\left(\mathbf{P}_{\varepsilon}\right)$

In countries with pegged or rigid exchange rate regimes, foreign investors expect the governments of those countries to be committed to stable exchange rates and to intervene in the 
foreign exchange (FX) markets, when there are market forces driving changes in the exchange rates, such as interest rate differentials. Hence, the exchange rates are expected to be less responsive to the interest rate differentials and to deviate more from the conventional uncovered interest rate parity (UIP) in such countries. Parameter $\mathrm{P}_{\varepsilon}$, which measures the expected exchange rate deviation from the conventional UIP, serves as a measure of another moral hazard problem at the international level and a proxy for the quality of institutions and policies with regard to exchange rates.

\section{$\underline{5.2}$ Hypotheses}

As the degree of moral hazard problems is largely determined by the quality of institutions and domestic policies, changes in the quality of institutions and domestic policies can potentially help reduce moral hazard problems and increase the net benefit of international capital flows. The following hypotheses are formed to test whether there have been changes in the quality of institutions and domestic policies in a crisis country, leading to significant reductions in moral hazard problems after a crisis.

\subsubsection{Moral Hazard Problem at the Bank Level}

Hypothesis 1: Before a crisis, banking supervision policies, such as loan classification and loan loss provisioning rules, were typically quite lax and bank monitoring was inadequate. Banks therefore had an incentive to maintain minimal loan loss provisions and to accumulate losses from NPLs, expecting to receive a future government bailout if something bad happened. After a crisis, banking supervision policies in several crisis countries have been upgraded to international standards and become more stringent, resulting in more effective banking supervision. If more effective banking supervision leads to a significantly higher level of banks' loan loss provisions, parameter v, which indicates the banks' loan loss provisioning ratio, should be higher and the moral hazard problem at the bank level should be less severe after a crisis. The specific predictions for the null hypothesis $\left(\mathrm{H}_{0}\right)$ and alternative hypothesis $\left(\mathrm{H}_{\mathrm{A}}\right)$ are 


$$
\begin{aligned}
& \mathrm{H}_{\mathrm{O}}^{1}: v^{\text {before }}=v^{\text {after }}, \\
& \mathrm{H}_{\mathrm{A}}^{1}: v^{\text {before }}<v^{\text {after }} .
\end{aligned}
$$

\subsubsection{Moral Hazard Problem at the Corporate Level}

Hypothesis 2: Firms optimally choose the level of capital stock to maximize their expected profits. However, when firms receive government subsidies or tax privileges, their expected profits are higher, and firms will invest more than when there are no such incentives. This leads to overinvestment and excessive corporate borrowing, which amplify the boom-bust cycle of an economy. After a crisis, a number of countries have tightened their fiscal policies and have revised their investment promotion policies. If such revisions lead to a significant reduction in government subsidies or tax incentives provided to firms, the value of parameter $n$, which indicates the level of government subsidies or tax incentives to the corporate sector, should be lower after a crisis. The specific predictions for $\mathrm{H}_{0}$ and $\mathrm{H}_{\mathrm{A}}$ are

$$
\begin{aligned}
& \mathrm{H}_{\mathrm{O}}^{2}: \mathrm{n}^{\text {before }}=\mathrm{n}^{\text {after }}, \\
& \mathrm{H}_{\mathrm{A}}^{2}: \mathrm{n}^{\text {before }}>\mathrm{n}^{\text {after }} .
\end{aligned}
$$

\subsubsection{Moral Hazard Problems at the International Level}

Hypothesis 3: Before a crisis, there was a widely held perception that government guarantees for corporate and financial investment existed. Foreign creditors therefore underestimated the risks associated with their lending to banks in a crisis country and did not demand rates of return high enough to compensate for their risks. After a crisis, several crisis countries have had a plan to replace the blanket guarantee with a limited guarantee, for example, through the establishment of a deposit insurance agency. If a crisis and a plan to replace the blanket guarantee with a limited guarantee cause foreign creditors to significantly adjust their risk perceptions and demand much higher interest rates to compensate for their higher risks when banks borrow more from them, parameter $\psi_{1}$, which 
measures the interest rate sensitivity to the aggregate level of banks' net foreign borrowing, should be higher after a crisis. The specific predictions for $\mathrm{H}_{0}$ and $\mathrm{H}_{\mathrm{A}}$ are

$$
\begin{aligned}
& \mathrm{H}_{\mathrm{O}}^{3}: \psi_{1}^{\text {before }}=\psi_{1}^{\text {after }}, \\
& \mathrm{H}_{\mathrm{A}}^{3}: \psi_{1}^{\text {before }}<\psi_{1}^{\text {after }} .
\end{aligned}
$$

Hypothesis 4: Many crisis countries adopted rigid exchange rate regimes before a crisis. Under rigid exchange rate regimes, foreign investors believe that the governments of such countries are committed to stable exchange rates and will intervene in the FX markets if there are interest rate differentials which may cause changes in the exchange rates. In other words, they expect the exchange rates in countries adopting rigid exchange rate regimes to respond less to interest rate differentials and deviate more from the conventional UIP than do those in countries adopting more flexible exchange rate regimes. After a crisis, several crisis countries have switched to more flexible exchange rate regimes. If the changes in exchange rate regimes cause foreign investors to significantly adjust their expectations about the exchange rates, the absolute value of parameter $\mathrm{P}_{\varepsilon}$, which measures the expected exchange rate deviation from the conventional UIP, should be higher before a crisis than after a crisis. The specific predictions for $\mathrm{H}_{0}$ and $\mathrm{H}_{\mathrm{A}}$ are

$$
\begin{aligned}
& \mathrm{H}_{\mathrm{O}}^{4}:\left|\mathrm{P}_{\varepsilon}^{\text {before }}\right|=\left|\mathrm{P}_{\varepsilon}^{\text {after }}\right| \\
& \mathrm{H}_{\mathrm{A}}^{4}:\left|\mathrm{P}_{\varepsilon}^{\text {before }}\right|>\left|\mathrm{P}_{\varepsilon}^{\text {after }}\right| .
\end{aligned}
$$

\subsection{Thailand}

Thailand is a small open country, which experienced a boom in the late 1980s through the mid 1990s and then a bust in the late 1990s along with much of Southeast Asia. Thailand's economy grew at an average annual rate of 9\% during 1987-1996 (Alba, Hernandez \& Klingebiel, 1999). The real GDP growth rate dropped to $-1.4 \%$ in 1997 and $-10.6 \%$ in 1998 . Subsequently, the economy has had uninterrupted growth at an average rate of $4.5 \%$ per annum since 1999 . The seasonally-adjusted 
(SA) GDP at 1988 prices and the SA GDP at current market prices for 2007 are estimated to be 4.3 trillion baht (around 122 billion USD) and 8.5 trillion baht (around 243 billion USD), respectively. ${ }^{13}$ Market capitalization of publicly traded equities at the end of 2007 was 6.6 trillion baht (around 190 billion USD) or about $78 \%$ of GDP. ${ }^{14}$

Thailand is also largely a bank-based economy. The ratio of bank lending to total external finance during 1993-2007 was between 35\% and 78\% with an average at 52\% (Akrasanee, 2008). Based on a survey by the Bank of Thailand in 2002, loans from financial institutions accounted for more than $90 \%$ of firms' external funds. Hence, the banking sector has been playing a major role in channeling funds to the corporate sector in Thailand.

As documented by Alba et al. (1999), in the late 1980s through early 1990s, the Thai government embarked on a program to further liberalize the current and capital account as well as the financial sector, but continued to keep its exchange rate pegged to a basket of currencies. For instance, the authorities improved tax treatment and reduced tax impediments to portfolio inflows during 1986-1992, the ceilings on bank deposit and lending rates were removed during 1989-1992, and current account transactions were free of foreign exchange restrictions by the end of 1994 . The most important change was the establishment of the Bangkok International Banking Facility (BIBF) in 1993 as a means to promote Thailand as a regional financial center. BIBFs benefited from several tax and regulatory advantages. For example, the corporate income tax for BIBFs was $10 \%$ rather than $30 \%$, and short-term BIBF monetary instruments, unlike other deposit-type instruments, were not subject to the $7 \%$ cash reserve requirements. In addition, there have been investment promotion privileges from the Board of Investment (BOI) both in terms of tax and non-tax incentives (e.g., exemption of import duty and value added tax (VAT) on machinery and raw materials,

\footnotetext{
${ }^{13}$ GDP data are obtained from the Office of National Economic and Social Development Board (NESDB).

${ }^{14}$ Stock market capitalization data are obtained from the Thai Bond Market Association (ThaiBMA).
} 
corporate income tax exemption, and permission to bring in foreign workers, own land and take or remit foreign currency abroad).

Financial liberalization together with the pace of economic growth, stable exchange rates, and attractive interest rate differentials resulted in a surge in private capital inflows to Thailand in the late 1980s and the early 1990s. As documented by Alba et al. (1999), during 1988-1996, Thailand received the cumulative amount of capital inflows of 100.3 billion USD (55\% of 1996 GDP or 9.4\% of GDP on average per annum). As most of the inflows were in the form of loans, the ratio of foreign debt to total debt of Thailand increased from $59.1 \%$ in 1988 to $94.1 \%$ at the end of 1997 (Alba et al., 1999). Moreover, there was a rapid build-up of private short-term debt. The Bank of Thailand estimated that short-term external debt increased from 10 billion USD (12\% of GDP) in 1990 to 41 billion USD (24\% of GDP) in 1995 (Alba et al., 1999). During this period, financial institutions played a key and increasing role in transmitting capital inflows. The share of bank foreign borrowing in the total inflows rose from 10\% during 1988-1992 to 60\% during 1993-1996, and the increase in short-term debt of 30 billion USD during 1990-95 was attributed almost entirely to banks (Alba et al., 1999). In contrast, the net inflows of foreign direct investment (FDI) were relatively stable since FDI investors aimed for longer-run returns and were attracted by special privileges from the government's Board of Investment and long-term macroeconomic outlook (Siamwalla, Vajragupta \& Vichyanond, 1999).

The influx of capital flows to Thailand was accompanied with a lending boom, excessive spending or investment, and a declining quality of bank assets. Credit outstanding grew on average at a rate of 22\% per annum in real terms during 1988-1995 (Alba et al., 1999). The loan to deposit ratio of commercial banks rose from $96 \%$ in 1988 to $112 \%$ in 1995 , suggesting that banks substituted riskier loan assets for lower risk assets (e.g., cash and government bonds) (Alba et al., 1999). The situation was aggravated by an increasing tendency for bank loans to be granted based on collateral value more than cash flow. Moreover, banking supervision was not quite up to international 
standards at that time. For example, bank loans were not considered impaired until being delinquent for 6 months, as opposed to 3 months which is the standard international practice. The on-site supervision also focused on transaction testing rather than major risk assessment.

The deteriorating economic conditions started to manifest on both macro and micro sides in 1996, and the crisis hit the country in 1997. On the macro side, Thailand's current account deficit rose to 8\% of GDP during 1995-1996 (Siamwalla et al., 1999). On the micro side, there was a sign of ailing financial institutions (Siamwalla et al., 1999). Bangkok Bank of Commerce was seized by the Bank of Thailand in May 1996, followed by 10 finance companies being ordered to raise capital in March 1997 and the operations of 16 insolvent finance companies being suspended in June 1997. In early 1997, there was a wide anticipation of baht devaluation, leading to large capital outflows (mostly from the financial sector) (Siamwalla et al., 1999). Such huge capital outflows caused a rapid depletion of the country's international reserves. The Thai government inevitably had to float the baht on July 2, 1997. This incidence was followed by the suspension of additional 42 finance companies' operations on August 5, 1997.

Thailand requested IMF assistance and attempted to regain public confidence as well as to improve the quality of institutions and domestic policies in medium and long terms through several reform measures. Immediate measures include the closure of 56 finance companies, the blanket guarantee for financial institutions' depositors and creditors to stop the run, and the financial restructuring package to facilitate recapitalization in the banking sector. Examples of medium-term measures include the establishment of a credit bureau and upgrading supervisory policies to international standards. Starting from the accounting period ending on December 31, 1998, financial institutions are required to classify and set provisions for their assets according to the borrowers' financial condition and debt repayment ability as well as the length of non-payments. Under the new rules, a loan which is 3 months overdue must be classified as substandard and subject to $20 \%$ loan loss provision at the minimum. Since 1999, the supervision and examination of financial institutions 
by the Bank of Thailand have focused on risk management of financial institutions, rather than transaction testing. Furthermore, there are a number of longer-term measures, such as the New Financial Institutions Act to provide a more effective framework for safeguarding the country's financial stability, the improvement of accounting standards and guidelines, and the establishment of a deposit insurance agency to replace the blanket guarantee with a limited guarantee. ${ }^{15}$ In addition, the Board of Investment revised Thailand investment policies to relieve the fiscal burden of the government after the crisis. Several tax privileges have been reduced, and the efficiency and effectiveness of tax privileges have been enhanced. For instance, tax privileges are granted to projects that benefit the economy, and good governance is used for managing and supervising the application of tax and duty privileges. In addition, the priority of those privileges is given to the regions with low income and inadequate investment, small and medium enterprises, and five main sectors (i.e., agriculture and agricultural products, projects related to technological and human resource development, public utilities and infrastructure, environmental protection and conservation, and targeted industries). Those reform measures may help reduce the moral hazard problems at the bank, international, and corporate levels and enhance the benefits of international capital flows to Thailand.

Based on the above facts, Thailand exhibits characteristics consistent with the key assumptions of the model. It is therefore a good example of a bank-based, small open economy, to which the model can be applied to study the relationships between international capital flows and each sector of the economy, as well as to assess the impact of changes in the quality of institutions and domestic policies on the costs and benefits of international capital flows.

\footnotetext{
${ }^{15}$ This discussion draws from information provided in the Bank of Thailand's Supervision Report 2000.
} 


\section{CHAPTER VI}

\section{DATA}

The parameter values characterizing the model are calibrated and estimated using the equilibrium conditions in Appendix A to fit Thailand data. The data used are of monthly frequency from January 1993 to June 2007, covering the pre-crisis, crisis and post-crisis periods. When actual monthly data are not available (which is the case for output, investment, and consumption), relevant monthly indices (manufacturing production index, private investment index, and private consumption index) are used to approximate actual monthly data. In addition, when the data are not available for the whole sample period, the series are extended using predicted values based on appropriate explanatory variables. Table 1 describes how each variable is obtained or computed.

Monthly data on real sector indices are obtained from the Bank of Thailand (BOT) while real sector data with lower frequencies are derived from the Office of National Economic and Social Development Board (NESDB). These data are in real terms at 1988 prices and are seasonallyadjusted (SA). In the model, there is only traded output. To make sure that the output and the private investment data represent as closely as possible the traded output and the private investment in traded sectors, respectively, the output from the banking and real estate sectors is excluded from the total output, and the net private capital stock of the banking and real estate sectors is subtracted from the total net private capital stock. The employed labor, international reserves, and bank data are obtained from the BOT. Since the employed labor data are of mixed frequencies (semiannual from 1993 to 1997, quarterly from 1998 to 2000 , and monthly from 2001 on), linear interpolation is used to derive a series of monthly employed labor for the whole sample period. In addition, the monetary aggregate and interest rate data are derived from the International Financial Statistics (IFS) of the International 
Monetary Fund (IMF). The exchange rate, inflation rate, and price level data are obtained from Datastream.

Table 2 reports the summary statistics of the level variables in panel A and the change variables in panel B for the whole sample period. The average annual traded output (total GDP minus GDP from financial intermediations and real estate, renting and business activities) in real terms (real output) is 2.93 trillion baht (around 83 billion USD) while the average annual private investment in traded sectors (total private investment excluding investment in the banking, insurance, and real estate sectors) in real terms (real investment) is 592 billion baht (around 17 billion USD). Banks' foreign borrowing is on average 8.9 billion USD. As expected, time variations in most level variables are small. The exceptions are the banks' net foreign borrowing and the domestic real deposit rate, which have relatively high standard deviations compared to their means. In addition, the banks' net foreign borrowing is highly right-skewed; thus, its mean ( 8.9 billion USD) is much higher than its median (1.9 billion USD). According to the augmented Dickey-Fuller (ADF) unit roots tests, all change variables are stationary whereas all level variables are not. Therefore, the parameter estimation in the following chapters will be based on change variables, and the equilibrium conditions in Appendix A will be rearranged in the form of first difference equations.

Hypothesizing that the variables behave differently before and after the crisis due to the crisis and the reforms, the sample is divided into 3 sub-periods, using June 1997 (the month in which the operations of 16 insolvent finance companies were suspended) and December 2000 (the end of the financial restructuring plan) as the breakpoints. The three sub-periods are (1) pre-crisis period from January 1993 to May 1997, (2) crisis (and reform) period from June 1997 to December 2000, and (3) post-crisis period from January 2001 to June 2007.

Table 3 reports the summary statistics of the level variables in panel A and the change variables in panel B for the pre-crisis, crisis, and post-crisis periods. Figure 1 plots time-series 
patterns of the level variables over time. As seen in Table 3 and Figure 1, the domestic macroeconomic and financial variables reflect the economic conditions of Thailand reasonably well. All of them move in an adverse direction during the crisis. The levels of real output, real consumption, and the real monetary aggregate exhibit an increasing trend from the pre-crisis to postcrisis periods. Such a positive trend is nevertheless disrupted during the crisis. The average changes in those variables are the lowest in the crisis period. Moreover, the data reveal the investment boom and an influx of capital flows to the banking sector in the pre-crisis period. The average real investment and banks' net foreign borrowing are the highest in the pre-crisis period at 846 billion baht (around 24 billion USD) and 28.8 billion USD, respectively. The boom is however followed by a big drop in real investment during the crisis and a declining trend for banks' net foreign borrowing since the crisis. Average real investment is much lower at 377 billion baht (around 11 billion USD) during the crisis and average banks' net foreign borrowing goes down to 16.1 billion USD during the crisis and then to -8.6 billion USD after the crisis. Other variables also reflect weak economic conditions during the crisis. Banks' non-performing loans to total loans ratio (NPL ratio), domestic interest rates, and inflation rate rise dramatically. In addition, the data show that international reserves were depleted extremely quickly after the central bank's attempt to defend the baht in early 1997, and the real value of the local currency against foreign currency depreciated substantially after the government decided to switch from a pegged exchange rate to a managed float regime in July 1997.

The above univariate analysis suggests that there have been two structural changes in Thailand during the sample period, i.e., the boom before the crisis, the bust during the crisis, and the improvement after the crisis. Hence, the parameters of interest should be estimated for each of these sub-periods. Also those time-series data are not stationary in levels; thus, the equations to be fitted need to be rearranged in first difference form to ensure stationarity. In addition, there have been co-movements among those variables before, during, and after the crisis, and the interest rates are 
more volatile than the variables depending on them. A preliminary analysis of the co-movements among variables is thus conducted by looking at the correlations between the left-hand side (LHS) and the right-hand side (RHS) variables in the structural equations in Appendix A. Table 4 restates the equilibrium conditions and reports the correlations between the LHS and the RHS variables. Most of the correlations (in bold font) are of expected sign and of significant magnitude while only some are not. One reason for not getting the expected sign and significant magnitude could be that those RHS variables, except $\mathrm{i}^{\mathrm{w}}$, are endogenous and are related to the LHS variables not only via a single equation in the system, but also through their relationships with other variables in other equations as well. Another possible explanation is that there were some structural changes (e.g., the crisis and the reforms), which may alter the sign or reduce the magnitude of the correlations between the variables. Despite these possible explanations, it is still puzzling why the correlation between the real investment $\left(\mathrm{I}_{\mathrm{t}}\right)$ and the change in the real deposit rate $\left(\mathrm{r}_{\mathrm{t}}-\mathrm{r}_{\mathrm{t}-1}\right)$ and the correlation between the growth rate of real consumption $\left(\mathrm{C}_{\mathrm{t}} / \mathrm{C}_{\mathrm{t}-1}\right)$ and the lagged real deposit rate $\left(\mathrm{r}_{\mathrm{t}-1}\right)$ are not of the expected sign. This issue will be further examined in the next chapter. 


\section{CHAPTER VII}

\section{METHODOLOGY}

This chapter describes the methodology used to calibrate and estimate parameters and to test the hypotheses with regard to structural changes in the quality of institutions and domestic policies. The model derived in Chapter IV is slightly modified to simplify the estimation and to ensure stationarity. The parameters measuring the severity of moral hazard problems, which are proxies for the quality of institutions and domestic policies, are then estimated for each sub-period using the partial-sample generalized method of moments (GMM) approach. All other parameters are either obtained from related studies or calibrated using long-run data relations. The hypotheses, as outlined in section 5.2, are tested using the Wald-type structural break tests with known breakpoints by Andrews and Fair (1988) under the GMM framework.

\subsection{Model Modifications}

\subsubsection{Moving Average of Interest Rates}

According to the equilibrium conditions (A2), (A8) and (A9) in Appendix A, the real net capital stock (whose change determines the level of real investment), the growth rate of real consumption, and the real monetary aggregate are supposed to move closely with the domestic interest rate. However, the univariate analysis in Chapter VI suggests that those variables are much less volatile than the domestic interest rate. In addition, the correlation between the real investment and the change in the real deposit rate and the correlation between the growth rate of real consumption and the lagged real deposit rate are not strong and not of the expected sign. A possible explanation could be that in reality firms and households smooth their investment, consumption, and money holding decisions over the business cycle, weakening the contemporaneous relationships 
between those variables and the relevant interest rates. This seems to suggest that it is more appropriate to use moving averages of interest rates over the business cycle, rather than one-period interest rates, in the equilibrium conditions (A2), (A8) and (A9). In computing the moving averages of interest rates, the business cycle is assumed to be 11 years, as it is suggested by Clement Juglar that the fixed investment cycle is between 7 and 11 years. Table 5 compares the correlations between the selected macroeconomic variables (i.e., real net capital stock, real investment, growth rate of real consumption, and real monetary aggregate) and the relevant interest rates when using one-period interest rates versus eleven-year moving averages of interest rates. The results show that the correlations when using the eleven-year moving averages of interest rates are of the expected sign, and the magnitudes are much higher. These results suggest that using the eleven-year moving averages of interest rates in the equilibrium conditions (A2), (A8) and (A9) significantly increases the fit of the model to the actual data.

\subsubsection{Adjustment in Investment Equation}

There are real-world frictions or factors that are not considered by the model. Figure 1C shows that real investment is very persistent. Empirically, the persistence of investment (e.g., due to large-scale long-term projects) suggests a need to include lagged investment as an additional explanatory variable for current investment and modify the equilibrium condition (A3) as follows.

$$
\mathrm{I}_{\mathrm{t}}=\operatorname{Inv}_{0} \cdot\left[\mathrm{K}_{\mathrm{t}}^{\mathrm{M}}-(1-\mathrm{d}) \mathrm{K}_{\mathrm{t}-1}^{\mathrm{M}}\right]+\operatorname{Inv}_{1} \cdot\left[\mathrm{I}_{\mathrm{t}-1}\right]
$$

where $\mathrm{K}_{\mathrm{t}}^{\mathrm{M}}=$ Level of capital stock calculated from the model

$$
\begin{cases}\mathrm{K}_{\mathrm{t}}^{\mathrm{MD}}=\overline{\mathrm{L}}\left(\frac{\alpha(\mathrm{A}+\mathrm{n})}{\mathrm{r}_{\mathrm{t}}+\xi+\mathrm{d}}\right)^{\frac{1}{1-\alpha}} & \text { if }\left(\frac{\varepsilon_{\mathrm{t}}}{\mathrm{P}_{\mathrm{t}}}\right) \mathrm{R}_{\mathrm{t}-1} \geq \beta \mathrm{F}_{t} \\ \mathrm{~K}_{\mathrm{t}}^{\mathrm{MD}}-(1-\varphi)\left(\mathrm{F}_{\mathrm{t}}^{\mathrm{D}}-\left(\frac{\varepsilon_{\mathrm{t}}}{\mathrm{P}_{\mathrm{t}}}\right)\left(\frac{\left.\mathrm{R}_{\mathrm{t}-1}\right)}{\beta}\right)\right) & \text { if }\left(\frac{\varepsilon_{\mathrm{t}}}{\mathrm{P}_{\mathrm{t}}}\right) \mathrm{R}_{\mathrm{t}-1}<\beta \mathrm{F}_{t}\end{cases}
$$

Parameters $\operatorname{Inv}_{0}$ and $\mathrm{Inv}_{1}$ indicate how much current investment is determined by the model and how much by previous period's investment, respectively. 
This modification will however affect the magnitude of the impact of a sudden stop on bank lending to the corporate sector and on firms' investment predicted by the model. Particularly, when banks face a credit cut by foreign creditors of the amount $\left(\mathrm{F}_{t}^{\mathrm{D}}-\left(\varepsilon_{\mathrm{t}} / \mathrm{P}_{\mathrm{t}}\right)\left(\mathrm{R}_{\mathrm{t}-1} / \beta\right)\right)$, bank lending and firms' investment will decline by $\operatorname{inv}_{0}(1-\varphi)\left(\mathrm{F}_{\mathrm{t}}^{\mathrm{D}}-\left(\varepsilon_{\mathrm{t}} / \mathrm{P}_{\mathrm{t}}\right)\left(\mathrm{R}_{\mathrm{t}-1} / \beta\right)\right)$, rather than by $(1-\varphi)\left(\mathrm{F}_{\mathrm{t}}^{\mathrm{D}}-\left(\varepsilon_{\mathrm{t}} / \mathrm{P}_{\mathrm{t}}\right)\left(\mathrm{R}_{\mathrm{t}-1} / \beta\right)\right)$. Similarly, transfers that banks receive from the government to finance their cash shortfalls during a sudden stop will be $\left\{1-\operatorname{inv}_{0}(1-\varphi)\right\}\left(\mathrm{F}_{\mathrm{t}}^{\mathrm{D}}-\left(\varepsilon_{\mathrm{t}} / \mathrm{P}_{\mathrm{t}}\right)\left(\mathrm{R}_{\mathrm{t}-1} / \beta\right)\right)$, rather than $\varphi\left(F_{t}^{D}-\left(\varepsilon_{t} / P_{t}\right)\left(R_{t-1} / \beta\right)\right)$

\subsubsection{Exogenous Public Sector Policies}

Due to the limitation of the data regarding the details of the government finance account, assumptions have to be made to ensure that the budget constraint of the public sector holds. Because the focus of this research is not primarily on the public sector, it is assumed for the empirical analysis that public sector policies and related variables, i.e., international reserves (R) and inflation rate $(\pi)$, are exogenous. In addition, it is assumed that the bailout period, in which there will be a series of transfers of the remaining banks' non-performing loan (NPL) losses to the government to clean up the banking system, starts one year after the first sudden stop.

\subsubsection{First Difference Equations to Ensure Stationarity}

The augmented Dickey-Fuller (ADF) tests for unit roots suggest that all the observed endogenous variables are not stationary. Consequently, the estimation is based on change variables, and the equilibrium conditions (after the modifications in this section) are rearranged in the form of first difference equations. Appendix E presents the equilibrium conditions for the observed endogenous variables in first difference form, after the modifications according to sections 7.1.1-7.1.3. 


\subsection{Calibration and Estimation}

The parameters of interest $\left(v, n, \Psi_{1}, P_{\varepsilon}\right)$, along with the related parameters which are anticipated to change after the crisis $\left(\Psi_{0}, \operatorname{Inv}_{0}, \operatorname{Inv}_{1}\right)$, are estimated for the pre-crisis, crisis, and postcrisis periods using the partial-sample GMM approach while all other parameter values are specified exogenously (i.e., obtained from related studies or calibrated using long-run data relations). Table 6 lists exogenously-determined parameters and describes how each of these parameters is obtained.

Given the exogenously-determined parameter values and the assumption that $\mathrm{X}_{0}=\mathrm{F}_{0}=\mathrm{FX}_{0}=$ $\operatorname{AFX}_{0}=0$, the parameter values $\left(v, n, \Psi_{0}, \Psi_{1}, P_{\varepsilon}, \operatorname{Inv}_{0}, I n v_{1}\right)$ for each sub-period are estimated to fit the following first difference equations.

$$
\begin{aligned}
& b_{t}-b_{t-1}=f n\left(v, n, \operatorname{Inv}_{0}\right), \\
& I_{t}-I_{t-1}=f n\left(n, \operatorname{Inv}_{0}, \operatorname{Inv}_{1}, v\right), \\
& r_{t}-r_{t-1}=f n\left(\psi_{0}, \Psi_{1}\right), \\
& \frac{\varepsilon_{t}}{P_{t}}-\frac{\varepsilon_{t-1}}{P_{t-1}}=f n\left(P_{\varepsilon}\right) .
\end{aligned}
$$

Note that only equations (E2), (E4), (E5), and (E8) in Appendix E are relevant. All other equations are determined by exogenously-determined parameters; therefore, there are no parameter values to be estimated from those equations.

To address the endogeneity problem and to increase the number of moment conditions for better identification, several global financial market and economic indicators as well as their own lagged variables are utilized as instruments. These include the change in the world interest rate, the change in the world inflation rate, the percentage change in the world industrial production index, and the $\log$ return on the spot JPY/USD exchange rate. Appendix F provides the descriptions and the sources of variables used as instruments. These variables are considered good instruments, since they are not likely to be impacted by changes in economic and financial market conditions of a small open economy and hence are not determined by any of the endogenous variables in the model. Furthermore, theoretically and conceptually they can help explain variations in endogenous variables 
of the model. For example, changes in the world financial market conditions (as reflected by the change in the world interest rate, the change in the world inflation rate, and the log return on the spot JPY/USD exchange rate) will surely have an impact on changes in the exchange rate, the interest rate, and the capital flows of a small open economy. In addition, a slowdown of the world economy (as reflected by a decline in the world industrial production index) may also attract world capital flows into a small open economy, leading to an increase in domestic industrial production.

\subsection{GMM and Hypothesis Testing Methodology}

The hypotheses of structural changes in the quality of the institutions and domestic policies, as measured by changes in the parameters measuring the severity of moral hazard problems, can be tested using F-statistics with two known breakpoints (since there are three sub-periods: pre-crisis, crisis, and post-crisis periods). In fact, there are several versions of F-tests for a structural break with a known breakpoint. ${ }^{16}$ As mentioned by Andrews and Fair (1988), the F-test discussed by Chow (1960) is typically used for linear regression models while the extensions of Chow's F-test by Lo and Newey (1985) or Hodoshima (1986) can be used for linear simultaneous equations models. Since the model developed in this dissertation is in the form of non-linear simultaneous equations, the F-test for non-linear simultaneous equations models by Andrews and Fair (1988), with the applications for GMM discussed by Andrews (1993), is more appropriate. Three types of F-tests are proposed by Andrews and Fair (1988): Wald-type (using parameter estimates based on the alternative hypothesis), LM-type (using parameter estimates based on the null hypothesis), and LR-type (using parameter estimates based on both the alternative and the null hypotheses). Since parameter values are estimated under the alternative hypothesis that they are different across sub-periods, it seems most appropriate to use Wald-type statistics for hypothesis testing. However, the F-test by Andrews and

\footnotetext{
${ }^{16}$ Based on the literature review by Stock and Watson (1996), Hansen (2000, 2001), and Cai (2007), other types of structural break tests include (1) F-tests with an unknown breakpoint, e.g., Quandt (1960), Andrews (1993), Andrews and Ploberger (1994), (2) OLS-based CUSUM and MOSUM tests, e.g., Brown, Durbin, and Evans (1975), Ploberger and Kramer (1992), and (3) Tests based on maximum likelihood scores against the alternative hypothesis that the coefficients follow a random walk (stochastic trends),e.g., Nyblom (1985), and (4) Tests for linear models with more than one breakpoints, e.g., Bai and various co-authors.
} 
Fair (1988) was originally developed for one known breakpoint. This test therefore needs to be slightly modified to accommodate two known breakpoints. The steps to calculate GMM estimators for each sub-period (partial sample GMM estimators) and Wald statistics with two known breakpoints following the idea of Andrews and Fair (1988) and Andrews (1993) are outlined in Appendix G. 


\section{CHAPTER VIII}

\section{EMPIRICAL RESULTS}

This chapter analyzes the results from the partial-sample GMM estimation using Thailand data for the parameters measuring the severity of moral hazard problems $\left(v, n, \Psi_{1}, \mathrm{P}_{\varepsilon}\right)$ as described in section 5.1 in Chapter $\mathrm{V}$ and the related parameters $\left(\Psi_{0}, \operatorname{Inv}_{0}, \operatorname{Inv}_{1}\right)$ for the pre-crisis, crisis, and post-crisis periods. The Wald statistics for the structural break tests are also examined to see if the changes in the quality of institutions and domestic policies as part of the reform plan lead to significant reductions in moral hazard problems after the crisis.

\subsection{Main Results}

Partial-sample GMM estimators of parameters $\left(v, n, \Psi_{0}, \Psi_{1}, P_{\varepsilon}, \operatorname{Inv}_{0}, \operatorname{Inv}_{1}\right)$, along with their approximate standard errors, t-statistics, and p-values, are reported in Table 7. Almost all of the parameter estimates are significantly different from zero. The exceptions are the estimated values of the interest rate sensitivity to the world interest rate $\left(\psi_{0}\right)$ for the crisis and post-crisis periods, the interest rate sensitivity to the aggregate level of banks' net foreign borrowing $\left(\psi_{1}\right)$ for the pre-crisis period, the expected exchange rate deviation from the conventional uncovered interest rate parity (UIP) $\left(\mathrm{P}_{\varepsilon}\right)$ for the post-crisis period, and the loan loss provisioning ratio $(\mathrm{v})$ for the crisis period. The estimate of $v$ for the crisis period is set to zero, the lower bound of allowed parameter values. The estimate of $v$ for the post-crisis period is set to the upper bound value of one. In addition, the J-statistic for the test of over-identifying restrictions suggests that the null hypothesis that the moment conditions included in the GMM estimation are zero cannot be rejected. 
In general, the values of the parameters of interest are significantly different across sub-periods. Table 8 reports the Wald statistics and the p-values for the structural break tests. ${ }^{17}$ Recall that $v$, the loan loss provisioning ratio, can be interpreted as a measure of the moral hazard problem at the bank level. The estimated values are 52\%, $0 \%$, and $100 \%$ for the pre-crisis, crisis, and post-crisis periods, respectively. The value of $52 \%$ indicates that banks did not maintain sufficient provisions to cover their non-performing loan (NPL) losses before the crisis, and the underprovisioning problem became more severe during the crisis. However, after the crisis, the estimation indicates that banks have maintained 100\% loan loss provisions for their NPL losses. Such a change can be largely explained by the stricter loan loss provisioning rules and improved banking supervision standard, which were part of the financial system reforms in Thailand. The estimated values of parameter $n$, which indicates the level of government subsidies (or taxes if negative) to the corporate sector as well as the degree of the moral hazard problem at the corporate level, exhibit a downward trend, from -3.8 before the crisis, to -13.0 during the crisis, and -29.0 after the crisis, and such differences are statistically significant. This trend is consistent with the fact that the Board of Investment of Thailand changed the investment promotion policies by giving lower tax incentives to firms and imposing more stringent criteria for firms eligible for tax privileges after the crisis.

Recall that one of the moral hazard problems at the international level is captured by parameter $\psi_{1}$ (a measure of the interest rate sensitivity to the aggregate level of banks' net foreign borrowing in 10 trillion USD unit). The estimated value is not different from zero before the crisis whereas it is estimated to be 0.84 during the crisis and 1.46 after the crisis. On the other hand, parameter $\psi_{0}$ (a measure of the interest rate sensitivity to the world interest rate) is estimated to be 1.18 before the crisis while it is not significantly different from zero during and after the crisis. The differences in the estimated values of $\psi_{0}$ and $\psi_{1}$ for the pre- and post-crisis periods are significant at $1 \%$ and $10 \%$ confidence level, respectively. These results suggest that the foreign borrowing rate,

\footnotetext{
${ }^{17}$ The structural break tests for parameter $v$ cannot be conducted since the values of $v$ for the crisis and postcrisis periods are at the boundaries of the parameter value range.
} 
which previously moved with the world interest rate before the crisis, is largely determined by the aggregate level of banks' net foreign borrowing since the crisis. This shift likely reflects a change in foreign creditors' perceptions of risks associated with their lending to the banking sector in Thailand after witnessing the crisis and acknowledging the plan by the government to replace the blanket guarantee with a limited guarantee. Particularly, an increase in the aggregate level of banks' net foreign borrowing of 10 billion USD is expected to be accompanied by a rise in the foreign borrowing rate of $1.0 \%$ per annum during the crisis and $1.8 \%$ per annum after the crisis to compensate for foreign creditors' higher risks from the greater amount of their lending to the banking sector in Thailand.

The estimated values of parameter $\mathrm{P}_{\varepsilon}$ also reflect the changes in the expected exchange rate deviation from the conventional UIP by market participants. $\mathrm{P}_{\varepsilon}$ before the crisis $(0.0044)$ is positive and larger in magnitude than $\mathrm{P}_{\varepsilon}$ after the crisis (which is not significantly different from zero). This suggests that the expected exchange rate deviation from the UIP is much smaller after 2000. This is intuitive, since Thailand switched from a pegged exchange rate to a managed float regime with significantly less market intervention by the government. However, $\mathrm{P}_{\varepsilon}$ during the crisis is highly negative at -0.0095 , indicating that market participants expected the exchange rate to depreciate more than the level suggested by the UIP relationship. This potentially worsened the situation during the crisis. Parameters $\operatorname{Inv}_{0}$ and $\operatorname{Inv}_{1}$, which measure how much actual investment is determined by contemporary investment suggested by the model and how much by lagged investment, are in general not significantly different across sub-periods. Only the difference between $\operatorname{Inv}_{0}$ for the crisis and post-crisis periods is significant at $10 \%$ confidence level. These results suggest that the relationship between lagged and current investment is stable as would be the case if a simple mechanical relationship (such as that dictated by large long-lived projects) is mostly responsible for determining this parameter. 
In sum, the empirical results show that the values of all the parameters measuring the severity of moral hazard problems are significantly different across sub-periods, especially between the preand post-crisis periods. These significant changes in the parameter values suggest that the changes in the quality of institutions and domestic policies in Thailand after the crisis bring about substantial reductions in the moral hazard problems at all levels. At the bank level, the improved banking supervision and the more stringent loan loss provisioning rules lead to the higher banks' loan loss provisioning ratio after the crisis. At the corporate level, the changes in the investment promotion policies by the Board of Investment result in the lower level of government subsidies or tax incentives to firms. At the international level, the occurrence of the crisis and the plan to replace the blanket guarantee with a limited guarantee (through the establishment of a deposit insurance agency) cause foreign creditors to change their estimations of risks stemming from their lending to the banking sector in Thailand. In addition, the change from a fixed exchange rate to a managed float regime causes foreign investors to adjust their expectations about the exchange rate. The improvement in the foreign investors' risk estimations and expectations about the exchange rate leads to the higher interest rate sensitivity to the aggregate level of banks' net foreign borrowing and the lower expected exchange rate deviation from the UIP relationship. In the next chapter, the impact of those changes in the quality of institutions and domestic policies on the net benefit of international capital flows will be assessed using the simulation exercises.

\subsection{Sensitivity and Stability Analysis}

The estimation results in section 8.1 depend on several exogenously-determined parameters and the assumption that those parameters are constant over time. In this section, the sensitivity analysis is conducted to examine the effects of changes in those exogenously-determined parameters as well as a change in the parameter measuring the households' degree of risk aversion over time on the estimation results. Other issues with regard to the partial-sample GMM estimation, i.e., convergence to a local minimum rather than the global one, choices of kernels and bandwidth 
parameters for the estimation of the optimal weighting matrix, and different alternatives for breakpoints, are also investigated in this section.

\subsubsection{Change in Households' Degree of Risk Aversion over Time}

The estimation results in section 8.1 show that there have been a significant increase in the interest rate sensitivity to the aggregate level of banks' net foreign borrowing $\left(\psi_{1}\right)$ and a reduction in the interest rate sensitivity to the world interest rate $\left(\psi_{0}\right)$ after the crisis. These changes suggest that foreign investors demand much higher rates of return to compensate for their higher risks from an increase in their lending to the banking sector in Thailand. In equilibrium, the deposit rate is set to be equal to the foreign borrowing rate. Hence, the changes in parameters $\psi_{0}$ and $\psi_{1}$ after the crisis also affect the deposit rate and may also be influenced by a change in households' saving behavior or degree of risk aversion.

In this model, households choose the levels of consumption, money holdings, and deposits with banks to maximize their expected utility. Although earning zero interest, money holdings are considered safer and more liquid than deposits with banks since the principal amount can be immediately accessed with certainty. Hence, households' demand for money holdings relative to depositing their money in banks reflects their degree of (liquidity) risk aversion. In equilibrium, households' money balances increase with parameter $\chi$, and a higher level of money holdings leads to a lower level of deposits with banks. Therefore, $\chi$ can be used to measure the households' degree of risk aversion. Particularly, the higher the value of $\chi$, the greater the households' preference for money holdings relative to deposits with banks, and the higher the households' degree of risk aversion. The higher households' degree of risk aversion causes the amount of deposits with banks to go down since households prefer to hold money with them. This may drive banks to increase the deposit rate to attract more deposits from households and may affect the estimated values of $\psi_{0}$ and $\psi_{1}$ derived in section 8.1 . 
To examine the effect of a change in households' degree of risk aversion on the changes in the values of $\psi_{0}$ and $\psi_{1}$ after the crisis, the value of $\chi$ is estimated and allowed to be different across sub-periods, rather than applying the same exogenously-determined value for all sub-periods. When the parameters measuring the severity of moral hazard problems and $\chi$ are simultaneously estimated, the results indicate that households' degree of risk aversion $(\chi)$ declines from 0.01 before the crisis to 0.0053 during the crisis and 0.0042 after the crisis. Although the value of $\chi$ is decreasing, $\psi_{1}$ still exhibits an increasing trend, and the value of $\psi_{0}$ still significantly decreases during and after the crisis. These results suggest that the change in households' degree of risk aversion over time does not have a significant influence on the increase in the interest rate sensitivity to the aggregate level of banks' net foreign borrowing $\left(\psi_{1}\right)$ and the reduction in the interest rate sensitivity to the world interest rate $\left(\psi_{0}\right)$ after the crisis. All other main results still hold under this specification.

\subsubsection{Changes in Exogenously-Determined Parameters}

The estimation results in section 8.1 are based on a number of exogenously-determined parameters appeared in equations (E2), (E4), (E5), and (E8) in Appendix E, which are either calibrated using long-run data relations or obtained from other studies. The sensitivity analysis is therefore conducted to examine the impact of a change in each of those parameters on the estimation results.

1) An increase in the production technology factor (A) results in higher output and thus causes firms to increase their investment according to the model. Recall that current investment is a function of contemporary investment predicted by the model (the model prediction part), which increases with parameter $\mathrm{A}$, and lagged investment (the lagged part). Parameters $\operatorname{inv}_{0}$ and $\operatorname{inv}_{1}$ indicate how much current investment is determined by the model prediction part and how much by the lagged part, respectively. A rise in parameter A leads to an increase in contemporary investment predicted by the model. To counter such an effect, the estimated value of the weight given to the model prediction part $\left(\mathrm{inv}_{0}\right)$ is lower during the pre-crisis and post-crisis periods (when lagged 
investment is high and when investment shows an increasing trend) to reduce the effect of the increase in the model prediction part. In contrast, the estimated value of inv $v_{0}$ is higher during the crisis period (when lagged investment is low and when a trend reverses from decreasing to increasing) to enhance the effect of the increase in the model prediction part.

The increase in the model prediction part of investment as a result of the increase in A also causes the level of banks' net foreign borrowing to increase. To bring the banks' net foreign borrowing back to the same level, the estimated value of the parameter measuring the level of government subsidies or tax incentives (n) increases, resulting in higher household income (dividends) from the corporate sector, higher household deposits with banks and lower banks' demand for foreign borrowing. In addition, the estimated value of the banks' loan loss provisioning ratio (v) is higher, leading to lower banks' NPL losses and lower banks' demand for foreign borrowing.

2) An increase in the income share of capital $(\alpha)$ affects the estimation results in the same way as an increase in the production technology factor (A). However, the impact of a change in parameter $\alpha$ is expected to be larger than that of a change in parameter $\mathrm{A}$ due to its non-linear, exponential relationship with output.

3) An increase in the capital depreciation rate (d) leads to an increase in firms' expenses, causing firms to reduce their new investment. As a result, firms' actual profits, and thus household income (dividends) from the corporate sector, decline. Hence, an increase in the capital depreciation rate has two contradictory effects on banks' net foreign borrowing. On one hand, the reduction in investment reduces firms' demand for bank loans, decreasing banks' demand for foreign borrowing. On the other hand, the reduction in household income from the corporate sector reduces household deposits with banks and increases banks' demand for foreign borrowing. The net effect of the increase in d on the level of banks' net foreign borrowing seems to be in a decreasing direction. To bring the banks' demand for foreign borrowing back to the previous level, the estimated values of the 
parameters measuring the level of government subsidies or tax incentives (n) and the loan loss provisioning ratio (v) are adjusted downwards to decrease household deposits with banks and to increase banks' NPL losses, respectively.

4) An increase in the operating expense factor ( $\xi)$ leads to higher banks' NPL losses and higher banks' net foreign borrowing. To counter such an effect, the estimated value of the loan loss provisioning ratio (v) is adjusted upwards to reduce banks' NPL losses and their demand for foreign borrowing.

\section{5) An increase in the fraction of firms' investment financed by capital markets (cap)} leads to lower banks' lending to the corporate sector, thereby lowering banks' NPL losses and demand for foreign borrowing. Hence, the estimated value of the loan loss provisioning ratio (v) is adjusted downwards to balance such an effect.

6) An increase in the personal income tax rate $(\eta)$ reduces household income after tax, leading to a reduction in deposits with banks and greater banks' demand for foreign borrowing. The estimated value of the parameter measuring the level of government subsidies or tax incentives (n) therefore increases to bring the household income after tax and banks' net foreign borrowing back to the previous levels.

7) A decrease in the fraction of banks' cumulative NPL losses which are expected by foreign creditors to be covered by the country's international reserves $(\boldsymbol{\beta})$ reduces a credit cut by foreign creditors, $\left(F_{t}^{D}-\left(\varepsilon_{t} / P_{t}\right)\left(R_{t-1} / \beta\right)\right)$, and the amount of banks' NPL losses transferred to the government during a sudden stop, $\left\{1-\operatorname{inv}_{0}(1-\varphi)\right\}\left(\mathrm{F}_{\mathrm{t}}^{\mathrm{D}}-\left(\varepsilon_{\mathrm{t}} / \mathrm{P}_{\mathrm{t}}\right)\left(\mathrm{R}_{\mathrm{t}-1} / \beta\right)\right)$. Hence, the level of banks' net foreign borrowing declines less (increases) during the crisis. To counter such an effect, the estimated value of the loan loss provisioning ratio before the crisis $\left(v_{\text {sub1 }}\right)$ drops to increase the level of banks' cumulative NPL losses $\left(\mathrm{F}_{\mathrm{t}}\right)$ and the credit cut by foreign creditors. In addition, the estimated value of

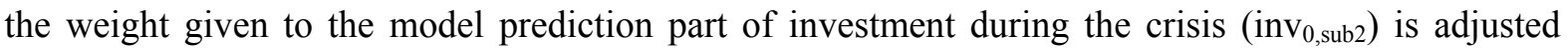


downwards to increase the amount of banks' NPL losses transferred to the government. These two adjustments cause the amount of banks' net foreign borrowing during the crisis to go down to the previous level.

8) An increase in the parameter determining the fraction of banks' cash shortfalls subsidized by the government $(\varphi)$ causes the amount of banks' NPL losses transferred to the government during a sudden stop, $\left\{1-\operatorname{inv}_{0}(1-\varphi)\right\}\left(\mathrm{F}_{\mathrm{t}}^{\mathrm{D}}-\left(\varepsilon_{\mathrm{t}} / \mathrm{P}_{\mathrm{t}}\right)\left(\mathrm{R}_{\mathrm{t}-1} / \beta\right)\right)$, to increase. To balance this effect, the estimated value of the loan loss provisioning ratio before the crisis $\left(v_{\text {sub1 } 1}\right)$ rises to reduce the level of banks' cumulative NPL losses $\left(\mathrm{F}_{\mathrm{t}}\right)$. In addition, the estimated value of the weight given to the model prediction part of investment during the crisis $\left(\operatorname{inv}_{0, \text { sub2 }}\right)$ is adjusted upwards to decrease the amount of banks' NPL losses transferred to the government during a sudden stop.

\subsubsection{Different Starting Values}

In optimization, a convergence to a local optimum rather than the global one is a potential problem. To examine this issue, the estimations with 648 different combinations of extreme starting values are conducted, and the results are found to be robust.

\subsubsection{Different Kernels and Bandwidth Parameters}

In an efficient GMM estimation, the optimal weighting matrix is the inverse of the covariance matrix of moment conditions, which is normally estimated using heteroskedasticity and autocorrelation consistent (HAC) approach. The HAC covariance matrix estimator depends on choices of kernels and bandwidth parameters. The GMM estimation in section 8.1 is conducted using Newey-West Bartlett kernel with the bandwidth parameter of 2 (i.e., the number of lags used is 1, consistent with the one-lag model). To explore if the results are robust to different choices of kernels, the estimations using Parzen and Quadratic Spectral kernels are carried out, and the results are mainly the same. The estimations using Bartlett kernel with different bandwidth parameters (bandwidth parameter $=3,4,5)$ are also conducted, and the main results are still maintained. 


\subsubsection{Different Breakpoints}

The results in section 8.1 are derived from the partial-sample GMM estimation with two known breakpoints. The first and the second breakpoints used are May 1997 and December 2000 since 16 finance companies' operations were suspended in June 1997 (which is considered the start of the crisis period) and the financial restructuring plan ended in December 2000 (which is considered the end of the crisis and the reform period). However, the sign of ailing financial institutions started to manifest in March 1997, as 10 finance companies were ordered by the Bank of Thailand to raise capital. Some may also argue that the crisis started in July 1997 after the exchange rate was floated. To test if the results are sensitive to different first breakpoints, the estimations using February 1997, March 1997, April 1997, and June 1997 as the first breakpoint are run, and the main results remain unchanged. 


\section{CHAPTER IX}

\section{SIMULATION}

In this chapter, the parameter values derived from the calibration and estimation ${ }^{18}$ in Chapter VIII are used to simulate endogenous variables under different moral hazard scenarios. The goal of these simulation exercises is to assess the impact of changes in the quality of institutions and domestic policies, as measured by changes in the degree of moral hazard problems, on the costs and benefits of international capital flows to an open country like Thailand.

\subsection{Costs and Benefits of International Capital Flows}

A central debate in the international finance literature is the magnitude of the benefits from international capital flows as they relate to capital available for real investment and higher output growth. Specifically, the benefits of greater investment must be weighed against the potentially large costs of international capital flows if a country relying more on foreign capital becomes significantly vulnerable to a crisis. A crisis not only creates large bailout costs to the government, but it also leads to output losses, especially when a sudden stop occurs in concurrence with a crisis. As suggested by Hutchison and Noy (2005), crises with sudden stops of capital flows have a larger negative impact on output growth than those without sudden stops.

In the model developed in Chapter IV, international capital flows via the banking sector serve as an additional source of financing for firms' investment. During good times (when there is no sudden stop), international capital flows, together with moral hazard problems at all levels, help fuel an economy and result in higher investment and output, which are considered the key benefits of the

\footnotetext{
${ }^{18}$ If the estimated value of parameter is not significantly different from zero, the value of zero will be used instead.
} 
capital flows. Nevertheless, the capital flows and the moral hazard problems also allow banks to accumulate losses (the moral hazard problem at the bank level) and excessively borrow from abroad (the moral hazard problems at the international level) as well as induce firms to overinvest and excessively borrow from banks (the moral hazard problem at the corporate level). An increasing volume of those excessive risk-taking activities makes a country more vulnerable to a sudden stop and a crisis, which normally result in substantial costs. Particularly, bank bailouts through transfers of bank losses to the government as a result of a crisis are considered the direct costs to a country. In addition, output losses as a result of credit cuts by foreign creditors during sudden stops are considered the indirect costs.

Hence, this model can be used to assess the effect of reductions in moral hazard problems (as a result of changes in the quality of institutions and domestic policies) on all key benefits and costs of international capital flows emphasized by prior literature. Particularly, the bailout costs (direct costs) and the changes in output (indirect benefits if positive or costs if negative) are estimated using the simulated data under different moral hazard scenarios.

\subsection{Conjectures about the Results}

Based on the mechanism of the model, the effects of changes in the quality of institutions and domestic policies on the direct and indirect costs of international capital flows to a country like Thailand can be conjectured as follows.

\section{1) An increase in the interest rate sensitivity to the aggregate level of banks' net foreign}

borrowing $\left(\psi_{1}\right)$, due to a plan to replace the blanket guarantee with a limited guarantee, could either positively or negatively impact an economy, depending upon the time-series pattern of the simulated series of banks' net foreign borrowing. If the simulated changes in the aggregate level of banks' net foreign borrowing are mostly negative (i.e., the banks' net foreign borrowing is most of the time decreasing), an increase in $\psi_{1}$ leads to a greater reduction in domestic interest rates. The greater reduction in the domestic interest rates as a result of the increase in $\psi_{1}$ benefits a country since it 
results in higher output and lower bailout costs. In contrast, if the simulated changes in the aggregate level of banks' net foreign borrowing are mostly positive, an increase in $\psi_{1}$ causes a larger increase in domestic interest rates, thereby lowering output and increasing bailout costs. This latter case could happen when the simulated economy starts with a low level of wealth or output and has to borrow from abroad for several periods. Since the data show that the actual changes in the aggregate level of banks' net foreign borrowing for Thailand are mostly negative during the sample period, January 1993 - June 2007, it is anticipated that the increase in $\psi_{1}$ will benefit the country by raising the output and reducing the bailout costs.

2) A reduction in the interest rate sensitivity to the world interest rate $\left(\psi_{0}\right)$, which occurs in conjunction with an increase in $\psi_{1}$, could either benefit or harm a country, depending upon the time-series pattern of the world interest rate. If changes in the world interest rate used in the simulations are mostly positive (i.e., the world interest rate is most of the time increasing), a decrease in $\psi_{0}$ causes domestic interest rates to increase less with the world interest rate. The lower domestic interest rates as a result of the decrease in $\psi_{0}$ benefit a country since they result in higher output (due to higher investment) and lower bailout costs (due to lower banks' NPL losses). On the other hand, if changes in the world interest rate are mostly negative (i.e., the world interest rate is most of the time decreasing), a decrease in $\psi_{0}$ causes domestic interest rates to decrease less with the world interest rate. The higher domestic interest rates as a result of the decrease in $\psi_{0}$ cause a reduction in output and an increase in bailout costs. Since the actual changes in the world interest rate during the sample period are mostly positive, it is expected that the decrease in $\psi_{0}$ will benefit the country by increasing the output and lowering the bailout costs.

3) An increase in the banks' loan loss provisioning ratio (v) as a result of improved banking supervision leads to a lower level of banks' cumulative NPL losses, thereby lowering bailout costs. The lower level of banks' cumulative losses also results in a smaller credit cut by the foreign 
creditors during a sudden stop, thereby mitigating a reduction in firms' investment and resulting in a lower reduction (or an increase) in output during the crisis.

4) A decrease in the level of government subsidies or tax incentives (n) leads to a reduction in firms' expected profits. Therefore, firms reduce their investment, resulting in lower output. This conjecture is consistent with the view by Stiglitz (2002), in which contractionary fiscal policies during crises, especially the Asian financial crisis, have adverse effects on crisis countries since they make serious recessions even deeper. Firms also reduce their demand for bank loans, as a result of the decrease in n, leading to lower banks' NPL losses and lower bailout costs.

\section{5) A decrease in the expected exchange rate deviation from the uncovered interest rate} parity (UIP) $\left(\mathbf{P}_{\varepsilon}\right)$ as a result of an implementation of a more flexible exchange rate regime leads to a higher real exchange rate (local currency depreciation). As a result, the value of the country's international reserves (liquid foreign assets) in local currency increases, resulting in a smaller cut in credit by foreign creditors during a sudden stop. Hence, there will be a smaller cut in investment by firms, leading to a lower reduction (an increase) in output, a smaller decrease (an increase) in banks' lending and NPL losses, and thus an increase in bailout costs during a sudden stop. However, the decrease in $\mathrm{P}_{\varepsilon}$ directly affects the output and the bailout costs only when there is a sudden stop. Hence, the direct effects of the decrease in $\mathrm{P}_{\varepsilon}$ on the total output and the total bailout costs are expected to be quite small.

\subsection{Scenarios}

The analysis in this section covers four groups of scenarios, as described in detail in Table 9. The base scenario serves as the benchmark case where the moral hazard problems at all levels are severe (i.e., the quality of institutions and domestic policies are still poor) as all parameter values $\left(v, \mathrm{n}, \Psi_{0}, \Psi_{1}, \mathrm{P}_{\varepsilon}, \operatorname{Inv}_{0}, \mathrm{Inv}_{1}\right)$ are set at the pre-crisis levels. Group A scenarios facilitate a 'what if' analysis when only one aspect of the moral hazard problems (i.e., the quality of institutions and 
domestic policies with respect to a moral hazard problem) is adjusted to the post-crisis level. In Group B scenarios, it is assumed that parameter v, which measures the moral hazard problem at the bank level, and another aspect of the moral hazard problems are concurrently adjusted to the postcrisis levels. This is to examine if there are additional benefits and costs from addressing two aspects of the moral hazard problems at the same time. Scenario $\mathrm{C} 1$ uses different parameter values (as derived from the partial-sample GMM estimation) for each sub-period. This scenario should therefore reflect the situation closest to what has happened in Thailand.

\subsection{Assumptions}

As the parameter values are estimated using first difference equations, the series of endogenous variables are also simulated (in changes) using the modified equilibrium relations in Appendix E. The series of variables in levels are then computed using specified initial values.

For stock variables and flow variables which have their own lagged variables on the right hand side of the equations (i.e., capital stock (K), investment (I), banks' net foreign borrowing (b), real exchange rate $(\varepsilon / \mathrm{P})$, consumption $(\mathrm{C})$, and real monetary aggregate $(\mathrm{M} / \mathrm{P}))$, the actual values for January 1993 are used as the initial values. Simulated values are used for flow variables which do not have their own lagged variables on the right hand side of the equations (i.e., output (Y)).

For exogenous variables, the actual series of NPL ratios, inflation rates, world interest rates, employed labor, and international reserves are utilized, rather than simulating them using AR(1) processes. This is to create the scenarios as close as possible to what has happened in Thailand during 1993-2007. The eleven-year moving average of monthly interest rates (used in the equations of the change in $\mathrm{M} / \mathrm{P}$, the change in $\mathrm{C}$, and the change in $\mathrm{I}$ ) is computed from the sum of the past actual interest rates plus the simulated interest rate for the current period. 


\subsection{Simulation Results}

Table 10 presents the magnitude of the estimated direct and indirect costs for each scenario, in comparison with the actual data. The estimated direct costs (bailout costs) are the sum of banks' NPL losses transferred to the government while the actual direct costs are the sum of actual government lending to the Financial Institutions Development Funds (FIDF). ${ }^{19}$ The estimated indirect costs in this table are demonstrated in terms of the average annual traded output (output) and the average annual output growth over February 1993 - June 2007 for comparison with commonly used data. The direct costs and the average annual output are also reported as future values in June 2007 to account for the time value of money.

\section{Direct Costs}

The direct costs estimated from the model range from $0 \%$ of output in scenario A1, B1, B2 and B3 (when there is no moral hazard problem at the bank level) to $18.02 \%$ of output or $21.56 \%$ of output (in future value) in scenario $\mathrm{C} 1$ when different parameter values for each sub-period are used. This range overlaps with the estimated bailout costs of over $20 \%$ of output by Kaminsky and Reinhart (1998). However, when compared with the actual bailout costs $(32.69 \%$ of output or $36.78 \%$ of output in future value) and the estimated costs of restructuring and recapitalizing the banking system (35\% of GDP) by Burnside et al. (2000), the direct costs estimated from this model are much lower. This is largely due to the implicit assumption that the principal part of loans granted to the corporate sector is fully collateralized. Hence, banks' NPL losses estimated from the model do not include losses from the principal part. In reality, although loans had been fully collateralized at the origination, the value of collaterals pledged against those loans dropped significantly during the crisis. In addition, there is no run by domestic depositors in this model. Hence, banks in this model may face smaller cash shortfalls during a sudden stop than when there is also a run by domestic depositors,

\footnotetext{
${ }^{19}$ Data on government lending to the Financial Institutions Development Funds (FIDF) are obtained from the Bank of Thailand.
} 
which is often observed in crisis countries including Thailand. This could be another reason for obtaining the estimated direct costs lower than the actual ones.

Scenario $\mathrm{C} 1$ provides the highest estimate of the direct costs, since it allows all parameters to be different across sub-periods and to reflect the worse-than-expected economic downturns during the crisis period. Scenario A4 and the base scenario provide, although not much different, the second and third highest estimates. As expected, the base case, in which all types of moral hazard problems are assumed to be at the pre-crisis levels, generates high direct costs. However, scenario A4 yields the results not much different from the base case. This suggests that the change in the expected exchange rate deviation from the UIP (the change in $\mathrm{P}_{\varepsilon}$ from 0.0044 in the base case to 0 in scenario A4), which may result from the change in an exchange rate regime, does not help reduce the bailout costs when other moral hazard problems are still severe. ${ }^{20}$

Consistent with the analysis of the model in Chapter IV, what seems to matter most to the direct costs is the moral hazard problem at the bank level. Once the loan loss provisioning ratio (v) is set at $100 \%$ (scenario A1), i.e., there is no accumulation of NPL losses in banks, the direct costs are estimated to be zero. The improvement in foreign investors' estimation of risks associated with their lending to the banking sector in Thailand (i.e., the changes in $\Psi_{0}$ from 1.18 to 0 and $\Psi_{1}$ from 0 to 1.46 in scenario A3), which makes it more expensive for banks to increase their foreign borrowing, also reduces the bailout costs substantially from $14.12 \%$ in the base case to $6.11 \%$ of output in future value. However, the reduction in government subsidies or tax incentives to the corporate sector (the change in $\mathrm{n}$ from -3.84 to -29.02 in scenario A2), which leads to lower investment and lower bank lending to the corporate sector, plays a very small role in reducing the bailout costs. Relative to the base case, the direct costs in this scenario only decline by $0.17 \%$ of output in future value.

\footnotetext{
${ }^{20}$ According to the mechanism of the model, a decrease in $\mathrm{P}_{\varepsilon}$ leads to a depreciation in the real exchange rate, an increase in the value of international reserves in local currency, and a reduction in a credit cut by foreign creditors (the difference between banks' cumulative losses and the value of international reserves) in the same period. This causes investment to decline less when there is a sudden stop, resulting in higher banks' lending to the corporate sector and higher banks' cumulative NPL losses in the next period.
} 


\section{Indirect Costs or Benefits}

As emphasized by several researchers, international capital flows, together with moral hazard problems, lead to an increase in investment and output, especially during a boom, as well as trigger a crisis. In addition to bailout costs, a sudden stop of capital flows may cause a deeper recession or a substantial reduction in output during and after a crisis. The changes in output are thus a measure of the indirect costs (if negative) or benefits (if positive) of international capital flows to a country.

In Table 10, the indirect costs or benefits are analyzed in terms of the average annual output and the average annual output growth rate. The estimated average output ranges from 2.92 to 3.10 trillion baht. This range covers the average actual output over February 1993 - June 2007 of 2.94 trillion baht. However, the estimated average output growth rate is between $2.06 \%$ and $3.21 \%$ per annum, which is much lower than the actual output growth rate of $4.40 \%$ per annum.

When comparing across scenarios, in almost all the scenarios, except scenarios A2 ( $\mathrm{n}$ at the post-crisis level), B1 ( $v$ and $\mathrm{n}$ at the post-crisis levels) and $\mathrm{C} 1$ (all parameters at the post-crisis levels), the average output is slightly higher than, and the average output growth rate is almost the same as, those in the base case. On the other hand, scenarios A2, B1 and C1, in which the level of government subsidies (or taxes if negative) (n) is set at the post-crisis level, demonstrate the substantially lower average output and average output growth rate. These results suggest that the reduction in government subsidies or tax incentives to the corporate sector, which leads to lower investment and lower bank lending to the corporate sector, though slightly helps reduce the bailout costs, creates the substantial indirect costs to the country by lowering the average output and the average output growth rate.

\section{Total Costs and Benefits}

To have a complete picture of which policy combinations would benefit the country the most under the selected simulated scenarios, the direct and indirect costs are simultaneously analyzed. 
Here the indirect costs are analyzed in term of the sum of the output over the sample period, rather than the average, so that it can be added to the direct costs (which are the sum of the bailout costs over the same period) to obtain the total costs. In addition, the direct, indirect, and total costs are relative to those in the base case for better comparison. Results are presented in Table 11.

Considering the total costs among all of the group A scenarios, the results are as conjectured. The increase in the loan loss provisioning ratio to $100 \%$ (scenario A1) has the largest benefit since it directly and substantially reduces the bailout costs as well as slightly helps increase the output. The improvement in foreign investors' estimation of risks (scenario A3) also has a significant positive impact on both the direct and indirect costs. Nevertheless, the reduction in government subsidies or tax incentives (scenario A2) hurts, rather than benefits, the country since it leads to a substantial decline in the output. In addition, the reduction in the expected exchange rate deviation from the UIP (scenario A4) does not have a significant effect as anticipated.

These results indicate that, in a typical bank-based open economy, the moral hazard problem at the bank level plays a key role in creating the bailout costs. Hence, the first priority should be given to the improvement in the quality of institutions or domestic policies, which could potentially help reduce the moral hazard problem at the bank level, such as the improvement in banking supervision. Group B scenarios combine the policies to improve banking supervision (aiming to resolve the moral hazard problem at the bank level) with another set of policies (aiming to reduce another level of the moral hazard problems) to examine whether there are additional costs or benefits from implementing two sets of policies together. The simulation results for scenario B1 suggest that the combination of the improved banking supervision and the reduction in government subsidies or tax incentives hurts the economy. Although the implementation of stricter loan loss provisioning rules significantly reduces the bailout costs, the reduction in government subsidies or tax incentives results in the substantially lower output. On the other hand, the results for scenario B2 suggest that the net benefit from implementing the policies to improve banking supervision together with those to 
improve foreign investors' estimation of risks is larger than when each set of policies is implemented alone (scenario A1 or A3). The impact of the policies to improve the expected exchange rate deviation from the UIP, either implemented alone (scenario A4) or with the policies to improve banking supervision (scenario B3), is minimal.

In conclusion, the results from the simulation exercises suggest that the combination of the policies to improve banking supervision and those to improve foreign investors' estimation of risks is most beneficial to a country like Thailand under the selected simulated scenarios. In contrast, the policies to reduce government subsidies or tax incentives to the corporate sector hurt the country by substantially lowering the output. This result seems to be consistent with the view by Stiglitz (2002), who argues that tightening fiscal policies during crises have adverse impacts on crisis countries since they make serious recessions even deeper.

\subsection{Sensitivity Analysis}

The simulation exercises in section 9.5 consider only a certain number of scenarios. In most of the scenarios considered, except scenario B2, the interest rate sensitivity to the aggregate level of banks' net foreign borrowing $\left(\psi_{1}\right)$ is set at the pre-crisis level which is zero. Hence, any change that affects banks' net foreign borrowing does not have any impact on domestic interest rates. When $\psi_{1}$ is greater than zero, there might be additional effects of changes in the quality of institutions and domestic policies via the interest rate channel. Therefore, it might be interesting to examine those additional effects when the policies to improve the moral hazard problem at each level are implemented under the condition that the interest rate channel is working (i.e., $\psi_{1}$ is greater than zero). In addition, since the results in section 9.5 are based on exogenously-determined parameters, it would be interesting to examine how the simulation results are impacted by a change in each of the exogenously-determined parameters both directly and indirectly through the interest rate mechanism. 
This section first describes the role of the domestic interest rates as the mechanism through which any change affecting some parts of an economy is transmitted to the other parts. Then it examines the additional effects when the policies to reduce each level of the moral hazard problems are implemented under the condition that the interest rate channel is working. Finally, it explores how the simulation results are affected by a change in each of the exogenously-determined parameters both directly and indirectly via the interest rate mechanism.

\subsubsection{Interest Rate Mechanism}

The equilibrium conditions of the model suggest that the domestic real interest rate $\left(\mathrm{r}_{\mathrm{t}}\right)$ affects the decisions of all agents in an economy. Particularly, the firms' level of capital stock (K), money holdings by households (M), and current consumption relative to future consumption of households $\left(\mathrm{C}_{\mathrm{t}} / \mathrm{C}_{\mathrm{t}+1}\right)$ decrease with the domestic real interest rate. In addition, dividends paid by banks to their shareholders (X) from performing loan (PL) profits increase with the domestic real interest rate. Those decisions determine the output $(\mathrm{Y})$, the amount of government subsidies or taxes to the corporate sector (S), the amount of bank lending to the corporate sector (e), the amount of deposits from the household sector (a), as well as the aggregate level of banks' net foreign borrowing (b). At the same time, the domestic real interest rate (r) is also determined by the aggregate level of banks' net foreign borrowing (b). Hence, any change that affects the aggregate level of banks' net foreign borrowing (b), either directly or indirectly through the variables $\{\mathrm{K}, \mathrm{M}, \mathrm{C}, \mathrm{X}, \mathrm{Y}, \mathrm{S}, \mathrm{e}, \mathrm{a}\}$, will have additional impacts on the whole economy through the domestic real interest rate $(r)$.

How well this interest rate mechanism works however depends on the value of parameter $\psi_{1}$. Recall that $\psi_{1}$ measures the interest rate sensitivity to the aggregate level of banks' net foreign borrowing. Hence, the higher the value of $\psi_{1}$, the greater the additional impacts of a change in one of the endogenous variables on the whole economy via the interest rate channel. However, when $\psi_{1}$ is zero, this channel is cut, and there is no additional effect via the interest rate channel. 


\subsubsection{Additional Effects When $\psi_{1}$ is Greater than Zero}

This section examines the additional effects (via the interest rate channel) of changes in the quality of institutions and domestic policies to mitigate moral hazard problems on the direct and indirect costs of international capital flows when $\psi_{1}$ is greater than zero.

\section{1) An increase in the loan loss provisioning ratio (v)}

The simulation results for scenario A1 in section 9.5 suggest that an increase in the loan loss provisioning ratio (v), when $\psi_{1}$ is set at the pre-crisis level (i.e., zero), benefits a country like Thailand by substantially lowering bailout costs and slightly increasing output. In addition to these direct effects, a smaller cut in credit by foreign creditors as a result of the higher loan loss provisioning ratio causes banks' net foreign borrowing (b) to decrease less during a sudden stop. When $\psi_{1}$ is greater than zero, the lower reduction (or the increase) in b causes the domestic real interest rate (r) to go up, leading to lower output and higher bailout costs. The counter indirect effect from the increase in the loan loss provisioning ratio on the bailout costs is however much smaller than the positive direct effect. Hence, when combined with the direct effects, the increase in the loan loss provisioning ratio leads to the much lower bailout costs; however, the output slightly decreases.

In scenario B2 when the policies aiming to improve banking supervision (an increase in v) and those aiming to improve foreign creditors' estimation of risks (a reduction in $\psi_{0}$ and an increase in $\psi_{1}$ ) are implemented together, the country benefits more from the lower bailout costs and the higher output than when each set of policies is implemented alone. This is because the positive direct effects from the increase in the loan loss provisioning ratio, the increase in $\psi_{1}$ (when changes in $\mathrm{b}$ are mostly negative), and the decrease in $\psi_{0}$ (when changes in the world interest rate are mostly positive) more than outweigh the negative indirect effects via the interest rate channel of the increase in the loan loss provisioning ratio. 


\section{2) A reduction in the level of government subsidies or tax incentives (n)}

The simulation results for scenario A2 in section 9.5 indicate that a decrease in the level of government subsidies or tax incentives (n), when $\psi_{1}$ is set at zero, leads to much lower output (due to lower investment) and slightly lower bailout costs (due to lower bank lending to the corporate sector). Apart from these direct effects, the decrease in the government subsidies or tax incentives and the lower output reduce firms' profits and dividends paid by firms to households. With lower income, households deposit less money in banks, resulting in higher banks' demand for foreign borrowing. When $\psi_{1}$ is greater than zero, the higher level of banks' net foreign borrowing causes the domestic real interest rate (r) to increase, leading to a further reduction in investment and output as well as an increase in bailout costs. The negative indirect impact (via the increase in $r$ ) of the decrease in $n$ on the bailout costs is stronger than the positive direct impact (via the reduction in investment and thus bank lending to the corporate sector). Hence, when the interest rate mechanism is working ( $\psi_{1}$ is greater than zero), the decrease in the government subsidies or tax incentives leads to even greater negative impacts on the economy through the greater reduction in the output and the higher bailout costs.

\section{3) A decrease in the expected exchange rate deviation from the uncovered interest rate}

\section{parity $\left(\mathbf{P}_{\varepsilon}\right)$}

A decrease in the expected exchange rate deviation from the UIP $\left(\mathrm{P}_{\varepsilon}\right)$, when $\psi_{1}$ is zero, has a minimal impact on output and bailout costs, as suggested by the results for scenario A4 in section 9.5. However, when the interest rate mechanism is working (when $\psi_{1}$ is greater than zero), a local currency depreciation as a result of the lower $\mathrm{P}_{\varepsilon}$ reduces the value of banks' net foreign borrowing in foreign currency (b). Hence, when the simulated changes in banks' net foreign borrowing are mostly negative, the local currency depreciation causes a lower reduction in banks' net foreign borrowing, leading to a lower reduction (an increase) in the domestic real interest rate. The increase in the domestic real interest rate as a result of the lower $\mathrm{P}_{\varepsilon}$ in this case causes lower output and higher 
bailout costs. On the other hand, when changes in banks' net foreign borrowing are mostly positive, the local currency depreciation causes a lower rise in banks' net foreign borrowing, leading to a smaller increase (a decrease) in the domestic real interest rate. The decrease in the domestic real interest rate as a result of the lower $\mathrm{P}_{\varepsilon}$ brings about higher output and lower bailout costs in this case. Therefore, when the interest rate channel is working, the decrease in $\mathrm{P}_{\varepsilon}$ benefits the country only in the situation where the country is most of the time the net foreign borrower, i.e., when changes in banks' net foreign borrowing are mostly positive.

\subsubsection{Changes in Exogenously-Determined Parameters}

This section examines how sensitive the simulation results are to a change in each of the exogenously-determined parameters both in the cases where $\psi_{1}$ is zero and $\psi_{1}$ is greater than zero.

\section{1) A decrease in households' degree of (liquidity) risk aversion $(\chi)$}

A decrease in households' degree of risk aversion $(\chi)$ causes a decline in both the level and the magnitude of a change in households' demand for money holdings, which has no direct effect on output or bailout costs. However, when $\psi_{1}$ is greater than zero, the lower level of households' money balances as a result of the decrease in $\chi$ leads to higher households' deposits with banks and lower banks' demand for foreign borrowing. The reduction in banks' net foreign borrowing leads to a decrease in the domestic real interest rate, resulting in higher output and lower bailout cost. Hence, the decrease in households' degree of (liquidity) risk aversion benefits the country through the interest rate mechanism by increasing the total output and lowering the bailout costs.

\section{2) An increase in the production technology factor (A) and a rise in the income share of}

\section{capital $(\alpha)$}

Both an increase in the production technology factor (A) and a rise the income share of capital $(\alpha)$ result in higher output, providing a greater incentive for firms to increase their investment. 
Banks' lending to the corporate sector increases, as a result of the higher investment, leading to higher banks' NPL losses and higher bailout costs.

When $\psi_{1}$ is greater than zero, there are two additional effects via the interest rate mechanism. First, the higher output as a result of the higher A or $\alpha$ leads to higher firms' profits and higher dividends paid by firms to households. With higher income, households deposit more money in banks, reducing banks' demand for foreign borrowing (b) and causing the domestic real interest rate to go down. Hence, investment and output increase and bailout costs decrease. Second, the higher investment as a result of the higher A or $\alpha$ causes firms to increase their demand for bank loans, increasing banks' demand for foreign borrowing and driving the domestic real interest rate up. As a result, output declines and bailout costs rise. If the simulated economy starts with a high level of wealth or output, the increase in A or $\alpha$ leads to a bigger rise in output and the first additional effect seems to dominate the second one. Hence, output increases and bailout costs decrease (even after combining with the negative direct effect from the higher bailout costs) in this case. On the other hand, if the simulated economy starts with a low level of wealth or output, the increase in A or $\alpha$ leads to a smaller increase in output and the second additional effect may outweigh the first one. In this case, output decreases (increases less when combined with the direct effect) and bailout costs rise.

\section{3) An increase in the capital depreciation rate (d)}

A higher capital depreciation rate (d) increases firms' expenses and reduces firms' expected profits, causing firms to lower their investment and their demand for bank loans. This leads to lower output and lower bailout costs.

When $\psi_{1}$ is greater than zero, there are two additional effects via the interest rate channel. First, the increase in firms' expenses and the decrease in firms' output as a result of the higher capital depreciation rate reduce the amount of dividends paid by firms to households. With lower income, households reduce their deposits with banks, causing banks to increase their demand for foreign borrowing (b). The higher $\mathrm{b}$ causes the domestic real interest rate to go up, leading to lower output 
and higher bailout costs. Second, the decrease in firms' investment and their demand for bank loans reduces banks' demand for foreign borrowing, causing the domestic real interest rate to decline. As a result, output increases and bailout costs decrease. If the simulated economy starts with a high level of wealth or output, the increase in d leads to a larger decrease in output and the first additional effect is stronger than the second one. Hence, output decreases, and bailout costs increase (decrease less when combined with the direct effect) in this case. On the other hand, if the simulated economy starts with a low level of wealth or output, the increase in d leads to a smaller decrease in output and the second additional effect dominates the first one. Therefore, output increases (decreases less when combined with the direct effect) and bailout costs decrease in this case.

\section{4) An increase in the operating expense factor $(\xi)$}

A rise in banks' operating expenses (as measured by $\xi$ ) increases banks' losses from NPLs, resulting in higher bailout costs. Banks also charge higher lending rates to firms to cover their higher expenses, causing firms to lower their investment. As a result, output declines.

The increase in banks' NPL losses as a result of the higher $\xi$ leads to a larger credit cut by foreign creditors, leading to a greater reduction in banks' net foreign borrowing during a sudden stop. When the interest rate mechanism is working, the greater reduction in banks' net foreign borrowing causes the domestic real interest rate to sharply decline, leading to an increase (a smaller decrease when combined with the direct effect) in investment and output as well as a reduction in bailout costs (even after combining with the negative direct effect from the higher bailout costs).

\section{5) An increase in the fraction of firms' investment financed by capital markets (cap)}

A greater fraction of firms' investment financed by capital markets (cap) leads to a reduction in banks' lending to the corporate sector, a decrease in banks' NPL losses, and lower bailout costs. The lower level of banks' NPL losses also causes a smaller credit cut by foreign creditors during a sudden stop, resulting in a lower reduction (a slight increase) in output. 
The smaller credit cut by foreign creditors during a sudden stop as a result of the higher cap results in a smaller decrease (an increase) in banks' net foreign borrowing. When the interest rate mechanism is working, the increase in banks' net foreign borrowing causes the domestic real interest rate to go up, leading to a decrease in output (even after combining with the positive direct effect from the slightly higher output) and a rise (a smaller decrease when combined with the direct effect) in bailout costs.

\section{6) An increase in the personal income tax rate $(\eta)$}

A higher personal income tax rate does not have any direct effect on output or bailout costs. However, such a change leads to lower household income after tax, causing households to deposit less money in banks. This causes banks to increase their demand for foreign borrowing. When $\psi_{1}$ is greater than zero, the higher level of banks' net foreign borrowing causes the domestic real interest rate to go up, resulting in higher bailout costs and lower output.

\section{7) An increase in the time preference factor $(\delta)$}

An increase in the time preference factor has no direct impact on output or bailout costs. This change however causes a reduction in household consumption, leading to a greater amount of household deposits with banks and lower banks' demand for foreign borrowing. When the interest rate mechanism is working, the decrease in banks' net foreign borrowing causes a reduction in the domestic real interest rate, leading to lower bailout costs and higher output.

8) An increase in the weight given to contemporary investment predicted by the model (inv $v_{0}$ ) and a decrease in the weight given to lagged investment (inv $\left.v_{1}\right)$ lead to a decrease in investment because contemporary investment predicted by the model (the model prediction part) is generally lower than lagged investment (the lagged part). The lower investment results in lower output and lower demand for bank loans. Hence, this change in the relative weight between the model prediction part and the lagged part results in lower output as well as lower bailout costs. 
The increase in the weight given to the model prediction part $\left(\operatorname{inv}_{0}\right)$ also leads to a larger cut in credit by banks to firms during a sudden stop. ${ }^{21}$ The reduction in banks' lending causes banks' demand for foreign borrowing and thus the domestic real interest rate to go down. As a result, output increases (decreases less when combined with the direct effect) and bailout costs decrease.

9) A decrease in the fraction of banks' cumulative losses which are expected by foreign creditors to be covered by the country's international reserves ( $\beta$ ) leads to a smaller cut (an increase) in credit by foreign creditors during a sudden stop. As a result, there will be a smaller cut in banks' lending to the corporate sector and a lower reduction in investment, leading to higher bailout costs and higher output.

Additionally, when the interest rate mechanism is working, the smaller cut in credit by foreign creditors as a result of the decrease in $\beta$ causes a smaller reduction (an increase) in banks' net foreign borrowing. Consequently, the domestic real interest rate decreases less (increases), leading to much higher bailout costs and lower output (even after combining with the positive direct effect from the higher output).

10) An increase in the parameter determining the fraction of banks' cash shortfalls subsidized by the government during a sudden stop $(\varphi)$ reduces a cut in credit by banks to the corporate sector. This change leads to a smaller reduction (an increase) in firms' investment, an increase in output, an increase in banks' lending, as well as a slight increase in banks' losses transferred to the government during a sudden stop. However, the remaining banks' cumulative NPL losses which are transferred to the government after the sudden stop are lower. The net effect of the increase in $\varphi$ is thus a small reduction in bailout costs and a small increase in output.

When the interest rate mechanism is working, there are two additional indirect effects via the interest rate channel. First, the smaller cut in credit by banks to the corporate sector and the smaller

\footnotetext{
${ }^{21} \mathrm{~A}$ cut in credit by banks to firms during a sudden stop is equal to $\operatorname{inv}_{0}(1-\varphi)\left(\mathrm{F}_{\mathrm{t}}^{\mathrm{D}}-\left(\frac{\varepsilon_{\mathrm{t}}}{\mathrm{P}_{\mathrm{t}}}\right)\left(\frac{\mathrm{R}_{\mathrm{t}-1}}{\beta}\right)\right)$.
} 
reduction in firms' investment, as a result of the increase in $\boldsymbol{\varphi}$, lead to a smaller reduction (an increase) in banks' lending to firms and greater banks' demand for foreign borrowing. Hence, the domestic interest rate increases, leading to lower output and higher bailout costs. Second, the smaller reduction (the increase) in output as a result of the increase in $\varphi$ increases firms' profits and dividends paid by firms to households. Households therefore deposit more money in banks, lowering banks' demand for foreign borrowing and causing the domestic real interest rate to go down. This second indirect effect, in contrast to the first indirect effect, causes output to increase and bailout costs to decrease. Combined with the direct effects, the net effects of the increase in $\boldsymbol{\varphi}$ when $\psi_{1}$ is greater than zero seem to be an increase in both output and bailout costs. However, the magnitudes of those effects are small. 


\section{CHAPTER X}

\section{MISSING COMPONENTS OF THE MODEL AND AREAS FOR FUTURE RESEARCH}

The model developed in this dissertation provides a unifying framework for analyzing the relationships between international capital flows via the banking sector and other sectors of an economy when moral hazard problems are present. Although the model is rich in several dimensions, there are some simplifying assumptions and missing components, which could be areas for future research.

\section{(1) Fully Collateralized Loans}

In this model, the sum of the value of bank debt and the cumulative amount of additional bonds or stocks issued by firms to finance new investment is always equal to the value of firms' capital stock. It is therefore implicitly assumed that the principal amount of a loan is fully collateralized. In reality, this may not be the case. Although at the origination of a loan, the collateral value is normally greater than the principal amount of the loan, the collateral value can shrink over time, especially during an economic decline or during a crisis. Therefore, banks' NPL losses suggested by the model include only the interest part, not the principal part of loans, and the bailout costs estimated by the model are lower than actual costs.

\section{(2) No Run by Domestic Depositors}

A crisis in this model is triggered by a sudden stop of international capital flows (or a run by foreign creditors). It is assumed that there is no run by domestic depositors (although a credit cut by foreign creditors causes the deposit rate to decrease, leading to lower household deposits with banks). 
Banks in this model therefore encounter smaller cash shortfalls during a sudden stop. Hence, the estimated bailout costs and the reduction in bank lending to the corporate sector during a sudden stop suggested by the model may be smaller than what actually happens during a crisis.

\section{(3) Exogenous Non-Performing Loans to Total Loans Ratio}

It is assumed in the model that the fraction of low-type firms or the non-performing loans to total loans ratio (NPL ratio) is exogenous. Hence, the model allows the NPL ratio to affect endogenous variables in the model, but does not allow other variables to affect the NPL ratio. Nevertheless, the model can be extended by endogenizing the NPL ratio. One way to do this is by assuming that firms are endowed with different levels of production technology (determined by parameter $A_{t}$ ). For example, $A_{t}$ may be assumed to be uniformly distributed within the range

$(\underline{A}, \bar{A})$. Let $A_{t}^{o}$ be the cutting point where a firm with the level of production technology equal to $\mathrm{A}^{\mathrm{o}}{ }_{\mathrm{t}}$ will be able to produce and sell just enough output to break even. Note that $\mathrm{A}_{\mathrm{t}}^{\mathrm{o}}$ can be backed out from the profit function of a firm, and it is endogenous. Hence, firms having the level of production technology lower than $\mathrm{A}_{\mathrm{t}}^{\mathrm{o}}$ are not able to service debt and thus are classified as non-performing loans. Hence, the NPL ratio at time $t$ can be defined as the ratio of firms having the level of production technology lower than $\mathrm{A}_{\mathrm{t}}^{\mathrm{o}}=\frac{\mathrm{A}_{\mathrm{t}}^{\mathrm{o}}-\underline{\mathrm{A}}}{\overline{\mathrm{A}}-\underline{\mathrm{A}}}$.

\section{(4) Role of Bank Foreign Exchange Hedging}

In this model, it is assumed that banks do not hedge the foreign exchange risk associated with their foreign borrowing. This assumption is reasonable for many crisis countries since rigid exchange rate regimes before the crises were common. Hence, there had been a widely held perception that the governments of those countries were committed to stable exchange rates. Nevertheless, this assumption can be relaxed by introducing additional parameters, e.g., a hedging ratio and hedging cost factor, at the expense of having a more complicated model. Besides having more parameters to 
be calibrated or estimated, the hedging cost will be an additional cost of banks' foreign borrowing and will therefore play a role in determining the domestic interest rates.

\section{(5) Other Possible Model Extensions}

(5.1) More active role by households: Households only make decisions on consumption, money holdings, and deposits with banks. There is no active portfolio management decision in this model.

(5.2) Incorporation of non-traded sector: There is only one traded sector in this model. Hence, the one-sector model may be extended to a two-sector model by incorporating both traded and non-traded sectors.

(5.3) Currency mismatches in the corporate sector: In this model, firms only borrow in local currency. It may be interesting to extend the model by allowing firms to borrow in both local and foreign currencies to examine the role of currency mismatches in the corporate sector in triggering or exacerbating a crisis. Allayannis, Brown, and Klapper (2003) examine the factors determining the use of different types of debt for East Asian non-financial firms as well as the effect

of debt type on firms' performance. They find no evidence that unhedged foreign currency debt is associated with significantly worse performance during the Asian financial crisis. 


\section{CHAPTER XI}

\section{CONCLUSION}

This dissertation studies the transmission mechanism of international capital flows via the banking sector to the real sector when moral hazard problems are present. The model developed in this dissertation describes a bank-based open economy much like those in Asia, Latin America, etc. and in particular the role of the quality of institutions and domestic policies in (i) reducing moral hazard problems and (ii) determining the net benefit of international capital flows to a country in the long run.

The theoretical model to explain such a mechanism is developed under a general equilibrium framework with three main ingredients reflecting the key observations of open countries which have experienced crises. First, the banking sector plays a major role in channeling international capital flows to the real sector. Second, there are structural and policy distortions, resulting in three layers of moral hazard problems in an economy before a crisis: (1) lax loan loss provisioning rules and inadequate banking supervision leading to excessive lending, excessive foreign borrowing, and an accumulation of NPL losses at the bank level, (2) government subsidies or tax incentives leading to overinvestment at the corporate level, and (3) expected government guarantees and stable exchange rates leading to excessive lending by foreign investors to the banking sector in another country, foreign investors' underestimation of risks, and a greater expected exchange rate deviation from the uncovered interest rate parity at the international level. Third, a sudden stop of capital flows is triggered when the expected level of the government's contingent liabilities exceeds the level of the country's international reserves. 
The model explains what has happened in many open countries which have experienced crises really well. In particular, this model shows that more available capital from international capital flows via the banking sector, together with the three layers of moral hazard problems, leads to excessive foreign borrowing and risk-taking behavior not only in the banking sector, but also in the real sector. The increasing level of foreign borrowing and cumulative losses as a result of risk-taking activities takes the economy away from its equilibrium. Once the level of cumulative losses reaches a certain threshold, foreign investors stop lending to the country and a sudden stop of capital flows occurs. This model therefore highlights the role of international capital flows and moral hazard problems in fueling an open economy during a boom as well as making a country more vulnerable to a sudden stop and a crisis.

This dissertation also finds that the quality of institutions and domestic policies matters. In examining the role of changes in the quality of institutions and domestic policies in mitigating moral hazard problems and in determining the net benefit of international capital flows, the parameters measuring the severity of moral hazard problems are estimated to fit Thailand data using the equilibrium conditions derived from the model. These parameter values are found to be significantly different before and after the crisis, with the values after the crisis showing significant reductions in the moral hazard problems at all levels. In addition, the results from the simulation exercises suggest that the policies to increase the effectiveness of banking supervision and those to improve foreign investors' estimation of risks, especially when implemented together, significantly help increase the net benefit of international capital flows by increasing the output and reducing the bailout costs. However, the policies to reduce government subsidies or tax incentives to the corporate sector hurt, rather than benefit, the country, as the cost from the lower output exceeds the benefit from the lower bailout costs. 
In conclusion, policies to reduce a moral hazard problem in a particular sector not only have an immediate impact on that particular sector, but also affect other sectors as well as the whole economy in the long run. Furthermore, some policy combinations are better than others in different situations. Therefore, it is very important that policy makers and related authorities coordinate with one another to come up with the best set of policies for the whole country. 


\section{APPENDIX A}

\section{Equilibrium Conditions}

\section{Corporate Sector}

In aggregate, the total capital stock $\left(\mathrm{K}_{\mathrm{t}}\right)=\mathrm{N} \mathrm{k}$, the total employed labor $\left(\mathrm{L}_{\mathrm{t}}\right)=\mathrm{N} \mathrm{l}_{\mathrm{t}}$, the total demand for bank loans $\left(e_{t}\right)=N e_{t}^{j}$, the total cumulative supply of newly-issued bonds or stocks $\left(\right.$ cap $\left.\cdot \mathrm{K}_{\mathrm{t}}\right)=\mathrm{N} \cdot \operatorname{cap} \cdot \mathrm{k}_{\mathrm{t}}$, and the total investment $\left(\mathrm{I}_{\mathrm{t}}\right)=\mathrm{N} \mathrm{I}_{\mathrm{t}}^{\mathrm{j}}$. The following equations summarize the equilibrium conditions for the corporate sector.

- Aggregate output ${ }^{22}: \quad \mathrm{Y}_{\mathrm{t}+1}=\mathrm{AK}_{\mathrm{t}}^{\alpha} \mathrm{L}_{\mathrm{t}}{ }^{1-\alpha}$

- Optimal capital stock:

$$
\mathrm{K}_{\mathrm{t}}= \begin{cases}\mathrm{K}_{\mathrm{t}}^{\mathrm{D}}=\overline{\mathrm{L}}\left(\frac{\alpha(\mathrm{A}+\mathrm{n})}{\mathrm{r}_{\mathrm{t}}+\xi+\mathrm{d}}\right)^{\frac{1}{1-\alpha}} & \text { if }\left(\frac{\varepsilon_{\mathrm{t}}}{\mathrm{P}_{\mathrm{t}}}\right) \mathrm{R}_{\mathrm{t}-1} \geq \beta \mathrm{F}_{\mathrm{t}} \\ \mathrm{K}_{\mathrm{t}}^{\mathrm{D}}-(1-\varphi)\left(\mathrm{F}_{\mathrm{t}}^{\mathrm{D}}-\left(\frac{\varepsilon_{\mathrm{t}}}{\mathrm{P}_{\mathrm{t}}}\right)\left(\frac{\mathrm{R}_{\mathrm{t}-1}}{\beta}\right)\right) & \text { if }\left(\frac{\varepsilon_{\mathrm{t}}}{\mathrm{P}_{\mathrm{t}}}\right) \mathrm{R}_{\mathrm{t}-1}<\beta \mathrm{F}_{\mathrm{t}}\end{cases}
$$

- Optimal investment: $I_{t}=\left(K_{t}-K_{t-1}\right)+d \cdot K_{t-1}$

- Firms' budget constraint: $\mathrm{K}_{\mathrm{t}}=\mathrm{e}_{\mathrm{t}}+\mathrm{cap} \cdot \mathrm{K}_{\mathrm{t}}^{\mathrm{D}}$ where $\mathrm{F}_{\mathrm{t}}= \begin{cases}\mathrm{F}_{\mathrm{t}}^{\mathrm{D}}=\left(1+\mathrm{r}_{\mathrm{t}-1}\right) \mathrm{F}_{\mathrm{t}-1}+\mathrm{X}_{\mathrm{t}} & \text { if }\left(\frac{\varepsilon_{\mathrm{t}}}{\mathrm{P}_{\mathrm{t}}}\right) \mathrm{R}_{\mathrm{t}-1} \geq \beta \mathrm{F}_{\mathrm{t}} \text { and not during the bailout period, } \\ \mathrm{F}_{\mathrm{t}}^{\mathrm{D}}-\varphi\left(\mathrm{F}_{\mathrm{t}}^{\mathrm{D}}-\frac{\varepsilon_{\mathrm{t}}}{\mathrm{P}_{\mathrm{t}}}\left(\frac{\mathrm{R}_{\mathrm{t}-1}}{\beta}\right)\right) & \text { if }\left(\frac{\varepsilon_{\mathrm{t}}}{\mathrm{P}_{\mathrm{t}}}\right) \mathrm{R}_{\mathrm{t}-1}<\beta \mathrm{F}_{\mathrm{t}}, \\ 0 & \text { from the start to the end of the bailout plan (bailout period) since there }\end{cases}$ will be a series of transfers of the remaining $F_{t}$ to the government to clean up the banking system,

$$
X_{t}=(1-v)\left(N P L_{t-1}\right) e_{t-1}\left(r_{t-1}+\xi\right),
$$

\footnotetext{
${ }^{22}$ In this setup, there is no uncertainty in aggregate output since $\mathrm{A}$ and $\alpha$ are constant and $\mathrm{K}_{\mathrm{t}}$ and $\mathrm{L}_{\mathrm{t}}$ are predetermined.
} 


$$
\mathrm{e}_{\mathrm{t}}= \begin{cases}\mathrm{e}_{\mathrm{t}}^{\mathrm{D}}=(1-\operatorname{cap}) \mathrm{K}_{\mathrm{t}}^{\mathrm{D}} & \text { if }\left(\frac{\varepsilon_{\mathrm{t}}}{\mathrm{P}_{\mathrm{t}}}\right) \mathrm{R}_{\mathrm{t}-1} \geq \beta \mathrm{F}_{\mathrm{t}}, \\ \mathrm{e}_{\mathrm{t}}^{\mathrm{D}}-(1-\varphi)\left(\mathrm{F}_{\mathrm{t}}^{\mathrm{D}}-\frac{\varepsilon_{\mathrm{t}}}{\mathrm{P}_{\mathrm{t}}}\left(\frac{\mathrm{R}_{\mathrm{t}-1}}{\beta}\right)\right) & \text { if }\left(\frac{\varepsilon_{\mathrm{t}}}{\mathrm{P}_{\mathrm{t}}}\right) \mathrm{R}_{\mathrm{t}-1}<\beta \mathrm{F}_{\mathrm{t}}\end{cases}
$$

\section{$\underline{\text { Banking Sector }}$}

In aggregate, the total supply of bank lending to the corporate sector $\left(\mathrm{e}_{t}\right)=\mathrm{M} \mathrm{e}_{\mathrm{t}}^{\mathrm{i}}$, the total demand for household deposits $\left(a_{t}\right)=M a_{t}^{i}$, the total demand for foreign borrowing $\left(b_{t}\right)=M b_{t}^{i}$, the total dividends paid by banks to the household sector $\left(X_{t}\right)=M X_{t}^{i}$, the cumulative NPL losses $\left(F_{t}\right)$ $=\mathrm{MF}_{\mathrm{t}}^{\mathrm{i}}$, the total $\mathrm{FX}$ profits or losses $\left(\mathrm{FX}_{\mathrm{t}}\right)=\mathrm{MFX} \mathrm{t}_{\mathrm{t}}^{\mathrm{i}}$, and the cumulative $\mathrm{FX}$ profits or losses $\left(\mathrm{AFX}_{\mathrm{t}}\right)$ $=\mathrm{MAFX}_{\mathrm{t}}^{\mathrm{i}}$. The following equations summarize the equilibrium conditions for the banking sector.

- Optimal real lending rate: $r_{t}^{1}=\left(\frac{1}{1-\mathrm{NPL}_{t}}\right)\left(r_{t}+\xi\right)$

- Optimal real deposit rate: $r_{t}=i_{t}^{b}=r_{t}^{c}=\psi_{0} i_{t}^{w}+\psi_{1}\left(b_{t}-\hat{b}\right)$

\section{- Banks' budget constraints:}

\section{Flow:}

Before the start of the bailout plan

$$
e_{t}-e_{t-1}=a_{t}-a_{t-1}+\frac{\varepsilon_{t}}{P_{t}} b_{t}-\frac{\varepsilon_{t-1}}{P_{t-1}} b_{t-1}-\left(A_{F X}-A_{t} X_{t-1}\right)-\left(F_{t}-F_{t-1}\right)
$$

Since the start of the bailout plan

$$
e_{t}-e_{t-1}=a_{t}-a_{t-1}+\frac{\varepsilon_{t}}{P_{t}} b_{t}-\frac{\varepsilon_{t-1}}{P_{t-1}} b_{t-1}-\left(A F X_{t}-A F X_{t-1}\right)-\left(F_{t}-F_{t-1}\right)-\left(G A_{t}-G A_{t-1}\right)
$$

\section{Stock:}

Before the start of the bailout plan

$$
e_{t}=\left(\frac{\varepsilon_{t}}{P_{t}}\right) b_{t}+a_{t}-A F X_{t}-F_{t}
$$


Since the start of the bailout plan

$e_{t}=\left(\frac{\varepsilon_{t}}{P_{t}}\right) b_{t}+a_{t}-A F X_{t}-F_{t}-G A_{t}$

(A7b_ii),

where $\mathrm{GA}_{\mathrm{t}}=\left(1+\mathrm{r}_{\mathrm{t}-1}\right) \mathrm{GA}_{\mathrm{t}-1}+$ transfer $_{\mathrm{t}}$,

$$
\begin{aligned}
& \text { transfer }_{t}= \begin{cases}0 & \text { if }\left(\frac{\varepsilon_{t}}{P_{t}}\right) R_{t-1} \geq \beta F_{t} \text { and not during the bailout period, } \\
\varphi\left(F_{t}^{D}-\frac{\varepsilon_{t}}{P_{t}}\left(\frac{R_{t-1}}{\beta}\right)\right) & \text { if }\left(\frac{\varepsilon_{t}}{P_{t}}\right) R_{t-1}<\beta F_{t} \\
F_{t}^{D} & \text { during the bailout period, }\end{cases} \\
& \text { FX }_{t}=\left(\frac{\varepsilon_{t}}{P_{t}}-\frac{\varepsilon_{t-1}}{P_{t-1}}\right)\left(1+r_{t-1}\right) b_{t-1} \\
& \operatorname{AFX~}_{t}=\left(1+r_{t-1}\right) A_{t-1}+F_{t}
\end{aligned}
$$

\section{$\underline{\text { Household Sector }}$}

The following equations summarize the equilibrium conditions for the household sector.

- Optimal consumption: $\mathrm{C}_{\mathrm{t}}=\left(\frac{1+\mathrm{r}_{\mathrm{t}-1}}{1+\delta}\right) \mathrm{C}_{\mathrm{t}-1}$

- Optimal real monetary aggregate: $\frac{\mathrm{M}_{\mathrm{t}}}{\mathrm{P}_{\mathrm{t}}}=\frac{\chi \mathrm{C}_{\mathrm{t}}\left(1+\mathrm{i}_{\mathrm{t}}\right)}{\mathrm{i}_{\mathrm{t}}}$ where $\left(1+i_{t}\right)=\left(1+\pi_{t}\right)\left(1+r_{t}\right)$ and $\left(\frac{P_{t+1}}{P_{t}}\right)=1+\pi_{t}$,

- Households' budget constraint:

$$
\begin{aligned}
a_{t}-a_{t-1}= & r_{t-1} a_{t-1}+(1-\eta)\left(Y_{t}+S_{t}-d \cdot K_{t-1}-r_{t-1} e_{t-1}+X_{t}\right) \\
& -C_{t}-\frac{M_{t}-M_{t-1}}{P_{t}}-\operatorname{cap} \cdot\left(K_{t}^{D}-K_{t-1}^{D}\right)
\end{aligned}
$$

where $\mathrm{S}_{\mathrm{t}}=\mathrm{nK}_{\mathrm{t}-1}^{\alpha} \mathrm{L}_{\mathrm{t}-1}{ }^{1-\alpha}$. 


\section{$\underline{\text { Public Sector }}$}

- Government's budget constraint:

$\underline{\text { Before the first sudden stop }}$

$$
\frac{\varepsilon_{t}}{P_{t}}\left(R_{t}-R_{t-1}\right)=\eta\left(Y_{t}+S_{t}-d \cdot K_{t-1}-r_{t-1} e_{t-1}+X_{t}\right)+\frac{M_{t}-M_{t-1}}{P_{t}}+r_{t-1} \frac{\varepsilon_{t}}{P_{t}} R_{t-1}-G_{t}-S_{t}
$$

During and after the first sudden stop

$$
\frac{\varepsilon_{t}}{P_{t}}\left(R_{t}-R_{t-1}\right)=\eta\left(Y_{t}+S_{t}-d \cdot K_{t-1}-r_{t-1} e_{t-1}+X_{t}\right)+\frac{M_{t}-M_{t-1}}{P_{t}}+r_{t-1} \frac{\varepsilon_{t}}{P_{t}} R_{t-1}-G_{t}-S_{t}+\left(L_{t}^{f}-\left(1+r_{t-1}\right) L_{t-1}^{f}\right)
$$

\section{National Account (combination of (A4), (A7a), (A10), (A11))}

Before the first sudden stop

$$
\mathrm{Y}_{\mathrm{t}}=\mathrm{I}_{\mathrm{t}}+\mathrm{C}_{\mathrm{t}}+\mathrm{G}_{\mathrm{t}}+\frac{\varepsilon_{\mathrm{t}}}{\mathrm{P}_{\mathrm{t}}}\left\langle\left(\mathrm{R}_{\mathrm{t}}-\mathrm{R}_{\mathrm{t}-1}\right)-\left(\mathrm{b}_{\mathrm{t}}-\mathrm{b}_{\mathrm{t}-1}\right)-\mathrm{r}_{\mathrm{t}-1} \mathrm{R}_{\mathrm{t}-1}+\mathrm{r}_{\mathrm{t}-1} \mathrm{~b}_{\mathrm{t}-1}\right\rangle
$$

During and after the first sudden stop

$$
\mathrm{Y}_{\mathrm{t}}=\mathrm{I}_{\mathrm{t}}+\mathrm{C}_{\mathrm{t}}+\mathrm{G}_{\mathrm{t}}+\frac{\varepsilon_{\mathrm{t}}}{\mathrm{P}_{\mathrm{t}}}\left\langle\left(\mathrm{R}_{\mathrm{t}}-\mathrm{R}_{\mathrm{t}-1}\right)-\left(\mathrm{b}_{\mathrm{t}}-\mathrm{b}_{\mathrm{t}-1}\right)-\mathrm{r}_{\mathrm{t}-1} \mathrm{R}_{\mathrm{t}-1}+\mathrm{r}_{\mathrm{t}-1} \mathrm{~b}_{\mathrm{t}-1}\right\rangle-\left(\mathrm{L}_{\mathrm{t}}^{\mathrm{f}}-\left(1+\mathrm{r}_{\mathrm{t}-1}\right) \mathrm{L}_{\mathrm{t}-1}^{\mathrm{f}}\right)
$$

\section{Modified Uncovered Interest Rate Parity}

$$
\left(\frac{\varepsilon_{t+1}}{\varepsilon_{t}}\right)=\frac{\left(1+i_{t}\right)}{\left(1+i_{t}^{w}\right)\left(1+\mathrm{P}_{\varepsilon}\right)} \rightarrow\left(\frac{\varepsilon_{t+1} / P_{t+1}}{\varepsilon_{t} / P_{t}}\right)=\frac{\left(1+\mathrm{r}_{t}\right)}{\left(1+i_{t}^{w}\right)\left(1+\mathrm{P}_{\varepsilon}\right)}
$$




\section{APPENDIX B}

\section{Parameters and Variables}

\begin{tabular}{|c|c|}
\hline \multirow[t]{16}{*}{ Parameters } & $\alpha=$ Income share of capital \\
\hline & $\mathrm{A}=$ Average production technology factor \\
\hline & $\begin{array}{l}\mathrm{n}=\text { Firms' additional revenue or cost factor due to government subsidies } \\
\text { or taxes }\end{array}$ \\
\hline & $\begin{array}{l}\text { cap }=\text { Fraction of firms' investment financed by capital markets } \\
(1 \text {-cap })=\text { Fraction of firms' investment financed by bank loans }\end{array}$ \\
\hline & $\mathrm{d}=$ Capital depreciation rate \\
\hline & $\Psi_{0}=$ Interest rate sensitivity to the world interest rate \\
\hline & $\begin{array}{l}\Psi_{1}=\text { Interest rate sensitivity to the aggregate level of banks' net foreign } \\
\text { borrowing }\end{array}$ \\
\hline & $\hat{b}=$ Perceived optimal level of aggregate banks' net foreign borrowing \\
\hline & $\xi=$ Operating expense factor \\
\hline & $v=$ Loan loss provisioning ratio \\
\hline & $\delta=$ Time preference factor \\
\hline & $\begin{array}{l}\chi=\text { Preference for money holdings relative to consumption } \\
\text { (a measure of households' degree of (liquidity) risk aversion) }\end{array}$ \\
\hline & $\eta=$ Personal income tax rate \\
\hline & $\begin{array}{l}\mathrm{P}_{\varepsilon}=\text { Expected exchange rate deviation from conventional uncovered } \\
\text { interest rate parity }\end{array}$ \\
\hline & $\begin{array}{l}\beta=\text { Fraction of banks' cumulative NPL losses which are expected by } \\
\text { foreign creditors to be covered by the country's international reserves }\end{array}$ \\
\hline & $\begin{array}{l}\varphi=\text { Fraction of banks' cash shortfalls subsidized by the government during } \\
\text { a sudden stop. } \\
(1-\varphi)=\text { Effect of a sudden stop on firms' investment }\end{array}$ \\
\hline
\end{tabular}




\begin{tabular}{|c|c|}
\hline \multirow{5}{*}{$\begin{array}{l}\text { Exogenous } \\
\text { Variables }\end{array}$} & $\mathrm{i}^{\mathrm{w}}=$ World nominal interest rate \\
\hline & $\pi=$ Inflation rate \\
\hline & $\mathrm{L}=$ Employed labor \\
\hline & $\begin{array}{l}\mathrm{NPL}=\text { Fraction of low-type firms }=\text { Banks' non-performing loans to total } \\
\text { loans ratio }\end{array}$ \\
\hline & $\mathrm{G}=$ Government spending \\
\hline \multirow{21}{*}{$\begin{array}{l}\text { Endogenous } \\
\text { Variables }\end{array}$} & $\mathrm{Y}=$ Output \\
\hline & $\mathrm{K}=$ Capital stock \\
\hline & $\mathrm{I}=$ Investment \\
\hline & $\mathrm{e}=$ Bank lending to the corporate sector \\
\hline & $\mathrm{b}=$ Banks' net foreign borrowing \\
\hline & $\mathrm{a}=$ Household deposits with banks \\
\hline & $\mathrm{C}=$ Consumption \\
\hline & $\mathrm{M} / \mathrm{P}=$ Real monetary aggregate \\
\hline & $\varepsilon / \mathrm{P}=$ Real exchange rate \\
\hline & $\mathrm{r}=$ Domestic real deposit rate \\
\hline & $r^{1}=$ Domestic real lending rate \\
\hline & $\mathrm{i}=$ Domestic nominal deposit rate \\
\hline & $\mathrm{S}=$ Government subsidies or taxes to the corporate sector \\
\hline & $\mathrm{X}=$ Dividends paid by banks to the household sector \\
\hline & $\mathrm{F}=$ Banks' cumulative NPL losses \\
\hline & $\mathrm{FX}=$ Banks' FX profits or losses \\
\hline & AFX $=$ Banks' cumulative FX profits or losses \\
\hline & $\mathrm{L}^{\mathrm{f}}=$ Government liabilities as a result of bank bailouts \\
\hline & $\mathrm{R}=$ International reserves \\
\hline & $\mathrm{GA}=$ Good assets \\
\hline & Transfer $=$ Transfer of banks' NPL losses to the government \\
\hline
\end{tabular}




\section{APPENDIX C}

\section{Steady State Solutions}

(C1) At a steady state, the loan loss provisioning ratio $\bar{v}$ must be $100 \%$ and hence, $\bar{X}=0, \overline{\mathrm{F}}=0$, $\overline{\mathrm{GA}}=0$, and $\overline{\mathrm{L}}=0$.

(C2) Assume that the steady state values for exogenous variables are the long-run averages.

$$
\begin{aligned}
& (\mathrm{C} 2.1) \overline{\mathrm{i}}^{\mathrm{w}}=\operatorname{average}\left(\mathrm{i}_{\mathrm{t}}^{\mathrm{w}}\right), \\
& (\mathrm{C} 2.2) \bar{\pi}=\operatorname{average}\left(\pi_{\mathrm{t}}\right), \\
& (\mathrm{C} 2.3) \overline{\mathrm{L}}=\operatorname{average}\left(\mathrm{L}_{\mathrm{t}}\right), \\
& (\mathrm{C} 2.4) \overline{\mathrm{NPL}}=\operatorname{average}\left(\mathrm{NPL}_{\mathrm{t}}\right), \\
& (\mathrm{C} 2.5) \overline{\mathrm{G}}=\operatorname{average}\left(\mathrm{G}_{\mathrm{t}}\right) .
\end{aligned}
$$

(C3) At a steady state, the exchange rate and the price level grow at the same rate $\bar{\pi}$.

$$
\frac{\varepsilon_{\mathrm{t}}}{\varepsilon_{\mathrm{t}-1}}=\frac{\mathrm{P}_{\mathrm{t}}}{\mathrm{P}_{\mathrm{t}-1}}=(1+\bar{\pi}) \rightarrow \frac{\varepsilon_{\mathrm{t}} / \varepsilon_{\mathrm{t}-1}}{\mathrm{P}_{\mathrm{t}} / \mathrm{P}_{\mathrm{t}-1}}=1
$$

(C4) Based on (C3), the real exchange rate $\left(\varepsilon_{t} / P_{t}\right)$ is constant at a steady state. Assume that $\bar{\varepsilon} / \overline{\mathrm{P}}=\operatorname{average}\left(\varepsilon_{\mathrm{t}} / \mathrm{P}_{\mathrm{t}}\right)$

$$
\frac{\varepsilon_{\mathrm{t}} / \mathrm{P}_{\mathrm{t}}}{\varepsilon_{\mathrm{t}-1} / \mathrm{P}_{\mathrm{t}-1}}=1 \rightarrow \varepsilon_{\mathrm{t}} / \mathrm{P}_{\mathrm{t}}=\varepsilon_{\mathrm{t}-1} / \mathrm{P}_{\mathrm{t}-1}=\bar{\varepsilon} / \overline{\mathrm{P}} \text {. Hence, } \overline{\mathrm{F}} \overline{\mathrm{X}}=0 \text { and } \overline{\mathrm{A} \overline{\mathrm{X}}}=0 \text {. }
$$

(C5) Based on (C4),

$$
\frac{\varepsilon_{\mathrm{t}} / \mathrm{P}_{\mathrm{t}}}{\varepsilon_{\mathrm{t}-1} / \mathrm{P}_{\mathrm{t}-1}}=1=\frac{\left(1+\mathrm{r}_{\mathrm{t}-1}\right)}{\left(1+\mathrm{i}_{\mathrm{t}-1}^{\mathrm{w}}\right)\left(1+\mathrm{P}_{\varepsilon}\right)} \rightarrow \overline{\mathrm{r}}=\left(1+\overline{\mathrm{i}}^{\mathrm{w}}\right)\left(1+\mathrm{P}_{\varepsilon}\right)-1
$$


(C6) $\overline{\mathrm{C}}=\left(\frac{1+\overline{\mathrm{r}}}{1+\delta}\right) \overline{\mathrm{C}} \quad \rightarrow \delta=\overline{\mathrm{r}}$.

(C7) $\overline{\mathrm{r}}=\psi_{0} \overline{\mathrm{i}}^{\mathrm{w}}+\psi_{1}(\overline{\mathrm{b}}-\hat{\mathrm{b}}) \quad \rightarrow \overline{\mathrm{b}}=\hat{\mathrm{b}}+\frac{\overline{\mathrm{r}}-\psi_{0} \overline{\mathrm{i}}^{\mathrm{w}}}{\psi_{1}}$.

(C8) $\quad \overline{\mathrm{r}}^{1}=\left(\frac{\overline{\mathrm{r}}+\xi}{1-\overline{\mathrm{NPL}}}\right)$.

(C9) $\overline{\mathrm{i}}=(1+\bar{\pi})(1+\overline{\mathrm{r}})-1$.

(C10) $\overline{\mathrm{K}}=\overline{\mathrm{L}}\left(\frac{\alpha(\mathrm{A}+\mathrm{n})}{\overline{\mathrm{r}}+\xi+\mathrm{d}}\right)^{\frac{1}{1-\alpha}}$.

(C11) $\overline{\mathrm{e}}=(1-\operatorname{cap}) \overline{\mathrm{K}}=(1-\operatorname{cap}) \overline{\mathrm{L}}\left(\frac{\alpha(\mathrm{A}+\mathrm{n})}{\overline{\mathrm{r}}+\xi+\mathrm{d}}\right)^{\frac{1}{1-\alpha}}$.

(C12) $\overline{\mathrm{Y}}=\mathrm{A} \overline{\mathrm{K}}^{\alpha} \overline{\mathrm{L}}^{1-\alpha}=\mathrm{A} \overline{\mathrm{L}}\left(\frac{\alpha(\mathrm{A}+\mathrm{n})}{\overline{\mathrm{r}}+\xi+\mathrm{d}}\right)^{\frac{\alpha}{1-\alpha}}$.

(C13) $\overline{\mathrm{S}}=\mathrm{n} \overline{\mathrm{K}}^{\alpha} \overline{\mathrm{L}}^{1-\alpha}=\mathrm{n} \overline{\mathrm{L}}\left(\frac{\alpha(\mathrm{A}+\mathrm{n})}{\overline{\mathrm{r}}+\xi+\mathrm{d}}\right)^{\frac{\alpha}{1-\alpha}}$.

(C14) $\frac{\overline{\mathrm{M}}}{\mathrm{P}}=\chi \overline{\mathrm{C}} \frac{(1+\overline{\mathrm{r}})(1+\bar{\pi})}{(1+\overline{\mathrm{r}})(1+\bar{\pi})-1}$.

$\begin{aligned}(\mathrm{C} 15) \quad \overline{\mathrm{b}}-\overline{\mathrm{b}} & =1 / \overline{\bar{\varepsilon}}\left[\begin{array}{l}(\overline{\mathrm{K}}-\overline{\mathrm{K}})-\eta \overline{\mathrm{r}}(1-\mathrm{cap}) \overline{\mathrm{K}} \\ -(1-\eta)(\overline{\mathrm{Y}}+\overline{\mathrm{S}})+\eta \overline{\mathrm{X}}+(1-\eta) \mathrm{d} \overline{\mathrm{K}}+\overline{\mathrm{C}} \\ +\left(\frac{\bar{\pi}}{1+\bar{\pi}}\right) \frac{\overline{\mathrm{M}}}{\overline{\mathrm{P}}}+\overline{\mathrm{r}} \frac{\bar{\varepsilon}}{\overline{\mathrm{P}}} \overline{\mathrm{b}}\end{array}\right] \\ & \rightarrow \overline{\mathrm{C}}=\left\langle\frac{(1-\eta)(\overline{\mathrm{Y}}+\overline{\mathrm{S}}-\mathrm{d} \overline{\mathrm{K}})+\eta(1-\mathrm{cap}) \overline{\mathrm{r}} \overline{\mathrm{K}}-\overline{\mathrm{r}}\left(\frac{\bar{\varepsilon}}{\overline{\mathrm{P}}}\right) \overline{\mathrm{b}}}{1+\left(\chi \frac{(1+\overline{\mathrm{r}}) \bar{\pi}}{(1+\overline{\mathrm{r}})(1+\bar{\pi})-1}\right)}\right\rangle .\end{aligned}$ 
$(\mathrm{C} 16) \overline{\mathrm{a}}-\overline{\mathrm{a}}=\overline{\mathrm{ra}}+(1-\eta)(\overline{\mathrm{Y}}+\overline{\mathrm{S}}-\mathrm{d} \cdot \overline{\mathrm{K}}-\overline{\mathrm{r}}(1-\operatorname{cap}) \overline{\mathrm{K}})-\overline{\mathrm{C}}-\left(\frac{\bar{\pi}}{1+\bar{\pi}}\right)\left(\frac{\overline{\mathrm{M}}}{\overline{\mathrm{P}}}\right)-\operatorname{cap}(\overline{\mathrm{K}}-\overline{\mathrm{K}})$

$\rightarrow \overline{\mathrm{a}}=\frac{\overline{\mathrm{C}}\left[1+\left(\chi \frac{(1+\overline{\mathrm{r}}) \bar{\pi}}{(1+\overline{\mathrm{r}})(1+\bar{\pi})-1}\right)\right]-(1-\eta)(\overline{\mathrm{Y}}+\overline{\mathrm{S}}-\mathrm{d} \cdot \overline{\mathrm{K}}-\overline{\mathrm{r}}(1-\text { cap }) \overline{\mathrm{K}})}{\overline{\mathrm{r}}}$

$\rightarrow \overline{\mathrm{a}}=(1-\operatorname{cap}) \overline{\mathrm{K}}-\left(\frac{\bar{\varepsilon}}{\overline{\mathrm{P}}}\right) \overline{\mathrm{b}}$.

(C17) $\frac{\bar{\varepsilon}}{\mathrm{P}}(\overline{\mathrm{R}}-\overline{\mathrm{R}})=\eta[\overline{\mathrm{Y}}+\overline{\mathrm{S}}-\mathrm{d} \cdot \overline{\mathrm{K}}-\overline{\mathrm{r}}(1-$ cap $) \overline{\mathrm{K}}]+\left(\frac{\bar{\pi}}{1+\bar{\pi}}\right)\left(\frac{\overline{\mathrm{M}}}{\overline{\mathrm{P}}}\right)+\overline{\mathrm{r}}\left(\frac{\bar{\varepsilon}}{\overline{\mathrm{P}}}\right) \overline{\mathrm{R}}-\overline{\mathrm{G}}-\overline{\mathrm{S}}$

$$
\begin{aligned}
& \left(\frac{\bar{\pi}}{1+\bar{\pi}}\right)\left(\chi \overline{\mathrm{C}} \frac{(1+\overline{\mathrm{r}})(1+\bar{\pi})}{(1+\overline{\mathrm{r}})(1+\bar{\pi})-1}\right)=\overline{\mathrm{G}}+\overline{\mathrm{S}}-\eta[\overline{\mathrm{Y}}+\overline{\mathrm{S}}-\mathrm{d} \cdot \overline{\mathrm{K}}-\overline{\mathrm{r}}(1-\operatorname{cap}) \overline{\mathrm{K}}]-\overline{\mathrm{r}}\left(\frac{\bar{\varepsilon}}{\overline{\mathrm{P}}}\right) \overline{\mathrm{R}} \\
& \rightarrow \overline{\mathrm{R}}=\frac{\overline{\mathrm{G}}+\overline{\mathrm{S}}-\eta[\overline{\mathrm{Y}}+\overline{\mathrm{S}}-\mathrm{d} \cdot \overline{\mathrm{K}}-\overline{\mathrm{r}}(1-\operatorname{cap}) \overline{\mathrm{K}}]-\left(\chi \overline{\mathrm{C}} \frac{(1+\overline{\mathrm{r}}) \bar{\pi}}{(1+\overline{\mathrm{r}})(1+\bar{\pi})-1}\right)}{\left(\frac{\bar{\varepsilon}}{\overline{\mathrm{P}}}\right) \overline{\mathrm{r}}} .
\end{aligned}
$$




\section{APPENDIX D}

\section{Linear Approximations and Solutions for Linearized Difference Equations}

\section{Linear approximations around the steady state values of $b$ and $C$}

\section{Change in $\mathrm{C}$ equation:}

$$
\mathrm{C}_{\mathrm{t}}-\mathrm{C}_{\mathrm{t}-1}=\left\{\frac{\psi \overline{\mathrm{C}}}{1+\delta}\right\}\left\langle\mathrm{b}_{\mathrm{t}-1}-\overline{\mathrm{b}}\right\rangle
$$

\section{Change in b equation:}

$$
\mathrm{b}_{\mathrm{t}}-\mathrm{b}_{\mathrm{t}-1}=\left\{\frac{\mathrm{A}^{\prime}}{1-\mathrm{C}^{\prime}}\right\}\left\langle\mathrm{C}_{\mathrm{t}-1}-\overline{\mathrm{C}}\right\rangle+\left\{\frac{1+\mathrm{B}^{\prime}}{1-\mathrm{C}^{\prime}}-1\right\}\left\langle\mathrm{b}_{\mathrm{t}-1}-\overline{\mathrm{b}}\right\rangle
$$

where

$$
\begin{aligned}
& \mathrm{A}^{\prime}=1 / \frac{\bar{\varepsilon}}{\overline{\mathrm{P}}}\left[1+\left(\frac{\chi(1+\delta) \bar{\pi}}{(1+\delta)(1+\bar{\pi})-1}\right)\right] \\
& \mathrm{B}^{\prime}=1 / \overline{\bar{\varepsilon}} \frac{\overline{\mathrm{K}} \cdot \psi_{1}}{\overline{\overline{\mathrm{P}}}}\left[\begin{array}{l}
\frac{(1-\eta) \cdot \alpha \cdot \psi_{1}}{(1-\alpha) \cdot(\delta+\xi+\mathrm{d})} \cdot(\overline{\mathrm{Y}}+\overline{\mathrm{S}})-\frac{(1-\eta) \cdot \mathrm{d} \cdot \overline{\mathrm{K}} \cdot \psi_{1}}{(1-\alpha) \cdot(\delta+\xi+\mathrm{d})} \\
+\frac{\overline{\mathrm{C}} \psi_{1}}{1+\delta}+\frac{\chi \overline{\mathrm{C}} \psi_{1} \bar{\pi}}{(1+\delta)(1+\bar{\pi})-1}+\frac{\chi \overline{\mathrm{C}} \psi_{1}(1+\delta)(1+\bar{\pi})}{[(1+\delta)(1+\bar{\pi})-1]^{2}} \\
+\psi_{1} \cdot \frac{\bar{\varepsilon}}{\overline{\mathrm{P}}} \cdot \overline{\mathrm{b}}+\frac{\delta \cdot \psi_{1}}{1+\delta} \cdot \frac{\bar{\varepsilon}}{\overline{\mathrm{P}}} \cdot \overline{\mathrm{b}}+\delta \cdot \frac{\bar{\varepsilon}}{\overline{\mathrm{P}}}
\end{array}\right], \\
& \mathrm{C}^{\prime}=1 / \frac{\bar{\varepsilon}}{\overline{\mathrm{P}}}\left[-\frac{\overline{\mathrm{K}} \cdot \psi_{1}}{(1-\alpha) \cdot(\delta+\xi+\mathrm{d})}+\frac{\chi \overline{\mathrm{C}} \psi_{1}(1+\bar{\pi})}{(1+\delta)(1+\bar{\pi})-1}-\frac{\chi \overline{\mathrm{C}} \psi_{1}(1+\delta)(1+\bar{\pi})^{2}}{[(1+\delta)(1+\bar{\pi})-1]^{2}}\right]
\end{aligned}
$$


Linearized difference equations (D1) and (D2) can be written in the matrix form as follows.

$$
\begin{aligned}
& \left(\begin{array}{l}
C_{t}-C_{t-1} \\
b_{t}-b_{t-1}
\end{array}\right)=\left(\begin{array}{ll}
0 & c \\
b & a
\end{array}\right)\left(\begin{array}{l}
C_{t-1}-\bar{C} \\
b_{t-1}-\bar{b}
\end{array}\right) \\
& \text { where } a=\left\{\frac{1+B^{\prime}}{1-C^{\prime}}-1\right\}, b=\left\{\frac{A^{\prime}}{1-C^{\prime}}\right\}, \text { and } c=\left\{\frac{\psi \bar{C}}{1+\delta}\right\} .
\end{aligned}
$$

Since $A^{\prime}>0,\left(1-C^{\prime}\right)>0$ and $\left(1+B^{\prime}\right)>\left(1-C^{\prime}\right), a, b$, and $c$ in equation (D3) are all positive. By setting equation (D1) (or $\mathrm{C}_{\mathrm{t}}-\mathrm{C}_{\mathrm{t}-1}$ ) and equation (D2) (or $\left.\mathrm{b}_{\mathrm{t}}-\mathrm{b}_{\mathrm{t}-1}\right)$ to zero, we have

$$
\begin{aligned}
& \operatorname{Locus} \Delta \mathbf{C}=\mathbf{0}: \quad b_{t-1}=\bar{b} \\
& \operatorname{Locus} \Delta \mathbf{b}=\mathbf{0}: \quad \frac{b_{t-1}-\bar{b}}{C_{t-1}-\bar{C}}=-\frac{b}{a}<0
\end{aligned}
$$

The phase diagram plotting the loci $\Delta \mathrm{C}=0$ and $\Delta \mathrm{b}=0$ can be depicted as follows.

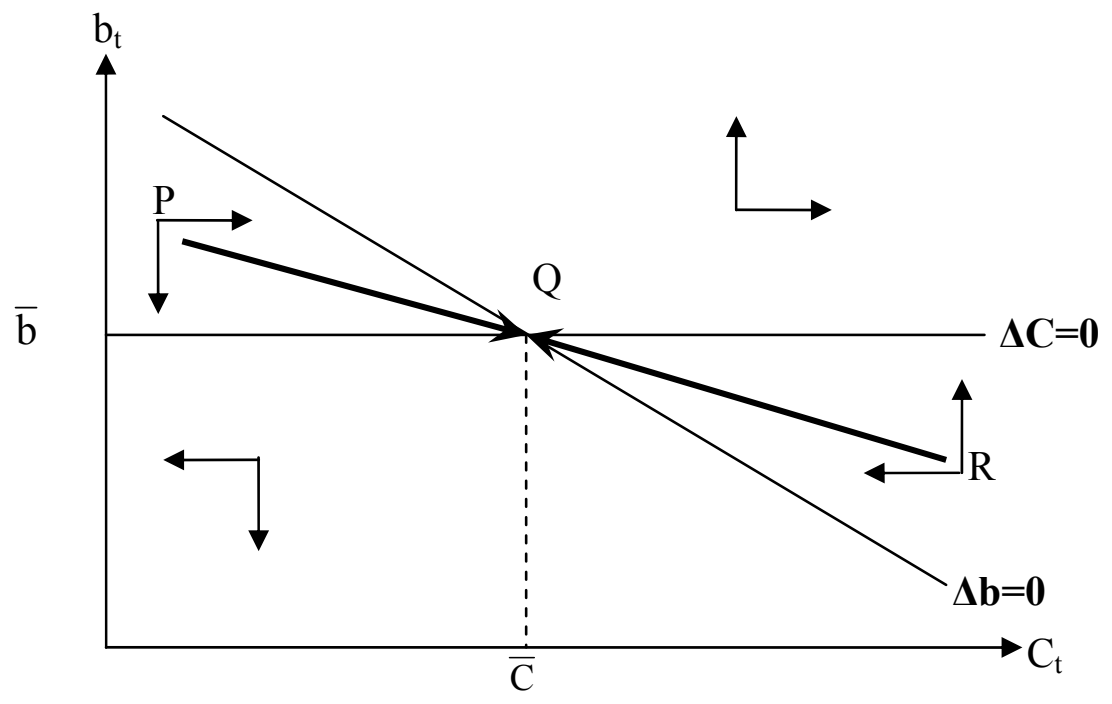

Q is an equilibrium point where all endogenous variables are at a steady state. There are both stable paths leading to the steady state (e.g., PQ and RQ) and unstable paths leading to an explosion. Hence, this equilibrium is a saddle point. 


\section{Solutions for linearized difference equations}

- Equation (D3) can be rewritten as

$$
\left(\begin{array}{l}
C_{t}-\bar{C} \\
b_{t}-\bar{b}
\end{array}\right)=\left(\begin{array}{cc}
1 & c \\
b & a+1
\end{array}\right)\left(\begin{array}{l}
C_{t-1}-\bar{C} \\
b_{t-1}-\bar{b}
\end{array}\right)
$$

- Let $\mathrm{X}_{t}=\left(\begin{array}{l}\mathrm{C}_{t}-\overline{\mathrm{C}} \\ \mathrm{b}_{\mathrm{t}}-\overline{\mathrm{b}}\end{array}\right)$ and $\mathrm{A}=\left(\begin{array}{cc}1 & \mathrm{c} \\ \mathrm{b} & \mathrm{a}+1\end{array}\right)$. Equation (D6) can be denoted as

$$
X_{t}=A \cdot X_{t-1}
$$

- If $\mathrm{A}$ has distinct eigenvalues, these exists a nonsingular matrix $\mathrm{E}$ such that $\mathrm{A}=\mathrm{E} \cdot \mathrm{W} \cdot \mathrm{E}^{-1}$ and hence

$$
\mathrm{X}_{\mathrm{t}}=\mathrm{E} \cdot \mathrm{W} \cdot \mathrm{E}^{-1} \mathrm{X}_{\mathrm{t}-1}
$$

$$
\begin{gathered}
\text { where } E=\text { eigenvector matrix with elements }\left(\begin{array}{cc}
\mathrm{e}_{1} & \mathrm{e}_{2} \\
1 & 1
\end{array}\right), \\
\mathrm{W}=\text { eigenvalue matrix with elements }\left(\begin{array}{cc}
\omega_{1} & 0 \\
0 & \omega_{2}
\end{array}\right),
\end{gathered}
$$

$$
\mathrm{E}^{-1}=\text { the inverse of eigenvector matrix with elements }\left(\begin{array}{cc}
g & h \\
i & j
\end{array}\right)=\left(\begin{array}{cc}
\frac{1}{e_{1}-e_{2}} & \frac{-e_{2}}{e_{1}-e_{2}} \\
\frac{-1}{e_{1}-e_{2}} & \frac{e_{1}}{e_{1}-e_{2}}
\end{array}\right) \text {. }
$$

- $\quad$ Since $\mathrm{X}_{\mathrm{t}-1}=\mathrm{E} \cdot \mathrm{W} \cdot \mathrm{E}^{-1} \mathrm{X}_{\mathrm{t}-2}$,

$$
\mathrm{X}_{\mathrm{t}}=\mathrm{E} \cdot \mathrm{W} \cdot \mathrm{E}^{-1}\left(\mathrm{E} \cdot \mathrm{W} \cdot \mathrm{E}^{-1} \mathrm{X}_{\mathrm{t}-2}\right)=\mathrm{E} \cdot \mathrm{W}^{2} \cdot \mathrm{E}^{-1} \mathrm{X}_{\mathrm{t}-2}=\mathrm{E} \cdot \mathrm{W}^{\mathrm{t}} \cdot \mathrm{E}^{-1} \mathrm{X}_{0}
$$

- General solutions for two linearized difference equations are

$$
\begin{aligned}
& \mathrm{C}_{\mathrm{t}}-\overline{\mathrm{C}}=\mathrm{e}_{1} \cdot \omega_{1}{ }^{\mathrm{t}} \cdot\left[\mathrm{g} \cdot\left(\mathrm{C}_{0}-\overline{\mathrm{C}}\right)+\mathrm{h} \cdot\left(\mathrm{b}_{0}-\overline{\mathrm{b}}\right)\right]+\mathrm{e}_{2} \cdot \omega_{2}{ }^{\mathrm{t}} \cdot\left[\mathrm{i} \cdot\left(\mathrm{C}_{0}-\overline{\mathrm{C}}\right)+\mathrm{j} \cdot\left(\mathrm{b}_{0}-\overline{\mathrm{b}}\right)\right] \\
& \mathrm{b}_{\mathrm{t}}-\overline{\mathrm{b}}=\omega_{1}{ }^{\mathrm{t}} \cdot\left[\mathrm{g} \cdot\left(\mathrm{C}_{0}-\overline{\mathrm{C}}\right)+\mathrm{h} \cdot\left(\mathrm{b}_{0}-\overline{\mathrm{b}}\right)\right]+\omega_{2}{ }^{\mathrm{t}} \cdot\left[\mathrm{i} \cdot\left(\mathrm{C}_{0}-\overline{\mathrm{C}}\right)+\mathrm{j} \cdot\left(\mathrm{b}_{0}-\overline{\mathrm{b}}\right)\right]
\end{aligned}
$$


- If both eigenvalues $\left(\omega_{1}, \omega_{2}\right)$ are less than 1 (greater than 1$)$, the equilibrium is stable (unstable). However, if one of the eigenvalues is greater than 1 while the other is less than 1 (say, $\omega_{1}>1$ and $\left.\omega_{2}<1\right)$, the equilibrium is a saddle point where it is stable in some directions, but unstable in others. When the equilibrium is a saddle point, unstable paths (the path with $\omega_{1}>1$ ) can be ruled out by setting an additional condition so that the term containing the unstable eigenvalue $\left[\mathrm{g} \cdot\left(\mathrm{C}_{0}-\overline{\mathrm{C}}\right)+\mathrm{h} \cdot\left(\mathrm{b}_{0}-\overline{\mathrm{b}}\right)\right.$ in equations (D10) and (D11)] is equal to zero, i.e.,

$$
\left(C_{0}-\bar{C}\right)=-h / g \cdot\left(b_{0}-\bar{b}\right)=e_{2} \cdot\left(b_{0}-\bar{b}\right)
$$

Hence, the solutions to difference equations, which lead to stable paths, are

$$
\begin{aligned}
& C_{0}-\bar{C}=e_{2}\left(b_{0}-\bar{b}\right) \\
& b_{t}-\bar{b}=\omega_{2}^{t}\left(b_{0}-\bar{b}\right)=\omega_{2}\left(b_{t-1}-\bar{b}\right) \\
& C_{t}-\bar{C}=e_{2} \cdot \omega_{2}^{t} \cdot\left(b_{0}-\bar{b}\right)=e_{2}\left(b_{t}-\bar{b}\right)
\end{aligned}
$$




\section{APPENDIX E}

Equilibrium Conditions in the Form of First Difference Equations

$$
\begin{aligned}
& Y_{t}-Y_{t-1}=A\left(K_{t-1}^{\alpha} L_{t-1}^{1-\alpha}-K_{t-2}^{\alpha} L_{t-2}^{1-\alpha}\right) \\
& I_{t}-I_{t-1}=\operatorname{Inv}_{0} \cdot\left[K_{t}^{M}-(1-d) K_{t-1}^{M}\right]+\left(\operatorname{Inv}_{1}-1\right) \cdot\left[I_{t-1}\right] \\
& r_{t}^{1}-r_{t-1}^{1}=\left(\frac{r_{t}+\xi}{1-N P L_{t}}\right)-\left(\frac{r_{t-1}+\xi}{1-N P L_{t-1}}\right) \\
& r_{t}-r_{t-1}=\psi_{0}\left(i_{t}^{w}-i_{t-1}^{w}\right)+\psi_{1}\left(b_{t}-b_{t-1}\right)
\end{aligned}
$$$$
b_{t}-b_{t-1}=\left(1 / \frac{\varepsilon_{t}}{P_{t}}\left[\begin{array}{l}
\left(\mathrm{I}_{t}-d \cdot K_{t-1}\right)-\eta r_{t-1}\left(K_{t-1}-c a p \cdot K_{t-1}^{D}\right) \\
-(1-\eta)\left(Y_{t}+S_{t}\right)+\eta X_{t}+(1-\eta) d K_{t-1}+C_{t} \\
+\frac{M_{t}-M_{t-1}+r_{t-1}}{P_{t}} b_{t-1}
\end{array}\right] \quad \text { if }\left(\frac{\varepsilon_{t}}{P_{t}}\right) R_{t-1} \geq \beta F_{t}\right.
$$$$
\frac{\frac{\varepsilon_{t}}{\mathrm{P}_{\mathrm{t}}}}{\mathrm{P}_{\mathrm{t}}}+\frac{\mathrm{M}_{\mathrm{t}}-\mathrm{M}_{\mathrm{t}-1}}{\mathrm{r}_{\mathrm{t}-1}} \frac{\varepsilon_{\mathrm{t}}}{\mathrm{P}_{\mathrm{t}}} \mathrm{b}_{\mathrm{t}-1}
$$

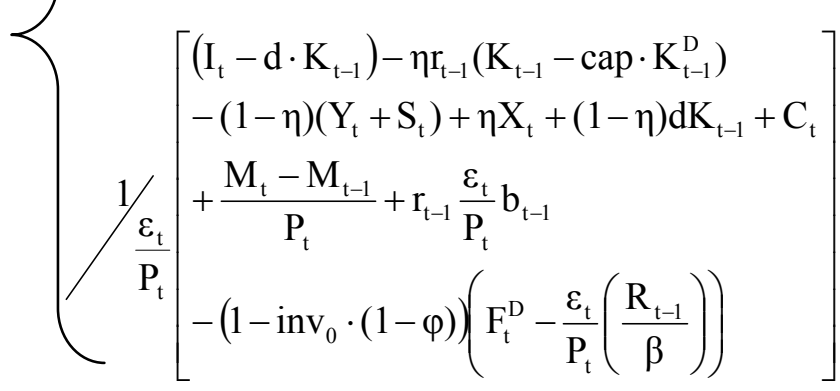$$
\mathrm{C}_{\mathrm{t}}-\mathrm{C}_{\mathrm{t}-1}=\left(\frac{1+\mathrm{r}_{\mathrm{t}-1}^{\mathrm{MA}}}{1+\delta}-1\right) \mathrm{C}_{\mathrm{t}-1}
$$$$
\text { if }\left(\frac{\varepsilon_{t}}{P_{t}}\right) R_{t-1}<\beta F_{t}
$$

$$
\begin{aligned}
& \frac{\mathrm{M}_{t}}{\mathrm{P}_{\mathrm{t}}}-\frac{\mathrm{M}_{\mathrm{t}-1}}{\mathrm{P}_{\mathrm{t}-1}}=\chi\left[\frac{\mathrm{C}_{\mathrm{t}}\left(1+\mathrm{i}_{\mathrm{t}}^{\mathrm{MA}}\right)}{\mathrm{i}_{\mathrm{t}}^{\mathrm{MA}}}-\frac{\mathrm{C}_{\mathrm{t}-1}\left(1+\mathrm{i}_{\mathrm{t}-1}^{\mathrm{MA}}\right)}{\mathrm{i}_{\mathrm{t}-1}^{\mathrm{MA}}}\right] \\
& \frac{\varepsilon_{t}}{\mathrm{P}_{\mathrm{t}}}-\frac{\varepsilon_{\mathrm{t}-1}}{\mathrm{P}_{\mathrm{t}-1}}=\left(\frac{1+\mathrm{r}_{\mathrm{t}-1}}{\left(1+\mathrm{i}_{\mathrm{t}-1}^{\mathrm{w}}\right)\left(1+\mathrm{P}_{\varepsilon}\right)}-1\right)\left(\frac{\varepsilon_{\mathrm{t}-1}}{\mathrm{P}_{\mathrm{t}-1}}\right)
\end{aligned}
$$




$$
\begin{aligned}
& \text { where } \mathrm{K}_{\mathrm{t}}^{\mathrm{M}}=\left\{\mathrm{K}_{\mathrm{t}}^{\mathrm{MD}}=\overline{\mathrm{L}}\left(\frac{\alpha(\mathrm{A}+\mathrm{n})}{\mathrm{r}_{\mathrm{t}}^{\mathrm{MA}}+\xi+\mathrm{d}}\right)^{\frac{1}{1-\alpha}} \quad \text { if }\left(\frac{\varepsilon_{\mathrm{t}}}{\mathrm{P}_{\mathrm{t}}}\right) \mathrm{R}_{\mathrm{t}-1} \geq \beta \mathrm{F}_{\mathrm{t}}\right. \text {, } \\
& \left\{\mathrm{K}_{\mathrm{t}}^{\mathrm{MD}}-(1-\varphi)\left(\mathrm{F}_{\mathrm{t}}^{\mathrm{D}}-\left(\frac{\varepsilon_{\mathrm{t}}}{\mathrm{P}_{\mathrm{t}}}\right)\left(\frac{\mathrm{R}_{\mathrm{t}-1}}{\beta}\right)\right) \quad \text { if }\left(\frac{\varepsilon_{\mathrm{t}}}{\mathrm{P}_{\mathrm{t}}}\right) \mathrm{R}_{\mathrm{t}-1}<\beta \mathrm{F}_{\mathrm{t}},\right. \\
& \mathrm{K}_{\mathrm{t}}=(1-\mathrm{d}) \mathrm{K}_{\mathrm{t}-1}+\mathrm{I}_{\mathrm{t}} \text {, } \\
& \mathrm{K}_{\mathrm{t}}^{\mathrm{D}}=\mathrm{K}_{\mathrm{t}} \\
& \left\{\mathrm{K}_{\mathrm{t}}+\operatorname{inv}_{0}(1-\varphi)\left(\mathrm{F}_{\mathrm{t}}^{\mathrm{D}}-\left(\frac{\varepsilon_{\mathrm{t}}}{\mathrm{P}_{\mathrm{t}}}\right)\left(\frac{\mathrm{R}_{\mathrm{t}-1}}{\beta}\right)\right)\right. \\
& \text { if }\left(\frac{\varepsilon_{t}}{P_{t}}\right) R_{t-1} \geq \beta F_{t} \text {, } \\
& \text { if }\left(\frac{\varepsilon_{t}}{P_{t}}\right) R_{t-1}<\beta F_{t} \\
& \left(1+i_{t}\right)=\left(1+\pi_{t}\right)\left(1+r_{t}\right) \\
& \mathrm{X}_{\mathrm{t}}=(1-v)\left(\mathrm{NPL}_{\mathrm{t}-1}\right)\left(\mathrm{K}_{\mathrm{t}-1}-\mathrm{cap} \cdot \mathrm{K}_{\mathrm{t}-1}^{\mathrm{D}}\right)\left(\mathrm{r}_{\mathrm{t}-1}+\xi\right) \text {, } \\
& F_{t}^{D}=\left(1+r_{t-1}\right) F_{t-1}+X_{t} \text {, } \\
& \mathrm{F}_{\mathrm{t}}=\int \mathrm{F}_{\mathrm{t}}^{\mathrm{D}} \quad \text { if }\left(\frac{\varepsilon_{\mathrm{t}}}{\mathrm{P}_{\mathrm{t}}}\right) \mathrm{R}_{\mathrm{t}-1} \geq \beta \mathrm{F}_{t} \text { and not during the bailout period, } \\
& \left\{\mathrm{F}_{\mathrm{t}}^{\mathrm{D}}-\left(1-\operatorname{inv}_{0}(1-\varphi)\right)\left(\mathrm{F}_{\mathrm{t}}^{\mathrm{D}}-\frac{\varepsilon_{\mathrm{t}}}{\mathrm{P}_{\mathrm{t}}}\left(\frac{\mathrm{R}_{\mathrm{t}-1}}{\beta}\right)\right) \quad \text { if }\left(\frac{\varepsilon_{\mathrm{t}}}{\mathrm{P}_{\mathrm{t}}}\right) \mathrm{R}_{\mathrm{t}-1}<\beta \mathrm{F}_{t},\right. \\
& \mathrm{S}_{\mathrm{t}}=\mathrm{nK}_{\mathrm{t}-1}^{\alpha} \mathrm{L}_{\mathrm{t}-1}{ }^{1-\alpha} \text {. }
\end{aligned}
$$




\section{APPENDIX F}

\section{Descriptions and Data Sources of Variables Used as Instruments}

\begin{tabular}{|c|c|c|}
\hline Variable & Description & Source \\
\hline $\begin{array}{l}\text { Change in the world } \\
\text { interest rate }\end{array}$ & $\begin{array}{l}\text { Change in the 3-month US certificate } \\
\text { of deposit (secondary market) interest } \\
\text { rate }\end{array}$ & $\begin{array}{l}\text { Monthly 3-month US } \\
\text { certificate of deposit } \\
\text { (secondary market) interest } \\
\text { rate from the IMF-IFS }\end{array}$ \\
\hline $\begin{array}{l}\text { Change in the world } \\
\text { inflation rate }\end{array}$ & $\begin{array}{l}\text { Change in the US inflation rate } \\
\text { (US inflation rate = Change in US } \\
\text { consumer price index (CPI) from the } \\
\text { same month of the previous year) }\end{array}$ & $\begin{array}{l}\text { Monthly change in US CPI } \\
\text { from Datastream }\end{array}$ \\
\hline $\begin{array}{l}\text { Percentage change in } \\
\text { the world industrial } \\
\text { production index }\end{array}$ & $\begin{array}{l}\text { Percentage change in the US } \\
\text { industrial production index }\end{array}$ & $\begin{array}{l}\text { Monthly seasonally-adjusted } \\
\text { US industrial production } \\
\text { index }(2000=1000) \text { from } \\
\text { Datastream }\end{array}$ \\
\hline $\begin{array}{l}\text { Log return on the spot } \\
\text { JPY/USD exchange rate }\end{array}$ & $\begin{array}{l}\text { Change in the natural log of the spot } \\
\text { JPY/USD exchange rate }\end{array}$ & $\begin{array}{l}\text { Monthly spot JPY/USD } \\
\text { exchange rate from } \\
\text { Datastream }\end{array}$ \\
\hline
\end{tabular}




\section{APPENDIX G}

\section{Steps to Calculate Partial-Sample GMM Estimators and Wald Statistics}

Step 1: Estimate parameter values for each sub-period (pre-crisis, crisis, and post-crisis periods) simultaneously using two-step GMM

Step 1.1: Form 3 sets of moment conditions for 3 sub-periods, i.e., $m\left(W_{t}, \beta_{1}, \delta\right), m\left(W_{t}, \beta_{2}, \delta\right)$, and $m\left(W_{t}, \beta_{3}, \delta\right)$, and arrange them in the following way.

$$
\begin{aligned}
& \overline{\mathrm{m}}_{\mathrm{T}}\left(\theta, \pi_{1}, \pi_{2}\right)=\frac{1}{\mathrm{~T}} \sum_{1}^{\mathrm{T} \pi_{1}}\left(\begin{array}{c}
\mathrm{m}\left(\mathrm{W}_{\mathrm{t}}, \beta_{1}, \delta\right) \\
0 \\
0
\end{array}\right)+\frac{1}{\mathrm{~T}} \sum_{\mathrm{T} \pi_{1}+1}^{\mathrm{T} \pi_{2}}\left(\begin{array}{c}
0 \\
\mathrm{~m}\left(\mathrm{~W}_{\mathrm{t}}, \beta_{2}, \delta\right) \\
0
\end{array}\right)+\frac{1}{\mathrm{~T}} \sum_{\mathrm{T} \pi_{2}+1}^{\mathrm{T}}\left(\begin{array}{c}
0 \\
0 \\
\mathrm{~m}\left(\mathrm{~W}_{\mathrm{t}}, \beta_{3}, \delta\right)
\end{array}\right) \in \mathrm{R}^{3 \mathrm{v}}, \\
& \text { where } \mathrm{T} \pi_{1} \text { is the first breakpoint, } \\
& \mathrm{T} \pi_{2} \text { is the second breakpoint }\left(0 \leq \pi_{1} \leq \pi_{2} \leq 1\right), \\
& \theta=\left(\beta_{1}, \beta_{2}, \beta_{3}, \delta\right) \in \mathrm{B} \times \mathrm{B} \times \mathrm{B} \times \Delta \subset \mathrm{R}^{\mathrm{p}} \times \mathrm{R}^{\mathrm{p}} \times \mathrm{R}^{\mathrm{p}} \times \mathrm{R}^{\mathrm{q}}, \\
& \beta=\text { Parameters of interest, which are assumed to be different across sub-periods } \\
& \quad\left(\mathrm{i} . \mathrm{e} ., \beta_{1} \text { for pre-crisis period, } \beta_{2} \text { for crisis period, and } \beta_{3} \text { for post-crisis period }\right), \\
& \delta=\text { Other parameters, which are assumed be constant throughout the whole sample } \\
& \quad \text { period, } \\
& \mathrm{m}(\cdot, \cdot, \cdot) \text { is a function from } \mathrm{W} \times \mathrm{B} \times \Delta \text { to } \mathrm{R}^{v}, \\
& \mathrm{~W} \text { are observed sample and } \mathrm{W} \subset \mathrm{R}{ }^{\mathrm{k}} .
\end{aligned}
$$

\section{Step 1.2: First stage GMM}

1.2.1 Use a sub-optimal weighting matrix $\left(I \otimes Z^{\prime} Z\right)^{-1}$ where $Z$ is the vector of instruments (This is equivalent to applying non-linear two-stage least squares) to estimate the initial values of parameters $\left(\beta_{1}, \beta_{2}, \beta_{3}, \delta\right)\left[\right.$ denoted by $\left.\left(\widetilde{\beta}_{1}, \widetilde{\beta}_{2}, \widetilde{\beta}_{3}, \widetilde{\delta}\right)\right]$. 
1.2.2 Use the estimated initial values of those parameters from step 1.2.1 $\left(\widetilde{\beta}_{1}, \widetilde{\beta}_{2}, \widetilde{\beta}_{3}, \widetilde{\delta}\right)$ to calculate the optimal weighting matrix $\hat{\gamma}\left(\pi_{1}, \pi_{2}\right)$ for the second stage GMM. The estimation of the optimal weighting matrix involves the following additional steps.

1.2.2.1 Calculate heteroskedasticity and autocorrelation consistent (HAC) covariance matrix estimators for each sub-period.

$$
\begin{aligned}
& \hat{\mathrm{S}}_{1}\left(\pi_{1}, \pi_{2}\right)=\sum_{v=0}^{\mathrm{T} \pi_{1}-1} \mathrm{k}\left(v / 1\left(\mathrm{~T} \pi_{1}\right)\right) \times \frac{1}{\mathrm{~T} \pi_{1}} \sum_{v+1}^{\mathrm{T} \pi_{1}}\left(\mathrm{~m}\left(\mathrm{~W}_{\mathrm{t}}, \widetilde{\beta}_{1}, \widetilde{\delta}\right)\right)\left(\mathrm{m}\left(\mathrm{W}_{\mathrm{t}-\mathrm{v}}, \tilde{\beta}_{1}, \widetilde{\delta}\right)\right)^{\prime} \\
& +\sum_{v=1}^{\mathrm{T} \pi_{1}-1} \mathrm{k}\left(v / 1\left(\mathrm{~T} \pi_{1}\right)\right) \times \frac{1}{\mathrm{~T} \pi_{1}} \sum_{v+1}^{\mathrm{T} \pi_{1}}\left(\mathrm{~m}\left(\mathrm{~W}_{\mathrm{t}-\mathrm{v}}, \tilde{\beta}_{1}, \widetilde{\delta}\right)\right)\left(\mathrm{m}\left(\mathrm{W}_{\mathrm{t}}, \tilde{\beta}_{1}, \widetilde{\delta}\right)\right)^{\prime}, \\
& \hat{\mathrm{S}}_{2}\left(\pi_{1}, \pi_{2}\right)=\sum_{v=0}^{\mathrm{T} \pi_{2}-\mathrm{T} \pi_{1}-1} \mathrm{k}\left(v / 1\left(\mathrm{~T} \pi_{2}-\mathrm{T} \pi_{1}\right)\right) \times \frac{1}{\mathrm{~T} \pi_{2}-\mathrm{T} \pi_{1}} \sum_{v+1+\mathrm{T} \pi_{1}}^{\mathrm{T} \pi_{2}}\left(\mathrm{~m}\left(\mathrm{~W}_{\mathrm{t}}, \widetilde{\beta}_{2}, \widetilde{\delta}\right)\right)\left(\mathrm{m}\left(\mathrm{W}_{\mathrm{t}-\mathrm{v}}, \widetilde{\beta}_{2}, \widetilde{\delta}\right)\right)^{\prime} \\
& +\sum_{v=1}^{\mathrm{T} \pi_{2}-\mathrm{T} \pi_{1}-1} \mathrm{k}\left(\mathrm{v} / 1\left(\mathrm{~T} \pi_{2}-\mathrm{T} \pi_{1}\right)\right) \times \frac{1}{\mathrm{~T} \pi_{2}-\mathrm{T} \pi_{1}} \sum_{v+1+\mathrm{T} \pi_{1}}^{\mathrm{T} \pi_{2}}\left(\mathrm{~m}\left(\mathrm{~W}_{\mathrm{t}-\mathrm{v}}, \widetilde{\beta}_{2}, \widetilde{\delta}\right)\right)\left(\mathrm{m}\left(\mathrm{W}_{\mathrm{t}}, \widetilde{\beta}_{2}, \widetilde{\delta}\right)\right)^{\prime}, \\
& \hat{\mathrm{S}}_{3}\left(\pi_{1}, \pi_{2}\right)=\sum_{v=0}^{\mathrm{T}-\mathrm{T} \pi_{2}-1} \mathrm{k}\left(v / 1\left(\mathrm{~T}-\mathrm{T} \pi_{2}\right)\right) \times \frac{1}{\mathrm{~T}-\mathrm{T} \pi_{2}} \sum_{v+1+\mathrm{T} \pi_{2}}^{\mathrm{T}}\left(\mathrm{m}\left(\mathrm{W}_{\mathrm{t}}, \widetilde{\beta}_{3}, \widetilde{\delta}\right)\right)\left(\mathrm{m}\left(\mathrm{W}_{\mathrm{t}-\mathrm{v}}, \widetilde{\beta}_{3}, \widetilde{\delta}\right)\right)^{\prime} \\
& +\sum_{v=1}^{\mathrm{T}-\mathrm{T} \pi_{2}-1} \mathrm{k}\left(v / 1\left(\mathrm{~T}-\mathrm{T} \pi_{2}\right)\right) \times \frac{1}{\mathrm{~T}-\mathrm{T} \pi_{2}} \sum_{v+1+\mathrm{T} \pi_{2}}^{\mathrm{T}}\left(\mathrm{m}\left(\mathrm{W}_{\mathrm{t}-\mathrm{v}}, \tilde{\beta}_{3}, \widetilde{\delta}\right)\right)\left(\mathrm{m}\left(\mathrm{W}_{\mathrm{t}}, \tilde{\beta}_{3}, \tilde{\delta}\right)\right)^{\prime},
\end{aligned}
$$

where $\mathrm{k}()=.\mathrm{kernel}^{23}$

$1(n)=$ bandwidth parameter,

$\mathrm{n}=$ number of observations.

1.2.2.2 Multiply each $\hat{\mathrm{S}}\left(\pi_{1}, \pi_{2}\right)$ by the proportion of sample for each sub-period and arrange them in block diagonal form to be used as the optimal weighting matrix in step 1.3 as follows.

$$
\hat{\gamma}\left(\pi_{1}, \pi_{2}\right)=\operatorname{Diag}\left\{\frac{\hat{S}_{1}^{-1}\left(\pi_{1}, \pi_{2}\right)}{\pi_{1}}, \frac{\hat{S}_{2}^{-1}\left(\pi_{1}, \pi_{2}\right)}{\pi_{2}-\pi_{1}}, \frac{\hat{S}_{2}^{-1}\left(\pi_{1}, \pi_{2}\right)}{1-\pi_{2}-\pi_{1}}\right\}
$$

\footnotetext{
${ }^{23}$ There are several choices of kernel functions, e.g., Bartlett, Parzen, and Quadratic Spectral. Newey-West (Bartlett) kernel is used in this estimation.
} 


\section{Step 1.3: Second stage GMM}

Minimize the following objective function using the moment conditions from step 1.1 and the optimal weighting matrix from step 1.2.2.2 to obtain the partial sample GMM estimators of $\left(\beta_{1}, \beta_{2}, \beta_{3}, \delta\right)$

[denoted by $\left.\hat{\theta}=\left(\hat{\beta}_{1}, \hat{\beta}_{2}, \hat{\beta}_{3}, \hat{\delta}\right)\right]$.

$$
\left.\overline{\mathrm{m}}_{\mathrm{T}}\left(\hat{\theta}\left(\pi_{1}, \pi_{2}\right), \pi_{1}, \pi_{2}\right)^{\prime} \hat{\gamma}\left(\pi_{1}, \pi_{2}\right) \hat{\theta}\left(\pi_{1}, \pi_{2}\right), \pi_{1}, \pi_{2}\right)=\inf _{\theta \in \Theta} \overline{\mathrm{m}}_{\mathrm{T}}\left(\theta, \pi_{1}, \pi_{2}\right)^{\prime} \hat{\gamma}\left(\pi_{1}, \pi_{2}\right) \overline{\mathrm{m}}_{\mathrm{T}}\left(\theta, \pi_{1}, \pi_{2}\right) .
$$

\section{Step 2: Calculate Wald statistics}

$$
\mathrm{W}_{\mathrm{T}}\left(\pi_{1}, \pi_{2}\right)=\hat{\theta}\left(\pi_{1}, \pi_{2}\right)^{\prime} \mathrm{H}^{\prime}\left(\mathrm{H} \hat{\Omega}\left(\pi_{1}, \pi_{2}\right) \mathrm{H}^{\prime}\right)^{-1} \mathrm{H} \hat{\theta}\left(\pi_{1}, \pi_{2}\right),
$$

where $\hat{\theta}\left(\pi_{1}, \pi_{2}\right)=$ Parameter vector,

$$
\begin{aligned}
& \hat{\Omega}\left(\pi_{1}, \pi_{2}\right)=\text { Estimated covariance matrix of parameter vector } \hat{\theta}\left(\pi_{1}, \pi_{2}\right), \\
& H=\left\{\begin{array}{l}
\left\lfloor I_{p}: 0:-I_{p}: 0\right\rfloor \text { for } H_{O}: \hat{\beta}_{1}=\hat{\beta}_{3}, \\
\left\lfloor I_{p}:-I_{p}: 0: 0\right\rfloor \text { for } H_{O}: \hat{\beta}_{1}=\hat{\beta}_{2}, \\
\left.\mid 0: I_{p}:-I_{p}: 0\right\rfloor \text { for } H_{O}: \hat{\beta}_{2}=\hat{\beta}_{3} .
\end{array}\right.
\end{aligned}
$$

\section{Step 3: Critical values}

In the case where breakpoints $\left(\pi_{1}\right.$ and $\left.\pi_{2}\right)$ are known, $\mathrm{W}_{\mathrm{T}}\left(\pi_{1}, \pi_{2}\right)$ has a chi-square distribution with $\mathrm{p}$ degrees of freedom under the null hypothesis, where $\mathrm{p}$ is the number of restrictions. 
Figure 1: Time-Series Patterns of Variables

This figure shows monthly time-series of macroeconomic, financial market, and bank variables of Thailand as well as the world interest rate from January 1993 to June 2007. Panels A to C plot the annualized real traded output, the real net capital stock of the private sector, and the annualized real private investment in traded sectors. Panels D to F plot the annualized real private consumption, the real monetary aggregate, and the banks' net foreign borrowing. Panels G to I show monthly time-series of the real exchange rate, the annualized domestic nominal deposit rate, and the annualized domestic real deposit rate. Panels J to L plot the annualized domestic real lending rate, the employed labor, and the banks' non-performing loans to total loans ratio. Panels M, N and P plot the international reserves net of the Bank of Thailand's forward position, the annualized world nominal interest rate, and the annualized domestic inflation rate, respectively. The details about how these variables are obtained or computed are described in table 1.

Million Baht

A. Real Output (Annualized Y)

$\vec{\omega}$

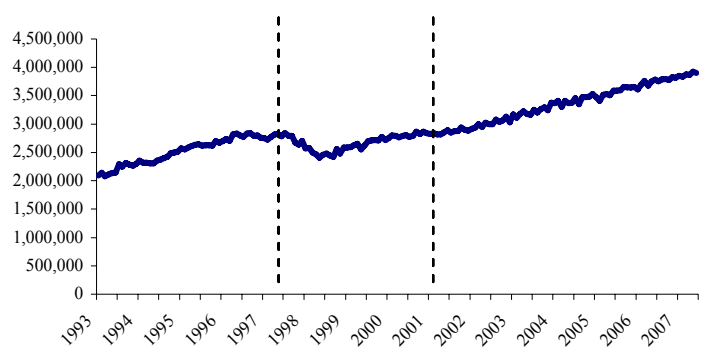

Million Baht

D. Real Consumption (Annualized C)

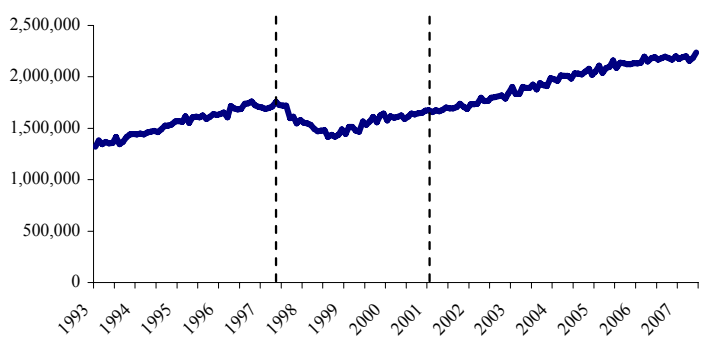

Million Baht

B. Real Net Capital Stock of Private Sector (K)

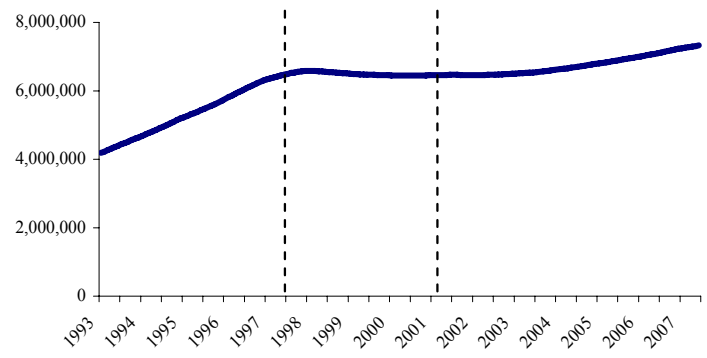

Million Baht

E. Real Monetary Aggregate (M/P)

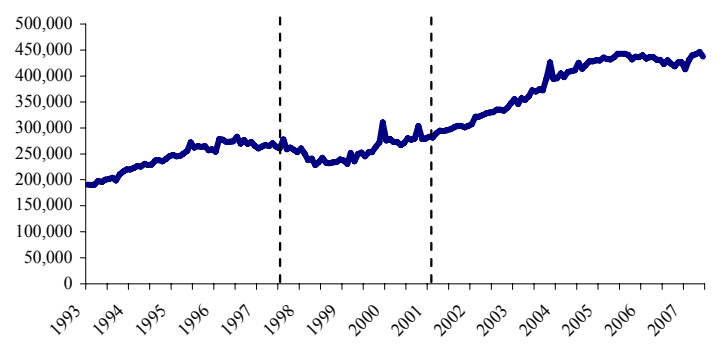

Million Baht

C. Real Investment (Annualized I)

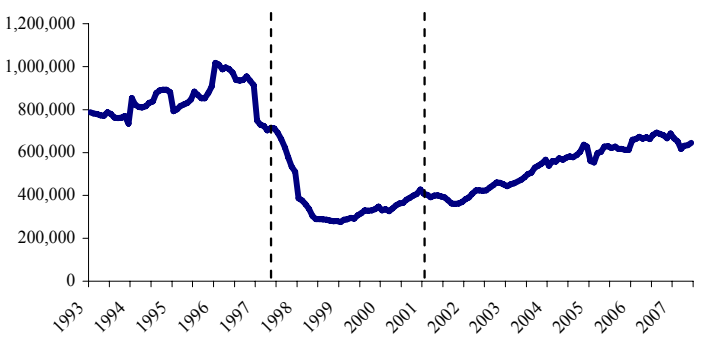

Million USD

F. Banks' Net Foreign Borrowing (b)

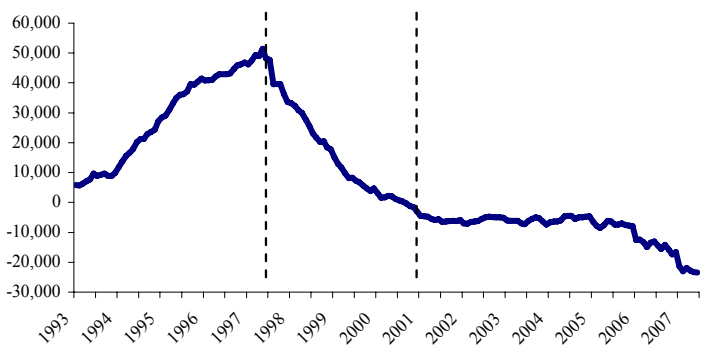


G. Real Exchange Rate $(\varepsilon / P)$

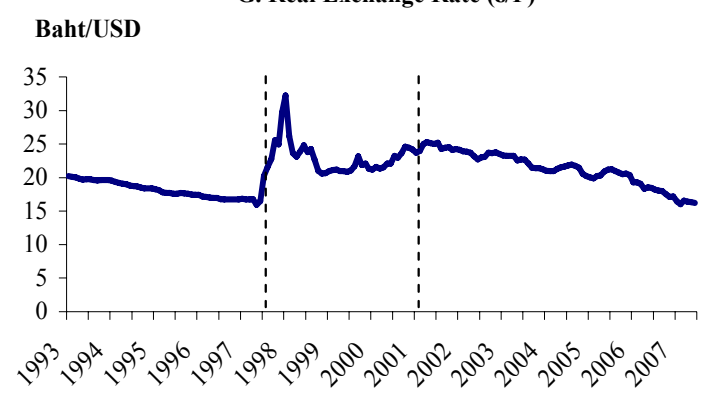

$\% \quad$ J. Real Lending Rate (Annualized r')

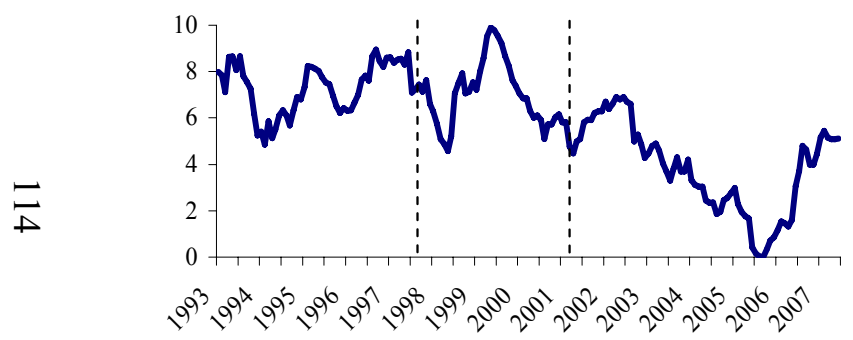

H. Nominal Deposit Rate (Annualized i)
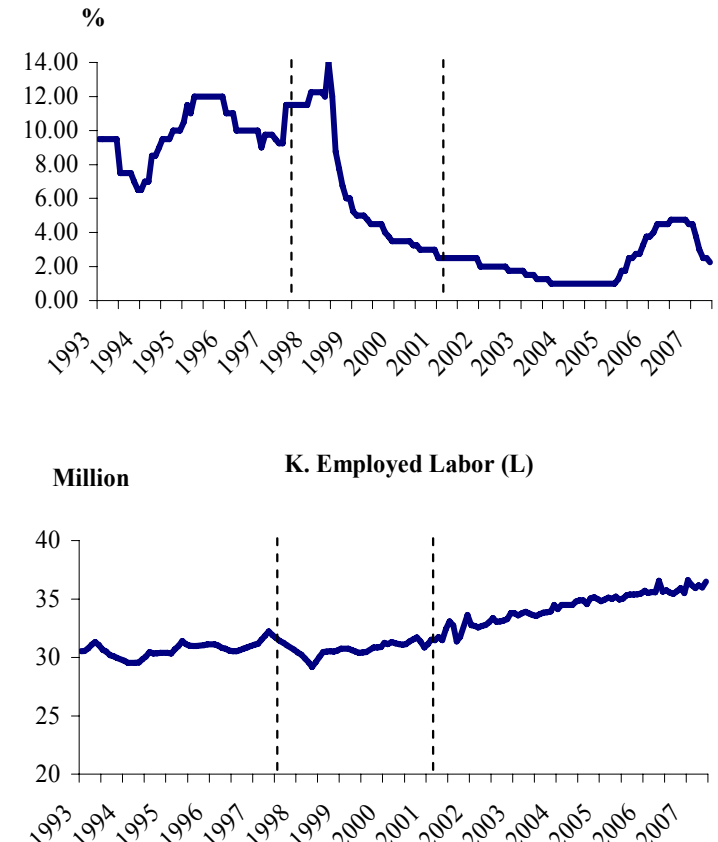

I. Real Deposit Rate (Annualized r)

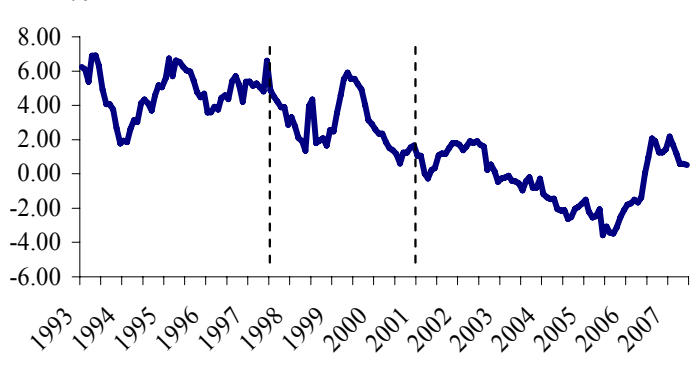

L. Non-Performing Loans to Total Loans (NPL)

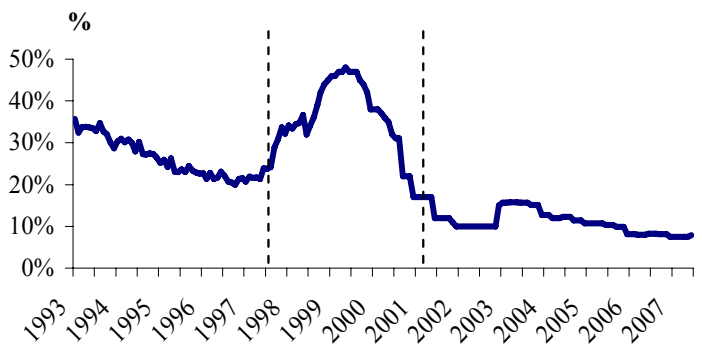

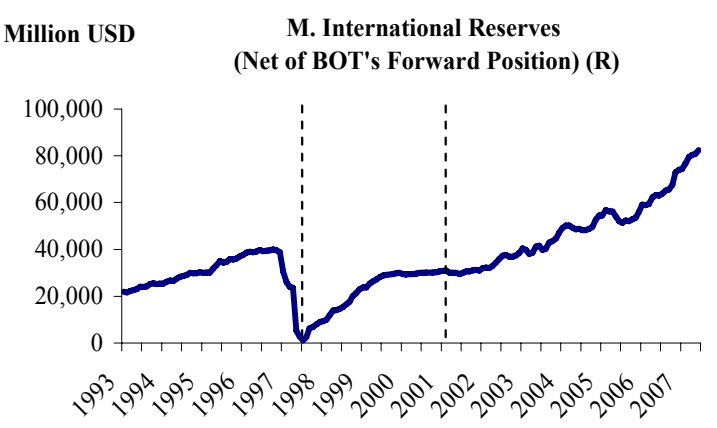

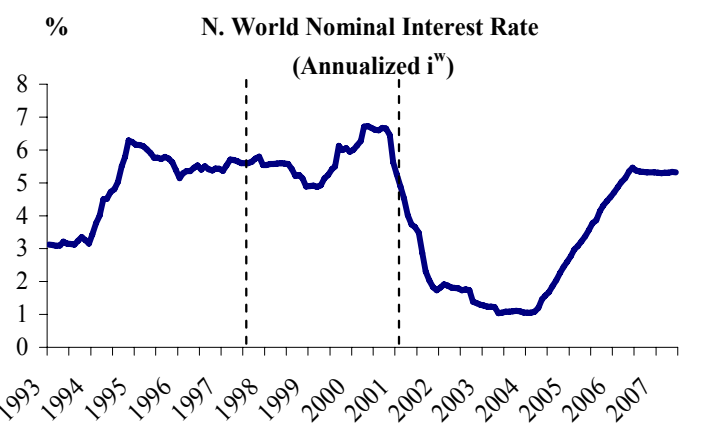

P. Inflation Rate (Annualized $\pi$ )

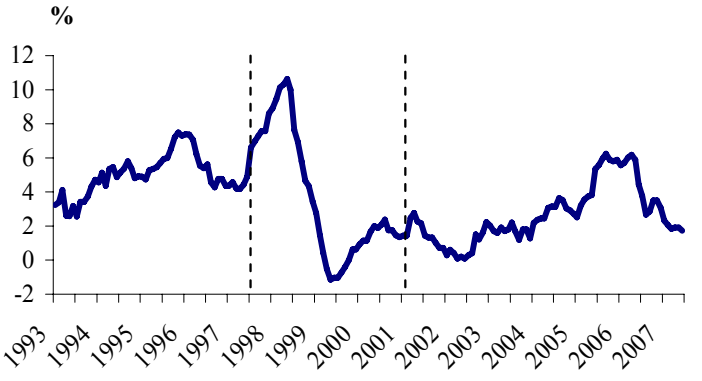




\section{Table 1: Descriptions and Data Sources of Variables}

\begin{tabular}{|c|c|c|}
\hline Variable & Description & Source \\
\hline $\begin{array}{l}Y=\text { Real Traded } \\
\text { Output } \\
\text { (Real Output) }\end{array}$ & $\begin{array}{l}Y=\text { Predicted monthly real output } \\
=a_{y}+b_{y} * \text { monthly manufacturing production index } \\
\text { - } \quad \text { Estimate } \mathrm{a}_{\mathrm{y}} \text { and } \mathrm{b}_{\mathrm{y}} \text { by regressing the actual } \\
\text { quarterly real output divided by } 3 \text { on the } \\
\text { average monthly manufacturing production } \\
\text { index for each quarter. } \\
\text { - } \\
\text { Predicted monthly real output }=\mathrm{a}_{\mathrm{y}}+\mathrm{b}_{\mathrm{y}} * \\
\text { monthly manufacturing production index. } \\
\text { If sum of the predicted monthly real output } \\
\text { within a quarter is not equal to the actual } \\
\text { quarterly real output, the difference is divided } \\
\text { by } 3 \text { and equally adjusted to the predicted } \\
\text { value of monthly real output. }\end{array}$ & $\begin{array}{l}\text { - Monthly seasonally } \\
\text { adjusted (SA) } \\
\text { manufacturing production } \\
\text { index from the Bank of } \\
\text { Thailand (BOT) } \\
\text { - Quarterly SA GDP at } 1988 \\
\text { prices from the Office of } \\
\text { National Economic and } \\
\text { Social Development Board } \\
\text { (NESDB) } \\
\text { (Traded output = Total } \\
\text { GDP subtracted by the } \\
\text { GDP from (1) financial } \\
\text { intermediations and (2) } \\
\text { real estate, renting and } \\
\text { business activities) }\end{array}$ \\
\hline $\begin{array}{l}\text { I = Real Private } \\
\text { Investment in } \\
\text { Traded Sectors } \\
\text { (Real Investment) }\end{array}$ & 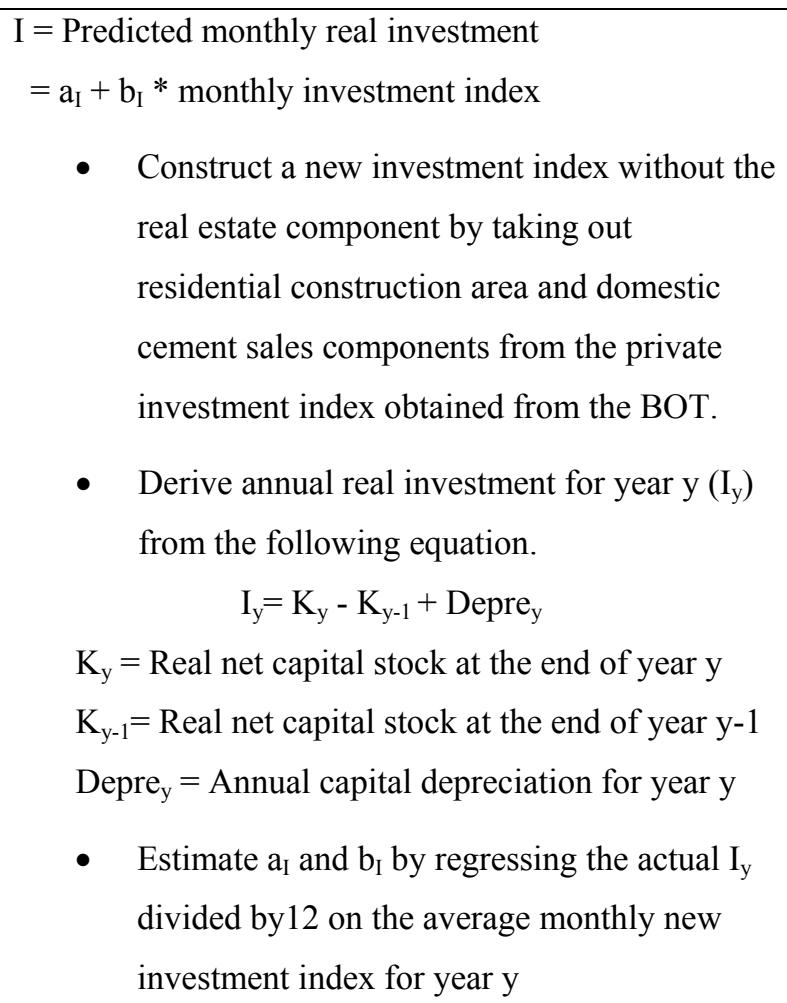 & $\begin{array}{l}\text { - Monthly private } \\
\text { investment index from } \\
1995 \text { to } 2007 \text { and the index } \\
\text { components from } 1993 \text { to } \\
2007 \text { from the BOT } \\
\text { - Annual SA net capital } \\
\text { stock and annual capital } \\
\text { depreciation of the private } \\
\text { sector at } 1988 \text { prices } \\
\text { (excluding the banking, } \\
\text { insurance, and real estate } \\
\text { sectors) from the NESDB }\end{array}$ \\
\hline
\end{tabular}




\begin{tabular}{|c|c|c|}
\hline Variable & Description & Source \\
\hline & $\begin{array}{l}\text { - Predicted monthly real investment }\left(\mathrm{I}_{\mathrm{m}}\right) \\
=\mathrm{a}_{\mathrm{I}}+\mathrm{b}_{\mathrm{I}} * \text { monthly new investment index } \\
\text { - If sum of } \mathrm{I}_{\mathrm{m}} \text { within a year is not equal to } \mathrm{I}_{\mathrm{y}} \text {, } \\
\text { the difference is divided by } 12 \text { and equally } \\
\text { adjusted to the predicted value of } \mathrm{I}_{\mathrm{m}}\end{array}$ & \\
\hline $\begin{array}{l}\mathrm{K}=\text { Real Net } \\
\text { Capital Stock of } \\
\text { the Private Sector } \\
\text { (Real Net Capital } \\
\text { Stock) }\end{array}$ & $\begin{array}{l}\mathrm{K}=\text { Predicted real net capital stock at the end of each } \\
\text { month according to the following equation } \\
\qquad \mathrm{K}_{\mathrm{my}}=\mathrm{K}_{\mathrm{my}-1}+\mathrm{I}_{\mathrm{my}}-\text { Depre }_{\mathrm{y}} / 12 \\
\mathrm{~K}_{\mathrm{my}}=\text { Real net capital stock at the end of month } \mathrm{m} \\
\quad \text { of year y } \\
\mathrm{K}_{\mathrm{my}-1}=\text { Real net capital stock at the end of month m-1 } \\
\quad \text { of year y } \\
\mathrm{I}_{\mathrm{my}}=\text { Predicted monthly real investment for } \\
\quad \text { month m of year y } \\
\text { Depre }_{\mathrm{y}}=\text { Annual capital depreciation for year y }\end{array}$ & $\begin{array}{l}\text { Annual SA net capital stock } \\
\text { and annual capital } \\
\text { depreciation of the private } \\
\text { sector at } 1988 \text { prices } \\
\text { (excluding the banking, } \\
\text { insurance, and real estate } \\
\text { sectors) from the NESDB }\end{array}$ \\
\hline $\begin{array}{l}\mathrm{C}=\text { Real Private } \\
\text { Consumption } \\
\text { (Real } \\
\text { Consumption) }\end{array}$ & $\begin{array}{l}\mathrm{C}=\text { Predicted monthly real consumption } \\
=\mathrm{a}_{\mathrm{c}}+\mathrm{b}_{\mathrm{c}} * \text { monthly consumption index } \\
\text { - } \quad \text { Estimate } \mathrm{a}_{\mathrm{c}} \text { and } \mathrm{b}_{\mathrm{c}} \text { by regressing the actual } \\
\\
\text { quarterly real consumption }\left(\mathrm{C}_{\mathrm{q}}\right) \text { divided by } 3 \\
\text { on the average monthly consumption index } \\
\text { for each quarter } \\
\text { - } \quad \text { Predicted monthly real consumption }\left(\mathrm{C}_{\mathrm{m}}\right) \\
=\mathrm{a}_{\mathrm{c}}+\mathrm{b}_{\mathrm{c}} * \text { monthly consumption index } \\
\text { - If sum of } \mathrm{C}_{\mathrm{m}} \text { within a quarter is not equal to } \\
\mathrm{C}_{\mathrm{q}} \text {, the difference is divided by } 3 \text { and equally } \\
\text { adjusted to the predicted value of } \mathrm{C}_{\mathrm{m}}\end{array}$ & $\begin{array}{l}\text { - Monthly private } \\
\text { consumption index from } \\
1995 \text { to } 2007 \text { and the index } \\
\text { components from } 1993 \text { to } \\
2007 \text { from the BOT. } \\
\text { This series is extended } \\
\text { backwards to } 1993 \text { using } \\
\text { the predicted value of the } \\
\text { index based on the } \\
\text { regression of the index on } \\
\text { its own components. } \\
\text { Q Quarterly SA private } \\
\text { consumption at } 1988 \\
\text { prices from the NESDB. }\end{array}$ \\
\hline $\begin{array}{l}\mathrm{M}=\text { Nominal } \\
\text { Monetary } \\
\text { Aggregate }\end{array}$ & $\mathrm{M}=$ Seasonally adjusted $\mathrm{M} 1$ & $\begin{array}{l}\text { Monthly M1 from } 1993 \text { to } \\
2006 \text { from the International } \\
\text { Financial Statistics of the } \\
\text { IMF (IMF-IFS). The series } \\
\text { is extended forwards to } 2007\end{array}$ \\
\hline
\end{tabular}




\begin{tabular}{|c|c|c|}
\hline Variable & Description & Source \\
\hline & & $\begin{array}{l}\text { using the predicted value of } \\
\text { M1 based on the regression } \\
\text { of M1 on narrow money (a } \\
\text { new measure replacing M1). }\end{array}$ \\
\hline $\begin{array}{l}\mathrm{b}=\text { Aggregate } \\
\text { Banks' Net } \\
\text { Foreign } \\
\text { Borrowing }\end{array}$ & $\begin{array}{l}\mathrm{b}=\text { Net foreign liabilities (Foreign liabilities - Foreign } \\
\text { assets) of all banks and finance companies } \\
\text { (This is equivalent to the stock of net international } \\
\text { capital flows via the banking sector) }\end{array}$ & $\begin{array}{l}\text { Aggregate foreign liabilities } \\
\text { and aggregate foreign assets } \\
\text { of all banks and finance } \\
\text { companies from the BOT. }\end{array}$ \\
\hline $\begin{array}{l}\varepsilon=\text { Nominal } \\
\text { Exchange Rate }\end{array}$ & $\varepsilon=$ Spot THB/USD exchange rate & $\begin{array}{l}\text { Monthly spot THB/USD } \\
\text { exchange rate (end of } \\
\text { period) from Datastream }\end{array}$ \\
\hline $\begin{array}{l}\mathrm{i}=\text { Domestic } \\
\text { Nominal Deposit } \\
\text { Rate }\end{array}$ & $\mathrm{i}=3$-month Thai baht deposit rate & $\begin{array}{l}\text { Monthly data from the IMF- } \\
\text { IFS }\end{array}$ \\
\hline $\begin{array}{l}i^{1}=\text { Domestic } \\
\text { Nominal Lending } \\
\text { Rate }\end{array}$ & $\mathrm{i}^{\mathrm{l}}=3$-month Thai baht lending rate & $\begin{array}{l}\text { Monthly data from the IMF- } \\
\text { IFS }\end{array}$ \\
\hline $\begin{array}{l}\mathrm{L}=\text { Employed } \\
\text { Labor }\end{array}$ & $\begin{array}{l}\mathrm{L}=\text { Monthly employed labor linearly interpolated } \\
\text { from semi-annual, quarterly, and monthly data and } \\
\text { seasonally adjusted using X-11 methodology. }\end{array}$ & $\begin{array}{l}\text { Semiannual (1993-1997), } \\
\text { quarterly (1998-2000), and } \\
\text { monthly (2001-2007) data } \\
\text { from the BOT }\end{array}$ \\
\hline $\begin{array}{l}\text { NPL }=\text { Banks' } \\
\text { Non-Performing } \\
\text { Loans to Total } \\
\text { Loans Ratio }\end{array}$ & $\begin{array}{l}\text { NPL from } 1998 \text { to } 2007=\text { Actual non-performing } \\
\text { loans to total loans ratio of all banks and finance } \\
\text { companies } \\
\text { NPL before } 1998 \text { = Predicted monthly NPL using } \\
\text { coincident economic index as an explanatory variable }\end{array}$ & $\begin{array}{l}\text { - Monthly NPL data from } \\
1998 \text { to } 2007 \text { from the } \\
\text { BOT } \\
\text { - Monthly coincident } \\
\text { economic index from } \\
1993 \text { to } 2007 \text { from the } \\
\text { BOT }\end{array}$ \\
\hline $\begin{array}{l}\mathrm{R}=\text { International } \\
\text { Reserves }\end{array}$ & $\begin{array}{l}\mathrm{R}=\text { International reserves, net of forward positions by } \\
\text { the BOT }\end{array}$ & Monthly data from the BOT \\
\hline $\begin{array}{l}\mathrm{i}^{\mathrm{w}}=\text { World } \\
\text { Nominal Interest } \\
\text { Rate }\end{array}$ & $\begin{array}{l}\mathrm{i}^{\mathrm{w}}=3 \text {-month US certificate of deposit (secondary } \\
\text { market) interest rate }\end{array}$ & $\begin{array}{l}\text { Monthly data from the IMF- } \\
\text { IFS }\end{array}$ \\
\hline
\end{tabular}




\begin{tabular}{lll}
\hline \multicolumn{1}{c}{ Variable } & \multicolumn{1}{c}{ Description } & \multicolumn{1}{c}{ Source } \\
\hline$\pi=$ Domestic & $\pi=$ Change in consumer price index (CPI) from the & Monthly change in CPI from \\
Inflation Rate & same month of the previous year & Datastream \\
& & (Source: Ministry of \\
& & Commerce) \\
\hline $\mathrm{P}=$ Price Level & $\mathrm{P}=\mathrm{CPI} / \mathrm{CPI}$ at 1988 prices & Monthly CPI from \\
& & Datastream \\
& & (Source: Ministry of \\
& & Commerce) \\
\hline
\end{tabular}




\section{Table 2: Summary Statistics for the Whole Sample Period}

This table reports the summary statistics of the variables used in the parameter estimation and the simulation exercises for the whole sample period from January 1993 to June 2007. Panel A presents the mean, the standard deviation, the median, the maximum, and the minimum of each variable in levels. Panel B exhibits those statistics of each variable in changes.

Panel A: Levels

\begin{tabular}{|c|c|c|c|c|c|c|c|}
\hline Variable & Description & Unit & Mean & $\begin{array}{l}\text { Standard } \\
\text { Deviation }\end{array}$ & Median & Maximum & Minimum \\
\hline $\mathrm{Y}^{*}$ & Real Output & (million baht) & $2,930,432$ & 468,344 & $2,816,136$ & $3,924,875$ & $2,078,155$ \\
\hline $\mathrm{K}$ & Real Net Capital Stock & (million baht) & $6,248,742$ & 753,548 & $6,466,197$ & $7,322,852$ & $4,182,282$ \\
\hline$I^{*}$ & Real Investment & (million baht) & 591,512 & 207,115 & 600,036 & $1,018,086$ & 275,733 \\
\hline $\mathrm{C}^{*}$ & Real Consumption & (million baht) & $1,740,724$ & 248,830 & $1,687,258$ & $2,235,394$ & $1,319,913$ \\
\hline $\mathrm{M} / \mathrm{P}$ & Real Monetary Aggregate & (million baht) & 309,940 & 78,423 & 278,239 & 446,168 & 189,954 \\
\hline $\mathrm{b}$ & Banks' Net Foreign Borrowing & (million USD) & 8,870 & 20,185 & 1,888 & 51,472 & $-23,402$ \\
\hline$\varepsilon / \mathrm{P}$ & Real FX rate & (baht/USD) & 20.72 & 2.84 & 20.91 & 32.27 & 15.94 \\
\hline$i^{*}$ & Nominal Deposit Rate & $(\%)$ & 5.69 & 3.93 & 4.50 & 14.00 & 1.00 \\
\hline$r^{* * *}$ & Real Deposit Rate & $(\%)$ & 2.05 & 2.71 & 1.88 & 6.90 & -3.57 \\
\hline $\mathrm{r}^{1 *, * *}$ & Real Lending Rate & $(\%)$ & 5.70 & 2.28 & 6.11 & 9.90 & 0.01 \\
\hline $\mathrm{L}$ & Employed Labor & (million) & 32.30 & 2.04 & 31.35 & 36.64 & 29.17 \\
\hline NPL & Banks' NPL & ( $\%$ of total loans) & 21.98 & 11.53 & 21.43 & 48.00 & 7.47 \\
\hline $\mathrm{R}$ & International Reserves & (million USD) & 36,227 & 16,279 & 31,523 & 82,521 & 1,144 \\
\hline$i^{w^{*}}$ & World Nominal Interest Rate & $(\%)$ & 4.25 & 1.74 & 5.08 & 6.73 & 1.04 \\
\hline$\pi^{*}$ & Inflation Rate & $(\%)$ & 3.63 & 2.46 & 3.41 & 10.64 & -1.14 \\
\hline
\end{tabular}

Panel B: Changes

\begin{tabular}{|c|c|c|c|c|c|c|c|}
\hline Variable & Description & Unit & Mean & $\begin{array}{l}\text { Standard } \\
\text { Deviation }\end{array}$ & Median & Maximum & Minimum \\
\hline$\Delta \mathrm{Y}^{*}$ & $\Delta$ Real Output & (million baht) & 10,429 & 52,022 & 8,905 & 150,061 & $-137,586$ \\
\hline$\Delta \mathrm{I}^{*}$ & $\Delta$ Real Investment & (million baht) & -823 & 26,640 & 1,369 & 118,245 & $-164,403$ \\
\hline$\Delta \mathrm{C}^{*}$ & $\Delta$ Real Consumption & (million baht) & 5,292 & 35,307 & 5,168 & 109,962 & $-120,367$ \\
\hline$\Delta \mathrm{M} / \mathrm{P}$ & $\Delta$ Real Monetary Aggregate & (million baht) & 1,430 & 8,959 & 1,253 & 37,820 & $-34,627$ \\
\hline$\Delta \mathrm{b}$ & $\Delta$ Banks' Net Foreign Borrowing & (million USD) & -169 & 1,380 & -47 & 2,724 & $-8,229$ \\
\hline$\Delta \varepsilon / \mathrm{P}$ & $\Delta$ Real FX rate & (baht/USD) & -0.023 & 0.860 & -0.070 & 4.711 & -6.098 \\
\hline$\Delta \mathrm{i}^{*}$ & $\Delta$ Nominal Deposit Rate & $(\%)$ & -0.042 & 0.516 & 0 & 2.250 & -3.250 \\
\hline$\Delta \mathrm{r}^{*, * *}$ & $\Delta$ Real Deposit Rate & $(\%)$ & -0.033 & 0.638 & -0.050 & 2.619 & -2.543 \\
\hline$\Delta \mathrm{r}^{1 * * * *}$ & $\Delta$ Real Lending Rate & $(\%)$ & -0.017 & 0.526 & -0.010 & 1.858 & -1.723 \\
\hline$\Delta \mathrm{L}$ & $\Delta$ Employed Labor & (million) & 0.035 & 0.309 & 0.026 & 1.113 & -1.330 \\
\hline$\triangle \mathrm{NPL}$ & 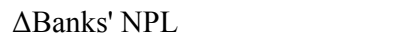 & ( $\%$ of total loans) & -0.161 & 1.534 & 0 & 5.000 & -9.000 \\
\hline$\Delta \mathrm{R}$ & $\Delta$ International Reserves & (million USD) & 350 & 1,937 & 367 & 5,431 & $-18,268$ \\
\hline$\Delta \mathrm{i}^{\mathrm{w}^{*}}$ & $\Delta$ World Nominal Interest Rate & $(\%)$ & 0.013 & 0.183 & 0 & 0.630 & -0.830 \\
\hline$\Delta \pi^{*}$ & $\Delta$ Inflation Rate & $(\%)$ & -0.009 & 0.545 & 0 & 1.720 & -2.360 \\
\hline
\end{tabular}

* These varialbles are annualized from monthly data.

** Real deposit rate $(r)=(1+\mathrm{i}) /(1+\pi)-1$ and real lending rate $\left(\mathrm{r}^{1}\right)=\left(1+\mathrm{i}^{\mathrm{l}}\right) /(1+\pi)-1$. 


\section{Table 3: Summary Statistics for Each Sub-Period}

This table reports the summary statistics of the variables used in the parameter estimation and the simulation exercises for each sub-period: (1) pre-crisis period from January 1993 to May 1997, (2) crisis (and reform) period from June 1997 to December 2000, and (3) post-crisis period from January 2001 to June 2007. Panel A presents the mean, the standard deviation, the median, the maximum, and the minimum of each variable in levels. Panel B exhibits those statistics of each variable in changes.

Panel A: Levels

\begin{tabular}{|c|c|c|c|c|c|c|c|c|}
\hline Variable & Description & Unit & Sub-Period & Mean & $\begin{array}{l}\text { Standard } \\
\text { Deviation }\end{array}$ & Median & Maximum & Minimum \\
\hline \multirow[t]{3}{*}{$\overline{\mathrm{Y}^{*}}$} & Real Output & (million baht) & Pre-Crisis & $2,524,669$ & 236,439 & $2,588,763$ & $2,838,823$ & $2,078,155$ \\
\hline & & & Crisis & $2,669,713$ & 135,030 & $2,707,662$ & $2,863,668$ & $2,403,981$ \\
\hline & & & Post-Crisis & $3,349,872$ & 340,025 & $3,371,901$ & $3,924,875$ & $2,815,521$ \\
\hline \multirow[t]{3}{*}{$\bar{K}$} & Real Net Capital Stock & (million baht) & Pre-Crisis & $5,322,520$ & 693,119 & $5,308,036$ & $6,443,335$ & $4,182,282$ \\
\hline & & & Crisis & $6,495,547$ & 48,144 & $6,481,420$ & $6,575,735$ & $6,440,882$ \\
\hline & & & Post-Crisis & $6,742,037$ & 281,202 & $6,653,367$ & $7,322,852$ & $6,456,754$ \\
\hline \multirow[t]{3}{*}{$\mathrm{I}^{*}$} & Real Investment & (million baht) & Pre-Crisis & 845,628 & 82,764 & 831,881 & $1,018,086$ & 703,275 \\
\hline & & & Crisis & 376,953 & 116,766 & 335,412 & 711,975 & 275,733 \\
\hline & & & Post-Crisis & 537,127 & 105,657 & 560,409 & 692,539 & 359,808 \\
\hline \multirow[t]{3}{*}{$\overline{\mathrm{C}^{*}}$} & Real Consumption & (million baht) & Pre-Crisis & $1,556,517$ & 130,188 & $1,570,712$ & $1,761,090$ & $1,319,913$ \\
\hline & & & Crisis & $1,563,775$ & 83,022 & $1,566,666$ & $1,726,461$ & $1,416,017$ \\
\hline & & & Post-Crisis & $1,963,438$ & 181,158 & $1,996,415$ & $2,235,394$ & $1,657,491$ \\
\hline \multirow[t]{3}{*}{$\overline{\mathrm{M} / \mathrm{P}}$} & Real Monetary & (million baht) & Pre-Crisis & 243,053 & 27,999 & 247,872 & 283,140 & 189,954 \\
\hline & Aggregate & & Crisis & 257,994 & 19,814 & 257,425 & 310,238 & 228,450 \\
\hline & & & Post-Crisis & 384,026 & 54,110 & 408,582 & 446,168 & 281,681 \\
\hline \multirow[t]{3}{*}{$\mathrm{b}$} & Banks' Net Foreign & (million USD) & Pre-Crisis & 28,776 & 15,025 & 30,964 & 51,472 & 5,775 \\
\hline & Borrowing & & Crisis & 16,082 & 15,071 & 11,684 & 48,322 & $-2,927$ \\
\hline & & & Post-Crisis & $-8,631$ & 5,203 & $-6,402$ & $-4,457$ & $-23,402$ \\
\hline \multirow[t]{3}{*}{$\overline{\varepsilon / \mathrm{P}}$} & Real FX rate & (baht/USD) & Pre-Crisis & 18.15 & 1.20 & 17.82 & 20.23 & 15.94 \\
\hline & & & Crisis & 22.75 & 2.56 & 22.10 & 32.27 & 16.51 \\
\hline & & & Post-Crisis & 21.35 & 2.52 & 21.44 & 25.29 & 16.06 \\
\hline \multirow[t]{3}{*}{$i^{*}$} & Nominal Deposit Rate & $(\%)$ & Pre-Crisis & 9.73 & 1.55 & 9.75 & 12.00 & 6.50 \\
\hline & & & Crisis & 6.88 & 3.79 & 5.00 & 14.00 & 3.00 \\
\hline & & & Post-Crisis & 2.28 & 1.21 & 2.00 & 4.75 & 1.00 \\
\hline \multirow[t]{3}{*}{$\mathrm{r}^{*, * *}$} & Real Deposit Rate & $(\%)$ & Pre-Crisis & 4.74 & 1.29 & 4.81 & 6.90 & 1.76 \\
\hline & & & Crisis & 3.10 & 1.55 & 2.78 & 6.58 & 0.61 \\
\hline & & & Post-Crisis & -0.35 & 1.63 & -0.27 & 2.18 & -3.57 \\
\hline \multirow[t]{3}{*}{$\mathrm{r}^{1 *, * *}$} & Real Lending Rate & $(\%)$ & Pre-Crisis & 7.27 & 1.11 & 7.52 & 8.94 & 4.85 \\
\hline & & & Crisis & 7.11 & 1.37 & 7.10 & 9.90 & 4.57 \\
\hline & & & Post-Crisis & 3.86 & 1.91 & 4.13 & 6.90 & 0.01 \\
\hline \multirow[t]{3}{*}{$\overline{\mathrm{L}}$} & Employed Labor & (million) & Pre-Crisis & 30.66 & 0.58 & 30.69 & 32.24 & 29.53 \\
\hline & & & Crisis & 30.77 & 0.58 & 30.76 & 31.89 & 29.17 \\
\hline & & & Post-Crisis & 34.25 & 1.39 & 34.50 & 36.64 & 31.15 \\
\hline \multirow[t]{3}{*}{$\overline{\mathrm{NPL}}$} & Banks' NPL & (\% of total & Pre-Crisis & 26.29 & 4.68 & 25.21 & 35.69 & 19.94 \\
\hline & & loans) & Crisis & 36.00 & 8.33 & 36.00 & 48.00 & 17.00 \\
\hline & & & Post-Crisis & 11.32 & 2.88 & 10.71 & 17.00 & 7.47 \\
\hline \multirow[t]{3}{*}{$\overline{\mathrm{R}}$} & International Reserves & (million USD) & Pre-Crisis & 30,306 & 6,932 & 29,906 & 39,903 & 5,297 \\
\hline & & & Crisis & 21,242 & 9,598 & 25,317 & 30,526 & 1,144 \\
\hline & & & Post-Crisis & 48,512 & 14,500 & 48,661 & 82,521 & 29,450 \\
\hline \multirow[t]{3}{*}{$\overline{i^{w^{*}}}$} & World Nominal & $(\%)$ & Pre-Crisis & 4.90 & 1.09 & 5.39 & 6.29 & 3.09 \\
\hline & Interest Rate & & Crisis & 5.74 & 0.56 & 5.60 & 6.73 & 4.88 \\
\hline & & & Post-Crisis & 2.99 & 1.63 & 2.53 & 5.46 & 1.04 \\
\hline \multirow[t]{3}{*}{$\pi^{*}$} & Inflation Rate & $(\%)$ & Pre-Crisis & 4.97 & 1.24 & 4.87 & 7.49 & 2.56 \\
\hline & & & Crisis & 3.78 & 3.71 & 2.08 & 10.64 & -1.14 \\
\hline & & & Post-Crisis & 2.64 & 1.68 & 2.24 & 6.24 & 0.10 \\
\hline
\end{tabular}


Panel B: Changes

\begin{tabular}{|c|c|c|c|c|c|c|c|c|}
\hline Variable & Description & Unit & Sub-Period & Mean & $\begin{array}{l}\text { Standard } \\
\text { Deviation }\end{array}$ & Median & Maximum & Minimum \\
\hline \multirow[t]{3}{*}{$\Delta \mathrm{Y}^{*}$} & $\Delta$ Real Output & (million baht) & Pre-Crisis & 14,022 & 41,170 & 14,396 & 150,061 & $-60,848$ \\
\hline & & & Crisis & 378 & 58,661 & 5,936 & 139,690 & $-137,586$ \\
\hline & & & Post-Crisis & 13,575 & 54,503 & 8,682 & 138,547 & $-105,965$ \\
\hline \multirow[t]{3}{*}{$\Delta \mathrm{I}^{*}$} & $\Delta$ Real Investment & (million baht) & Pre-Crisis & $-1,364$ & 38,107 & $-1,902$ & 118,245 & $-164,403$ \\
\hline & & & Crisis & $-6,705$ & 24,535 & $-1,424$ & 21,900 & $-122,659$ \\
\hline & & & Post-Crisis & 2,779 & 16,202 & 3,749 & 48,212 & $-67,192$ \\
\hline \multirow[t]{3}{*}{$\overline{\Delta C^{*}}$} & $\Delta$ Real Consumption & (million baht) & Pre-Crisis & 8,402 & 32,217 & 7,327 & 109,962 & $-69,845$ \\
\hline & & & Crisis & $-1,954$ & 41,441 & -154 & 100,662 & $-120,367$ \\
\hline & & & Post-Crisis & 7,213 & 33,479 & 5,020 & 74,466 & $-71,223$ \\
\hline \multirow[t]{3}{*}{$\Delta \mathrm{M} / \mathrm{P}$} & $\Delta$ Real Monetary & (million baht) & Pre-Crisis & 1,537 & 6,139 & 1,415 & 24,320 & $-13,113$ \\
\hline & Aggregate & & Crisis & 211 & 12,711 & 556 & 37,820 & $-34,627$ \\
\hline & & & Post-Crisis & 2,030 & 8,063 & 1,709 & 30,342 & $-31,436$ \\
\hline \multirow[t]{3}{*}{$\Delta \mathrm{b}$} & $\Delta$ Banks' Net Foreign & (million USD) & Pre-Crisis & 876 & 881 & 826 & 2,724 & -818 \\
\hline & Borrowing & & Crisis & $-1,265$ & 1,465 & $-1,004$ & 894 & $-8,229$ \\
\hline & & & Post-Crisis & -262 & 1,073 & -65 & 1,603 & $-4,661$ \\
\hline \multirow[t]{3}{*}{$\Delta \varepsilon / \mathrm{P}$} & $\Delta$ Real FX rate & (baht/USD) & Pre-Crisis & -0.082 & 0.133 & -0.074 & 0.129 & -0.829 \\
\hline & & & Crisis & 0.192 & 1.647 & 0.135 & 4.711 & -6.098 \\
\hline & & & Post-Crisis & -0.102 & 0.356 & -0.099 & 1.046 & -1.127 \\
\hline \multirow[t]{3}{*}{$\Delta \mathrm{i}^{*}$} & $\Delta$ Nominal Deposit Rate & $(\%)$ & Pre-Crisis & -0.005 & 0.518 & 0 & 1.500 & -2.000 \\
\hline & & & Crisis & -0.145 & 0.804 & 0 & 2.250 & -3.250 \\
\hline & & & Post-Crisis & -0.010 & 0.229 & 0 & 0.750 & -0.750 \\
\hline \multirow[t]{3}{*}{$\Delta \mathrm{r}^{*, * *}$} & $\Delta$ Real Deposit Rate & $(\%)$ & Pre-Crisis & -0.028 & 0.652 & -0.100 & 1.513 & -1.394 \\
\hline & & & Crisis & -0.073 & 0.840 & -0.200 & 2.619 & -2.543 \\
\hline & & & Post-Crisis & -0.015 & 0.492 & 0 & 1.443 & -1.511 \\
\hline \multirow[t]{3}{*}{$\Delta \mathrm{r}^{1 *, * *}$} & $\Delta$ Real Lending Rate & $(\%)$ & Pre-Crisis & 0.006 & 0.528 & -0.075 & 1.516 & -1.090 \\
\hline & & & Crisis & -0.050 & 0.611 & -0.189 & 1.858 & -1.723 \\
\hline & & & Post-Crisis & -0.013 & 0.479 & 0 & 1.447 & -1.614 \\
\hline \multirow[t]{3}{*}{$\Delta \mathrm{L}$} & $\Delta$ Employed Labor & (million) & Pre-Crisis & 0.033 & 0.193 & 0.019 & 0.432 & -0.377 \\
\hline & & & Crisis & -0.033 & 0.228 & -0.017 & 0.433 & -0.491 \\
\hline & & & Post-Crisis & 0.072 & 0.396 & 0.083 & 1.113 & -1.330 \\
\hline \multirow[t]{3}{*}{$\Delta \mathrm{NPL}$} & $\Delta$ Banks' NPL & $(\%$ of total & Pre-Crisis & -0.275 & 1.304 & -0.218 & 2.211 & -3.272 \\
\hline & & loans) & Crisis & -0.102 & 2.458 & 0 & 4.799 & -9.000 \\
\hline & & & Post-Crisis & -0.117 & 0.906 & 0 & 5.000 & -5.000 \\
\hline \multirow[t]{3}{*}{$\overline{\Delta R}$} & $\Delta$ International Reserves & (million USD) & Pre-Crisis & -320 & 2,945 & 240 & 1,686 & $\overline{-18,268}$ \\
\hline & & & Crisis & 587 & 1,003 & 353 & 3,747 & $-2,458$ \\
\hline & & & Post-Crisis & 667 & 1,285 & 523 & 5,431 & $-2,167$ \\
\hline \multirow[t]{3}{*}{$\Delta \mathrm{i}^{\mathrm{w}^{*}}$} & $\Delta$ World Nominal & $(\%)$ & Pre-Crisis & 0.049 & 0.167 & -0.005 & 0.500 & -0.240 \\
\hline & Interest Rate & & Crisis & -0.001 & 0.202 & 0.010 & 0.630 & -0.830 \\
\hline & & & Post-Crisis & -0.004 & 0.182 & 0 & 0.260 & -0.610 \\
\hline \multirow[t]{3}{*}{$\Delta \pi^{*}$} & $\Delta$ Inflation Rate & $(\%)$ & Pre-Crisis & 0.023 & 0.492 & 0.090 & 0.980 & -1.510 \\
\hline & & & Crisis & -0.072 & 0.720 & 0.110 & 1.720 & -2.360 \\
\hline & & & Post-Crisis & 0.005 & 0.465 & 0 & 1.520 & -1.450 \\
\hline
\end{tabular}

* These varialbles are annualized from monthly data.

$* *$ Real deposit rate $(r)=(1+\mathrm{i}) /(1+\pi)-1$ and real lending rate $\left(\mathrm{r}^{1}\right)=\left(1+\mathrm{i}^{\mathrm{l}}\right) /(1+\pi)-1$. 


\section{Table 4: Preliminary Correlation Analysis}

This table reports the correlations between the left-hand side (LHS) and the right-hand side (RHS) variables of the equilibrium conditions derived from the model over January 1993 to June 2007. In this table, Y $=$ Real output, $\mathrm{K}=\mathrm{Real}$ net capital stock, $\mathrm{I}=$ Real investment, $\mathrm{C}=$ Real consumption, $\mathrm{M} / \mathrm{P}=$ Real monetary aggregate, $\varepsilon / \mathrm{P}=$ Real exchange rate, $\mathrm{b}=$ Banks' net foreign borrowing, $\mathrm{L}=$ Employed labor, NPL $=$ Non-performing loans to total loans ratio, $\mathrm{r}^{1}=$ Real lending rate, $r=$ Real deposit rate, $\mathrm{i}=$ Nominal deposit rate, and $\mathrm{i}^{\mathrm{w}}=$ World nominal interest rate.

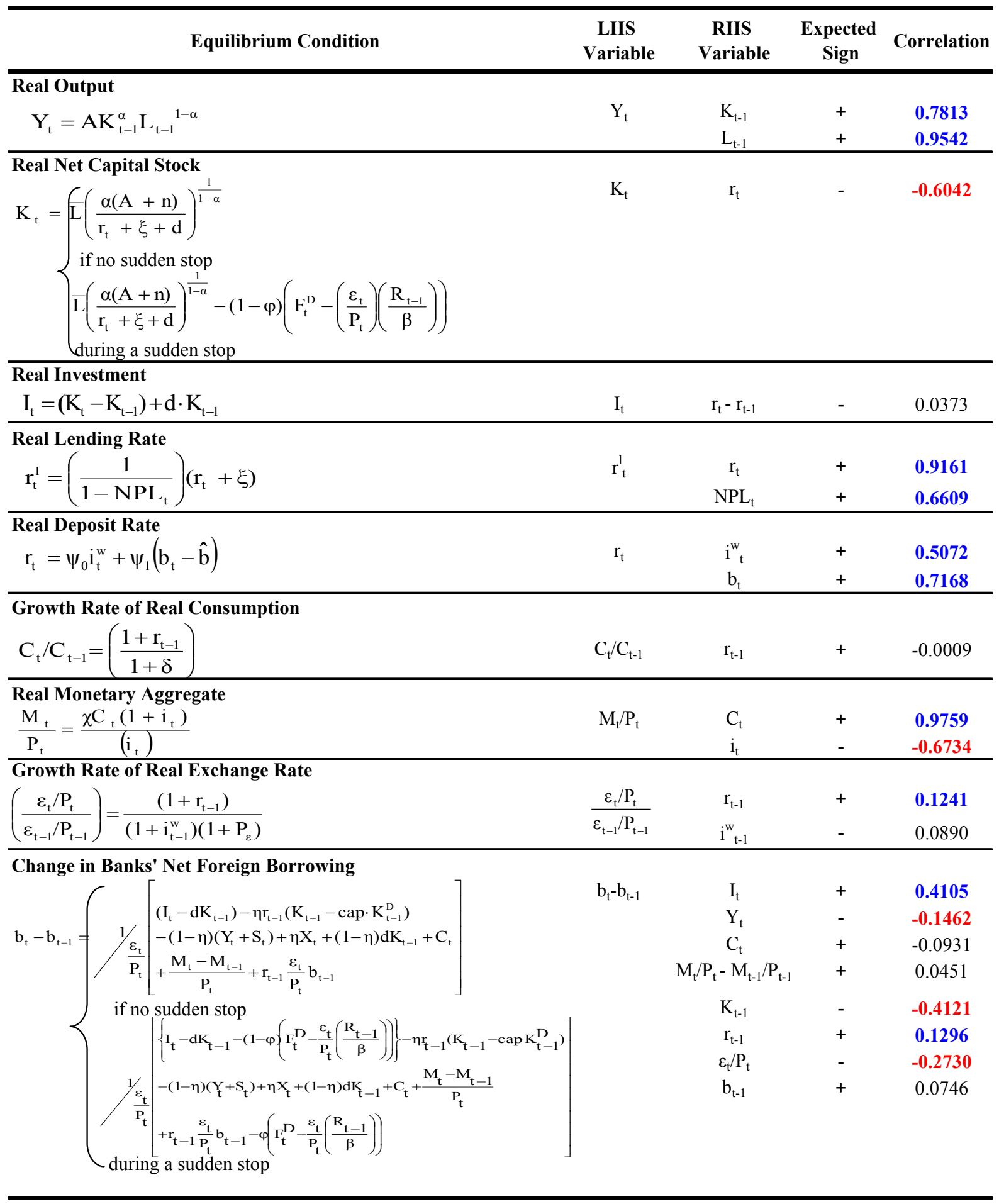




\section{Table 5: Correlations between Selected Macroeconomic Variables and Relevant Interest Rates}

This table compares the correlations between the selected macroeconomic variables and the relevant interest rates over January 1993 to June 2007 when using one-period interest rates versus eleven-year moving averages of interest rates.

\begin{tabular}{cccccc}
\hline \multicolumn{1}{c}{ Variables } & & $\begin{array}{c}\text { Expected } \\
\text { Sign }\end{array}$ & $\begin{array}{c}\text { One-Period } \\
\text { Interest } \\
\text { Rates }\end{array}$ & $\begin{array}{c}\text { Eleven-Year } \\
\text { Moving Averages } \\
\text { of Interest Rates }\end{array}$ \\
\hline Real Net Capital Stock $\left(\mathrm{K}_{\mathrm{t}}\right)$ & vs. & Real Deposit Rate $\left(\mathrm{r}_{\mathrm{t}}\right)$ & - & -0.6042 & -0.8742 \\
\hline $\begin{array}{c}\text { Real Investment }\left(\mathrm{I}_{\mathrm{t}}\right) \\
\text { Growth Rate of Real }\end{array}$ & vs. & $\begin{array}{c}\text { Change in Real } \\
\text { Deposit Rate }\left(\mathrm{r}_{\mathrm{t}}-\mathrm{r}_{\mathrm{t}-1}\right)\end{array}$ & - & 0.0373 & -0.2742 \\
\hline $\begin{array}{c}\text { Real Monsumption }\left(\mathrm{C}_{\mathrm{t}} / \mathrm{C}_{\mathrm{t}-1}\right) \\
\left(\mathrm{M}_{\mathrm{t}} / \mathrm{P}_{\mathrm{t}}\right)\end{array}$ & vs. & $\begin{array}{c}\text { Lagged Real Deposit } \\
\text { Rate }\left(\mathrm{r}_{\mathrm{t}-1}\right)\end{array}$ & + & -0.0009 & 0.0138 \\
\hline
\end{tabular}




\section{Table 6: Exogenously-Determined Parameters}

This table presents the values of exogenously-determined parameters and describes how they are derived. Those parameter values are generally obtained from related studies or calibrated using long-run data relations.

\begin{tabular}{|c|c|c|}
\hline Parameter & Value & Calculation/Source \\
\hline$\alpha$ & 0.31238 & $\begin{array}{l}\text { The average income share of capital over 1993-2005. } \\
\text { Source: Jetin (2007) }\end{array}$ \\
\hline A & 168 & Solve for the value of $\mathrm{A}$ that makes the long-run relation $\overline{\mathrm{Y}}=\mathrm{A} \overline{\mathrm{K}}^{\alpha} \overline{\mathrm{L}}^{-\alpha}$ hold. \\
\hline cap & 0.48 & $\begin{array}{l}1 \text { - The average ratio of bank loans to total external finance over 1993- } 2007 . \\
\text { [Total external finance = Sum of bank loans, stock market capitalization, and } \\
\text { outstanding of domestic bonds] } \\
\text { Source: Akrasanee (2008) }\end{array}$ \\
\hline d & 0.0051 & $\begin{array}{l}\text { The average yearly capital depreciation rate of the private sector over } \\
\text { 1993- } 2007 \text { divided by } 12 . \\
\text { Source: The Office of National Economic and Social Development Board } \\
\text { (NESDB) }\end{array}$ \\
\hline$\hat{b}$ & 0 & $\begin{array}{l}\text { Assumed to be zero, i.e., when the aggregate level of banks' net foreign } \\
\text { borrowing is zero, the interest rate applied to banks' foreign lending and } \\
\text { borrowing transactions is exactly equal to the world interest rate. }\end{array}$ \\
\hline$\xi$ & 0.002 & Solve for the value of $\xi$ that makes the long-run relation $\overline{\mathrm{r}}^{1}=\left(\frac{\overline{\mathrm{r}}+\xi}{1-\overline{\mathrm{NPL}}}\right)$ hold. \\
\hline$\chi$ & 0.01 & $\begin{array}{l}\text { Solve for the value of } \chi \text { that makes the long-run relation } \\
\frac{\overline{\mathrm{M}}}{\mathrm{P}}=\chi \overline{\mathrm{C}} \frac{(1+\overline{\mathrm{r}})(1+\bar{\pi})}{(1+\overline{\mathrm{r}})(1+\bar{\pi})-1} \quad \text { hold. }\end{array}$ \\
\hline$\delta$ & 0.0017 & Use the value of $\delta$ that makes the long-run relation $\delta=\overline{\mathrm{r}}$ hold. \\
\hline$\beta$ & 1 & $\begin{array}{l}\text { This is the worst case scenario in which foreign creditors expect the country's } \\
\text { international reserves to cover the full amount of banks' cumulative NPL losses. }\end{array}$ \\
\hline$\eta$ & $9.79 \%$ & $\begin{array}{l}\text { The weighted average personal income tax rate from a survey in } 1992 . \\
\text { Source: Poapongsakorn, Charnvitayapong, Laovakul \& Suksiriserekul, Dahlby } \\
\text { (2000) }\end{array}$ \\
\hline$\varphi$ & 0 & $\begin{array}{l}\text { This is the worst case scenario in which the government provides the least } \\
\text { support to banks during a sudden stop. The government support during a } \\
\text { sudden stop however does not include the transfers of the remaining cumulative } \\
\text { NPL losses to the government to clean up the banking system during the bailout } \\
\text { period. }\end{array}$ \\
\hline
\end{tabular}




\section{Table 7: Parameter Estimates from Partial-Sample GMM Estimation}

This table reports the estimated values of the parameters measuring the severity of moral hazard problems and the related parameters for each sub-period from the partial-sample GMM estimation. The loan loss provisioning ratio (v) indicates the degree of the moral hazard problem at the bank level. The level of government subsidies (if positive) or taxes (if negative) (n) measures the severity of the moral hazard problem at the corporate level. The interest rate sensitivity to the aggregate level of banks' net foreign borrowing $\left(\psi_{1}\right)$ and the expected exchange rate deviation from the uncovered interest rate parity (UIP) measure the degree of the moral hazard problems at the international level. The related parameters, which may change over time, include the interest rate sensitivity to the world interest rate $\left(\psi_{0}\right)$, the weight given to contemporary investment predicted by the model $\left(\operatorname{Inv}_{0}\right)$, and the weight given to lagged investment in the investment equation $\left(\operatorname{Inv}_{1}\right)$. The approximate standard errors, t-statistics, p-values, as well as the J-statistic for over-identifying restrictions test are also reported.

\begin{tabular}{|c|c|c|c|c|c|c|}
\hline Parameter & Sub-Period & \multicolumn{2}{|c|}{ Estimate } & \multirow{2}{*}{$\begin{array}{r}\begin{array}{l}\text { Approx. } \\
\text { Std. Err. }\end{array} \\
0.0763\end{array}$} & \multirow{2}{*}{$\begin{array}{r}\text { T-Statistic } \\
6.84\end{array}$} & \multirow{2}{*}{$\begin{array}{r}\begin{array}{r}\text { Approx. } \\
\text { P-Value }\end{array} \\
<.0001\end{array}$} \\
\hline Loan Loss Provisioning & Pre-Crisis $\left(v_{\text {sub1 }}\right)$ & 0.5215 & $* * *$ & & & \\
\hline \multirow[t]{2}{*}{ Ratio (v) } & Crisis $\left(v_{\text {sub2 }}\right)$ & 0 & + & - & . & \\
\hline & Post-Crisis $\left(v_{\text {sub3 }}\right)$ & 1 & + & - & 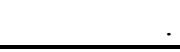 & \\
\hline Government Subsidies or & Pre-Crisis $\left(\mathrm{n}_{\mathrm{sub} 1}\right)$ & -3.84 & $* * *$ & 0.85 & -4.49 & $<.0001$ \\
\hline \multirow[t]{2}{*}{ Taxes (n) } & Crisis $\left(\mathrm{n}_{\mathrm{sub} 2}\right)$ & -13.01 & $* * *$ & 1.67 & -7.78 & $<.0001$ \\
\hline & Post-Crisis $\left(\mathrm{n}_{\mathrm{sub} 3}\right)$ & -29.02 & $* * *$ & 1.24 & -23.37 & $<.0001$ \\
\hline Interest Rate Sensitivity to & Pre-Crisis $\left(\psi_{0, \text { sub1 }}\right)$ & 1.1797 & $* * *$ & 0.2370 & 4.98 & $<.0001$ \\
\hline \multirow[t]{2}{*}{ the World Interest Rate $\left(\psi_{0}\right)$} & Crisis $\left(\psi_{0, \text { sub2 }}\right)$ & -0.1645 & & 0.1114 & -1.48 & 0.1416 \\
\hline & Post-Crisis $\left(\psi_{0, \text { sub3 }}\right)$ & 0.0585 & & 0.1135 & 0.52 & 0.6071 \\
\hline Interest Rate Sensitivity to & Pre-Crisis $\left(\psi_{1, \text { sub } 1}\right)$ & -0.1500 & & 0.5460 & -0.27 & 0.7890 \\
\hline the Aggregate Level of Banks' & Crisis $\left(\psi_{1, \text { sub } 2}\right)$ & 0.8360 & $* *$ & 0.3540 & 2.36 & 0.0193 \\
\hline Net Foreign Borrowing $\left(\psi_{1}\right)$ & Post-Crisis $\left(\psi_{1, \mathrm{sub} 3}\right)$ & 1.4610 & $* *$ & 0.6860 & 2.13 & 0.0347 \\
\hline Expected FX Rate Deviation & Pre-Crisis $\left(\mathrm{P}_{\varepsilon, \text { sub1 }}\right)$ & 0.0044 & $* * *$ & 0.0004 & 10.62 & $<.0001$ \\
\hline from the Uncovered Interest & Crisis $\left(\mathrm{P}_{\varepsilon, \mathrm{sub} 2}\right)$ & -0.0095 & $* * *$ & 0.0023 & -4.12 & $<.0001$ \\
\hline Rate Parity $\left(\mathrm{P}_{\varepsilon}\right)$ & Post-Crisis $\left(\mathrm{P}_{\varepsilon, \mathrm{sub} 3}\right)$ & 0.0014 & & 0.0011 & 1.37 & 0.1714 \\
\hline Weight Given to & Pre-Crisis $\left(\operatorname{Inv}_{0, \text { sub1 }}\right)$ & 0.0682 & $* *$ & 0.0269 & 2.53 & 0.0122 \\
\hline Contemporary Investment & Crisis $\left(\operatorname{Inv}_{0, \text { sub2 }}\right)$ & 0.0267 & $* *$ & 0.0132 & 2.02 & 0.0450 \\
\hline Predicted by the Model $\left(\operatorname{Inv}_{0}\right)$ & Post-Crisis $\left(\operatorname{Inv}_{0, \text { sub3 }}\right)$ & 0.0796 & $* * *$ & 0.0269 & 2.96 & 0.0035 \\
\hline Weight Given to & Pre-Crisis $\left(\operatorname{Inv}_{1, \text { sub } 1}\right)$ & 0.9508 & $* * *$ & 0.0187 & 50.85 & $<.0001$ \\
\hline \multirow[t]{4}{*}{ Lagged Investment $\left(\operatorname{Inv}_{1}\right)$} & Crisis $\left(\operatorname{Inv}_{1, \text { sub } 2_{2}}\right)$ & 0.9460 & $* * *$ & 0.0184 & 51.39 & $<.0001$ \\
\hline & Post-Crisis $\left(\operatorname{Inv}_{1, \text { sub3 }}\right)$ & 0.8742 & $* * *$ & 0.0441 & 19.82 & $<.0001$ \\
\hline & \multirow{2}{*}{\multicolumn{5}{|c|}{$\begin{array}{l}\text { J-Statistic for the test of overidentifying restrictions: } \\
\text { value of chi-square with } 108-21=87 \text { degrees of freedom : }\end{array}$}} & 66.9335 \\
\hline & & & & & & 0.9458 \\
\hline
\end{tabular}

sub1, sub2, sub3 denote pre-crisis, crisis, and post-crisis periods, respectively.

$* * *, * *, * \quad$ indicate significance at the $1 \%, 5 \%$, and $10 \%$ confidence levels, respectively.

$+$

The estimated value is below (above) the lower (upper) bound. Hence, the lower (upper)

bound value is assigned to this parameter. The standard error is not reported. 


\section{Table 8: Wald Statistics for Structural Break Tests}

This table reports the Wald statistics and the p-values for the structural break tests. Particularly, the tests for the differences in the values of the parameters measuring the severity of moral hazard problems are conducted for pre-crisis and post-crisis periods, pre-crisis and crisis periods, as well as crisis and post-crisis periods. The tests are also undertaken for each parameter as well as all parameters in combination. The level of government subsidies (if positive) or taxes (if negative) (n) measures the severity of the moral hazard problem at the corporate level. The interest rate sensitivity to the aggregate level of banks' net foreign borrowing $\left(\psi_{1}\right)$ and the expected exchange rate deviation from the uncovered interest rate parity (UIP) measure the degree of the moral hazard problems at the international level. The related parameters, which may change over time, include the interest rate sensitivity to the world interest rate $\left(\psi_{0}\right)$, the weight given to contemporary investment predicted by the model $\left(\operatorname{Inv}_{0}\right)$, and the weight given to lagged investment in the investment equation $\left(\operatorname{Inv}_{1}\right)$. The tests for the differences in the loan loss provisioning ratio $(v)$, which measures the severity of the moral hazard problem at the bank level, cannot be conducted since the lower bound and upper bound values are assigned to the loan loss provisioning ratios for the crisis and post-crisis periods, respectively.

\begin{tabular}{|c|c|c|}
\hline Test & Wald Statictic & P-Value \\
\hline \multicolumn{3}{|c|}{ Pre-Crisis VS. Post-Crisis Periods } \\
\hline $\mathrm{n}_{\mathrm{sub} 1}=\mathrm{n}_{\mathrm{sub} 3}$ & $279.19 * * *$ & $<.0001$ \\
\hline$\psi_{0, \mathrm{sub} 1}=\psi_{0, \mathrm{sub} 3}$ & $18.21 * * *$ & $<.0001$ \\
\hline$\psi_{1, \mathrm{sub} 1}=\psi_{1, \mathrm{sub} 3}$ & $3.36 *$ & 0.0669 \\
\hline $\mathrm{P}_{\varepsilon, \mathrm{sub} 1}=\mathrm{P}_{\varepsilon, \mathrm{sub} 3}$ & $6.80 * * *$ & 0.0091 \\
\hline $\operatorname{Inv}_{0, \text { sub1 }}=\operatorname{Inv}_{0, \text { sub3 }}$ & 0.09 & 0.7641 \\
\hline $\operatorname{Inv}_{1, \mathrm{sub} 1}=\operatorname{Inv}_{1, \mathrm{sub} 3}$ & 2.56 & 0.1097 \\
\hline All parameters $_{\text {sub1 }}=$ All parameters sub3 $_{\text {sul }}$ & $313.56 * * *$ & $<.0001$ \\
\hline \multicolumn{3}{|c|}{ Pre-Crisis VS. Crisis Periods } \\
\hline $\mathrm{n}_{\mathrm{sub} 1}=\mathrm{n}_{\mathrm{sub} 2}$ & $23.42 * * *$ & $<.0001$ \\
\hline$\psi_{0, \text { sub1 }}=\psi_{0, \text { sub2 }}$ & $26.35 * * *$ & $<.0001$ \\
\hline$\psi_{1, \mathrm{sub} 1}=\psi_{1, \mathrm{sub} 2}$ & 2.28 & 0.1312 \\
\hline $\mathrm{P}_{\varepsilon, \mathrm{sub} 1}=\mathrm{P}_{\varepsilon, \mathrm{sub} 2}$ & $35.12 * * *$ & $<.0001$ \\
\hline $\operatorname{Inv}_{0, \text { sub1 }}=\operatorname{Inv}_{0, \text { sub2 }}$ & 1.92 & 0.1663 \\
\hline $\operatorname{Inv}_{1, \mathrm{sub} 1}=\operatorname{Inv}_{1, \mathrm{sub} 2}$ & 0.03 & 0.8549 \\
\hline All parameters $_{\text {sub1 }}=$ All parameters sub2 $_{\text {sura }}$ & $128.01 * * *$ & $<.0001$ \\
\hline \multicolumn{3}{|c|}{ Crisis VS. Post-Crisis Periods } \\
\hline $\mathrm{n}_{\mathrm{sub} 2}=\mathrm{n}_{\mathrm{sub} 3}$ & $59.12 * * *$ & $<.0001$ \\
\hline$\psi_{0, \text { sub2 }}=\psi_{0, \text { sub3 }}$ & 1.97 & 0.1609 \\
\hline$\psi_{1, \mathrm{sub} 2}=\psi_{1, \mathrm{sub} 3}$ & 0.66 & 0.4181 \\
\hline $\mathrm{P}_{\varepsilon, \mathrm{sub} 2}=\mathrm{P}_{\varepsilon, \mathrm{sub} 3}$ & $18.66 * * *$ & $<.0001$ \\
\hline $\operatorname{Inv}_{0, \text { sub2 }}=\operatorname{Inv}_{0, \text { sub3 }}$ & $3.12 *$ & 0.0774 \\
\hline $\operatorname{Inv}_{1, \mathrm{sub} 2}=\operatorname{In} v_{1, \mathrm{sub} 3}$ & 2.26 & 0.1328 \\
\hline All parameters sub2 $=$ All parameters pub3 $_{\text {sura }}$ & $120.67 * * *$ & $<.0001$ \\
\hline
\end{tabular}

sub1, sub2, sub3 denote pre-crisis, crisis, and post-crisis periods, respectively.

$* * *, * *, * \quad$ indicate significance at the $1 \%, 5 \%$, and $10 \%$ confidence levels, respectively. 


\section{Table 9: Simulation Scenarios}

This table describes the scenarios used in the simulation exercises to assess the impact of changes in the quality of institutions and domestic policies to reduce moral hazard problems on the direct and indirect costs or benefits of international capital flows to an open economy like Thailand. The base scenario serves as the benchmark case where all estimated parameter values are set at the pre-crisis levels. In group A scenarios, only one aspect of the moral hazard problems is adjusted to the post-crisis level. In group B scenarios, the loan loss provisioning ratio (v), which measures the severity of the moral hazard problem at the bank level, and another aspect of the moral hazard problems are concurrently adjusted to the post-crisis levels. Scenario C1 uses different parameter values (as derived from the partial-sample GMM estimation) for each sub-period.

\begin{tabular}{|c|c|c|c|c|c|c|c|c|}
\hline \multirow[t]{2}{*}{ Scenario } & \multirow[t]{2}{*}{ Description } & \multicolumn{7}{|c|}{ Parameter Value Used } \\
\hline & & v & $\mathbf{n}$ & $\Psi_{0}$ & $\Psi_{1}$ & $\mathbf{P}_{\varepsilon}$ & $\operatorname{Inv}_{0}$ & $\operatorname{Inv}_{1}$ \\
\hline Base & All parameters at the pre-crisis values & 0.5215 & -3.84 & 1.1797 & 0 & 0.0044 & 0.0682 & 0.9508 \\
\hline A1 & $\uparrow$ Loan loss provisioning ratio ( $v_{\text {sub1 }}$ is increased to $v_{\text {sub3 }}$ ) & 1 & -3.84 & 1.1797 & 0 & 0.0044 & 0.0682 & 0.9508 \\
\hline A2 & $\downarrow$ Government subsidies or $\uparrow$ taxes $\left(\mathrm{n}_{\text {sub } 1}\right.$ is reduced to $\mathrm{n}_{\text {sub3 }}$ ) & 0.5215 & -29.02 & 1.1797 & 0 & 0.004398 & 0.0682 & 0.9508 \\
\hline $\mathbf{A 3}$ & $\begin{array}{l}\uparrow \text { Interest rate sensitivity to the aggregate level of banks' net foreign borrowing } \\
\left(\Psi_{1, \text { sub1 } 1} \text { is increased to } \Psi_{1, \text { sub3 }} \text {, and } \Psi_{0, \text { sub } 1} \text { is decreased to } \Psi_{0, \text { sub3 }}\right)\end{array}$ & 0.5215 & -3.84 & $\mathbf{0}$ & 1.4610 & 0.004398 & 0.0682 & 0.9508 \\
\hline A4 & $\downarrow \mathrm{FX}$ rate deviation from the uncovered interest rate parity $\left(\mathrm{P}_{\varepsilon, \text { sub } 1}\right.$ is reduced to $\left.\mathrm{P}_{\varepsilon, \text { sub3 }}\right)$ & 0.5215 & -3.84 & 1.1797 & 0 & $\mathbf{0}$ & 0.0682 & 0.9508 \\
\hline B1 & Scenario A1 + A2 & 1 & -29.02 & 1.1797 & 0 & 0.004398 & 0.0682 & 0.9508 \\
\hline B2 & Scenario A1 + A3 & 1 & -3.84 & $\mathbf{0}$ & 1.4610 & 0.004398 & 0.0682 & 0.9508 \\
\hline B3 & Scenario A1 + A4 & 1 & -3.84 & 1.1797 & 0 & $\mathbf{0}$ & 0.0682 & 0.9508 \\
\hline \multirow[t]{4}{*}{ C1 } & Different parameter values for each sub-period & & & & & & & \\
\hline & - Pre-crisis period & 0.5215 & -3.84 & 1.1797 & 0 & 0.0044 & 0.0682 & 0.9508 \\
\hline & - Crisis period & 0 & -13.01 & 0 & 0.8360 & -0.0095 & 0.0267 & 0.9460 \\
\hline & - Post-crisis period & 1 & -29.02 & 0 & 1.4610 & 0 & 0.0796 & 0.8742 \\
\hline
\end{tabular}




\section{Table 10: Direct and Indirect Costs in Comparison with the Actual Data}

This table reports the estimated direct and indirect costs or benefits of international capital flows under different moral hazard scenarios as described in table 9. The actual direct and indirect costs or benefits to Thailand during January 1993 to June 2007 are also reported for comparison. The estimated direct costs are the sum of banks' NPL losses transferred to the government while the actual direct costs are the sum of actual government lending to the Financial Institutions Development Funds (FIDF). The indirect costs or benefits are the effect of international capital flows and moral hazard problems on both the level and growth of output. The average annual output and the average annual output growth rate are annualized from monthly output and monthly output growth rate, respectively. \% of output is based on the output of June 2007. 'No Time Value' means that the time value of money is not taken into account while 'Future Value' means that the amount in each period $t$ is multiplied by $(1+\text { average real deposit rate })^{\wedge}(T-t)$ to account for the time value of money, where $T-t$ is the number of periods between period and June 2007.

Unit: Million Baht

\begin{tabular}{|c|c|c|c|c|c|c|c|}
\hline \multirow[t]{2}{*}{ Scenario } & \multicolumn{2}{|c|}{ Amount } & \multicolumn{2}{|c|}{$\%$ of Output } & \multicolumn{2}{|c|}{ Avg Output } & \multirow{2}{*}{$\begin{array}{c}\text { Avg } \\
\text { Output } \\
\text { Growth } \\
\text { Rate (\%) }\end{array}$} \\
\hline & No Time Value & Future Value & No Time Value & Future Value & No Time Value & Future Value & \\
\hline Base: All parameters at the pre-crisis values & 460,209 & 551,283 & $11.79 \%$ & $14.12 \%$ & $3,098,466$ & $3,562,214$ & $3.21 \%$ \\
\hline A1. $\uparrow$ Loan loss provisioning ratio & - & - & $0 \%$ & $0 \%$ & $3,098,663$ & $3,562,448$ & $3.21 \%$ \\
\hline A2. $\downarrow$ Government subsidies or $\uparrow$ taxes & 427,912 & 512,985 & $11.64 \%$ & $13.95 \%$ & $2,988,725$ & $3,441,424$ & $2.79 \%$ \\
\hline A3. $\uparrow$ Interest rate sensitivity to the aggregate level of banks' net foreign borrowing & 197,656 & 238,267 & $5.06 \%$ & $6.11 \%$ & $3,102,801$ & $3,567,176$ & $3.21 \%$ \\
\hline A4. $\downarrow$ FX rate deviation from the uncovered interest rate parity & 461,023 & 552,054 & $11.81 \%$ & $14.14 \%$ & $3,098,473$ & $3,562,222$ & $3.21 \%$ \\
\hline B1. Scenario A1 + A2 & - & - & $0 \%$ & $0 \%$ & $2,988,930$ & $3,441,666$ & $2.79 \%$ \\
\hline B2. Scenario A1 + A3 & - & - & $0 \%$ & $0 \%$ & $3,102,585$ & $3,566,944$ & $3.21 \%$ \\
\hline B3. Scenario A1 + A4 & - & - & $0 \%$ & $0 \%$ & $3,098,663$ & $3,562,448$ & $3.21 \%$ \\
\hline C1. Different parameter values for each sub-period & 596,703 & 714,076 & $18.02 \%$ & $21.56 \%$ & $2,919,919$ & $3,372,412$ & $2.06 \%$ \\
\hline Actual Data & $1,274,561$ & $1,433,792$ & $32.69 \%$ & $36.78 \%$ & $2,935,264$ & $3,369,606$ & $4.40 \%$ \\
\hline
\end{tabular}




\section{Table 11: Direct, Indirect and Total Costs Relative to the Base Scenario}

This table reports the estimated direct, indirect, and total costs or benefits of international capital flows under different moral hazard scenarios relative to the base scenario. The relative direct costs are the difference between the sum of the bailout costs in each scenario and the sum of the bailout costs in the base scenario. The relative indirect costs $(-)$ or benefits $(+)$ are the difference between the sum of the output in each scenario and the sum of the output in the base scenario. The sum of the output $\approx$ The average annual output in table $10 * 173$ periods $/ 12$. The relative total costs are the sum of the relative direct costs and the relative indirect costs. 'No Time Value' means that the time value of money is not taken into account while 'Future Value' means that the amount in each period $t$ is multiplied by (1+ average real deposit rate $)^{\wedge}(T-t)$ to account for the time value of money, where $T-t$ is the number of periods between period $t$ and June 2007.

Unit: Million Baht

\begin{tabular}{|c|c|c|c|c|c|c|}
\hline \multirow{3}{*}{ Scenario } & \multicolumn{6}{|c|}{ Benefits(+) or Costs(-) Relative to the Base Case } \\
\hline & \multicolumn{2}{|c|}{ Direct Costs } & \multicolumn{2}{|c|}{ Indirect Costs } & \multicolumn{2}{|c|}{ Total Costs } \\
\hline & No Time Value & Future Value & No Time Value & Future Value & No Time Value & Future Value \\
\hline A1. $\uparrow$ Loan loss provisioning ratio & 460,209 & 551,283 & 2,843 & 3,375 & 463,052 & 554,659 \\
\hline A2. $\downarrow$ Government subsidies or $\uparrow$ taxes & 32,296 & 38,298 & $(1,582,088)$ & $(1,741,385)$ & $(1,549,792)$ & $(1,703,087)$ \\
\hline A3. $\uparrow$ Interest rate sensitivity to the aggregate level of banks' net foreign borrowing & 262,552 & 313,016 & 62,497 & 71,533 & 325,049 & 384,550 \\
\hline A4. $\downarrow$ FX rate deviation from the uncovered interest rate parity & $(814)$ & $(771)$ & 101 & 121 & (713) & (649) \\
\hline B1. Scenario A1 + A2 & 460,209 & 551,283 & $(1,579,146)$ & $(1,737,893)$ & $(1,118,937)$ & $(1,186,610)$ \\
\hline B2. Scenario A1 + A3 & 460,209 & 551,283 & 59,383 & 68,194 & 519,592 & 619,477 \\
\hline B3. Scenario A1 + A4 & 460,209 & 551,283 & 2,843 & 3,375 & 463,052 & 554,659 \\
\hline C1. Different parameter values for each sub-period & $(136,495)$ & $(162,792)$ & $(2,574,049)$ & $(2,736,305)$ & $(2,710,544)$ & $(2,899,097)$ \\
\hline
\end{tabular}




\section{REFERENCES}

Aizenman, J. (2003). Capital Mobility In A Second--Best World: Moral Hazard With Costly Financial Intermediation. Review of International Economics, 11(1), 1-17.

Akrasanee, N. (2008). Thai Financial Market and Its Significance. Paper presented at the Presentation at the 21th ACSIC Conference, Phuket, Thailand.

Alba, P., Hernandez, L., \& Klingebiel, D. (1999). Financial liberalization and the capital account: Thailand, 1988-97: The World Bank.

Allayannis, G., Brown, G. W., \& Klapper, L. F. (2003). Capital Structure and Financial Risk: Evidence from Foreign Debt Use in East Asia. The Journal of Finance, 58(6), 2667-2710.

Andrews, D. W. K. (1993). Tests for Parameter Instability and Structural Change with Unknown Change Point. Econometrica, 61(4), 821-856.

Andrews, D. W. K., \& Fair, R. C. (1988). Inference in Nonlinear Econometric Models with Structural Change. Review of Economic Studies, 55(4), 615-639.

Bank of Thailand. (2000). Supervision Report 2000.

Bekaert, G., \& Harvey, C. R. (2000). Foreign Speculators and Emerging Equity Markets. The Journal of Finance, 55(2), 565-613.

Bekaert, G., Harvey, C. R., \& Lundblad, C. (2005). Does financial liberalization spur growth? Journal of Financial Economics, 77(1), 3-55.

Bekaert, G., Harvey, C. R., Lundblad, C., \& Siegel, S. (2007). Global Growth Opportunities and Market Integration. The Journal of Finance, 62(3), 1081-1137.

Boyer, B. H., Kumagai, T., \& Yuan, K. (2006). How Do Crises Spread? Evidence from Accessible and Inaccessible Stock Indices. The Journal of Finance, 61(2), 957-1003.

Burnside, C., Eichenbaum, M., \& Rebelo, S. (2000). Understanding the Korean and Thai currency crises. Economic Perspectives(Q III), 45-60.

Burnside, C., Eichenbaum, M., \& Rebelo, S. (2001a). Hedging and financial fragility in fixed exchange rate regimes. European Economic Review, 45(7), 1151-1193.

Burnside, C., Eichenbaum, M., \& Rebelo, S. (2001b). Prospective Deficits and the Asian Currency Crisis. Journal of Political Economy, 109(6), 1155-1197.

Burnside, C., Eichenbaum, M., \& Rebelo, S. (2008). Currency Crisis Models. In New Palgrave Dictionary of Economics (2nd ed.). 
Cai, Z. (2007). Long Memory Models and Structural Changes. In Advanced Topics in Time Series Econometrics Using R (pp. 44-58).

Calvo, G. A. (1998). Capital Flows and Capital-Market Crises: The Simple Economics of Sudden Stops. Journal of Applied Economics, 0, 35-54.

Calvo, G. A., Leiderman, L., \& Reinhart, C. M. (1996). Inflows of Capital to Developing Countries in the 1990s. The Journal of Economic Perspectives, 10(2), 123-139.

Chang, R., \& Velasco, A. (2000). Financial Fragility and the Exchange Rate Regime. Journal of Economic Theory, 92(1), 1-34.

Chang, R., \& Velasco, A. (2001). A Model of Financial Crises in Emerging Markets. The Quarterly Journal of Economics, 116(2), 489-517.

Chari, V. V., \& Kehoe, P. J. (2003). Hot money. Journal of Political Economy, 111(6), 1262(1231).

Corbo, V., \& Hernandez, L. (1996). Macroeconomic Adjustment to Capital Inflows: Lessons from Recent Latin American and East Asian Experience. The World Bank Research Observer, 11(1), 61-85.

Corsetti, G., Pesenti, P., \& Roubini, N. (1999a). What caused the Asian currency and financial crisis? Japan and the World Economy, 11(3), 305-373.

Corsetti, G., Pesenti, P., \& Roubini, N. (1999b). Paper tigers?: A model of the Asian crisis. European Economic Review, 43(7), 1211-1236.

Dekle, R., \& Kletzer, K. (2005). Deposit Insurance Regulatory Forbearance and Economic Growth: Implications for the Japanese Banking Crisis: International Monetary Fund.

Disyatat, P. (2004). Currency crises and the real economy: The role of banks. European Economic Review, 48(1), 75-90.

Dooley, M. P. (2000). A Model of Crises in Emerging Markets. Economic Journal, 110(460), 256-272.

Edwards, S. (2001). Capital Mobility and Economic Performance: Are Emerging Economies Different? : National Bureau of Economic Research, Inc.

Edwards, S. (2004). Financial Openness, Sudden Stops, and Current-Account Reversals. The American Economic Review, 94(2), 59-64.

Expert Group on the Challenges of the Asian Economy and Financial Markets. (2001). Challenges of the Asian Economy and Financial Markets: Interim Summarization.

Fernandez-Arias, E., \& Montiel, P. J. (1996). The Surge in Capital Inflows to Developing Countries: An Analytical Overview. World Bank Econ Rev, 10(1), 51-77. 
Froot, K. A., O'Connell, P. G. J., \& Seasholes, M. S. (2001). The portfolio flows of international investors. Journal of Financial Economics, 59(2), 151-193.

Froot, K. A., \& Ramadorai, T. (2001). The Informational Content of International Capital Flow. NBER Working Paper 8472.

Froot, K. A., \& Ramadorai, T. (2005). Currency Returns, Intrinsic Value, and Institutional-Investor Flows. The Journal of Finance, 60(3), 1535-1566.

Furman, J., Stiglitz, J. E., Bosworth, B. P., \& Radelet, S. (1998). Economic Crises: Evidence and Insights from East Asia. Brookings Papers on Economic Activity, 1998(2), 1-135.

Giannetti, M. (2007). Financial liberalization and banking crises: The role of capital inflows and lack of transparency. Journal of Financial Intermediation, 16(1), 32-63.

Hansen, B. E. (2000). Testing for structural change in conditional models. Journal of Econometrics, 97(1), 93-115.

Hansen, B. E. (2001). The New Econometrics of Structural Change: Dating Breaks in U.S. Labour Productivity. The Journal of Economic Perspectives, 15(4), 117-128.

Hau, H., \& Rey, H. (2004). Can Portfolio Rebalancing Explain the Dynamics of Equity Returns, Equity Flows, and Exchange Rates? The American Economic Review, 94(2), 126-133.

Hau, H., \& Rey, H. (2006). Exchange Rates, Equity Prices, and Capital Flows. Review of Financial Studies, 19(1), 273-317.

Henry, P. B. (2000a). Do stock market liberalizations cause investment booms? Journal of Financial Economics, 58(1-2), 301-334.

Henry, P. B. (2000b). Stock Market Liberalization, Economic Reform, and Emerging Market Equity Prices. The Journal of Finance, 55(2), 529-564.

Henry, P. B., \& Lorentzen, P. L. (2003). Domestic Capital Market Reform and Access to Global Finance: Making Markets Work. NBER Working Paper Series, Working Paper 10064.

Hutchison, M. M., \& Noy, I. (2006). Sudden stops and the Mexican wave: currency crises, capital flow reversals and output loss in emerging markets.(Author Abstract). The Journal of Development Economics, 79(1), 225(224).

Jetin, B. (2007). Thailand 10 years after the crisis: Beyond finance, the exhaustion of a lowproductivity growth regime? Paper presented at the Conference on " A Decade After: Recovery and Adjustment since the East Asian Crisis", Bangkok, Thailand.

Kaminsky, G. L., \& Reinhart, C. M. (1998). Financial Crises in Asia and Latin America: Then and Now. The American Economic Review, 88(2), 444-448. 
Kaminsky, G. L., \& Reinhart, C. M. (1999). The Twin Crises: The Causes of Banking and BalanceOf-Payments Problems. The American Economic Review, 89(3), 473-500.

Kraay, A., \& Ventura, J. (2000). Current Accounts In Debtor And Creditor Countries. The Quarterly Journal of Economics, 115(4), 1137-1166.

Kraay, A., \& Ventura, J. (2002). Current Accounts in the Long and Short Run: National Bureau of Economic Research, Inc.

Krugman, P. (1979). A Model of Balance-of-Payments Crises. Journal of Money, Credit and Banking, 11(3), 311-325.

Krugman, P. (2001). Crises: The Next Generation? Paper prepared for the Razin Conference.

McKinnon, R. I., \& Pill, H. (1996). Credible liberalizations and international capital flows: the overborrowing syndrome. In T. Ito \& A. O. Krueger (Eds.), Financial Deregulation and Integration in East Asia. Chicago: University of Chicago Press.

Obstfeld, M. (1986). Rational and Self-Fulfilling Balance-of-Payments Crises. The American Economic Review, 76(1), 72-81.

Obstfeld, M., \& Rogoff, K. (1996). Foundations of International Macroeconomics. Cambridge, Massachusetts: MIT Press.

Poapongsakorn, N., Charnvitayapong, K., Laovakul, D., Suksiriserekul, S., \& Dahlby, B. (2000). A Cost-Benefit Analysis of the Thailand Taxpayer Survey. International Tax and Public Finance, $7(1), 63-82$.

Powell, A., Ratha, D., \& Mohapatra, S. (2002). Capital Inflows and Capital Outflows: Measurement, Determinants, Consequences: Universidad Torcuato Di Tella.

Prasad, E. S., Rogoff, K., Wei, S.-J., \& Kose, M. A. (2003). Effects of Financial Globalization on Developing Countries: Some Empirical Evidence. IMF Occasional Paper, 220.

Quinn, D. (1997). The Correlates of Change in International Financial Regulation. The American Political Science Review, 91(3), 531-551.

Radelet, S., Sachs, J. D., Cooper, R. N., \& Bosworth, B. P. (1998). The East Asian Financial Crisis: Diagnosis, Remedies, Prospects. Brookings Papers on Economic Activity, 1998(1), 1-90.

Rodrik, D. (1998). Who Needs Capital-Account Convertibility? Essays in International Finance No.207, International Finance Section, Department of Economics, Princeton University.

Rodrik, D., \& Velasco, A. (1999). Short-Term Capital Flows. National Bureau of Economic Research Working Paper Series, No. 7364. 
Schmitt-Grohe, S., \& Uribe, M. (2003). Closing small open economy models. Journal of International Economics, 61(1), 163-185.

Siamwalla, A., Vajragupta, Y., \& Vichyanond, P. (1999). Foreign Capital Flows to Thailand: Determinants and Impact. Thailand Development Research Institute.

Siourounis, G. (2003). Capital Flows and Exchange Rates: An Empirical Analysis: London Business School.

Stiglitz, J. E. (1999). Reforming the Global Economic Architecture: Lessons from Recent Crises. The Journal of Finance, 54(4), 1508-1521.

Stiglitz, J. E. (2002). Globalization and Its Discontents. New York: W. W. Norton.

Stock, J. H., \& Watson, M. W. (1996). Evidence on Structural Instability in Macroeconomic Time Series Relations. Journal of Business \& Economic Statistics, 14(1), 11-30.

Stulz, R. M. (2005). The Limits of Financial Globalization. The Journal of Finance, 60(4), 1595-1638.

Tinakorn, P. (2006). Indicators and Analysis of Vulnerability to Currency Crisis: Thailand. In Recent Financial Crises: Analysis, Challenges, and Implications: Edward Elgar Publishing.

Ventura, J. (2003). Towards a Theory of Current Accounts. The World Economy, 26(4), 483-512.

Vitale, P. (2007). A Guided Tour Of The Market Microstructure Approach To Exchange Rate Determination. Journal of Economic Surveys, 21(5), 903-934.

Zhou, Y. S. (2008). Capital Flows and Economic Fluctuations: The Role of Commercials Banks in Transmitting Shocks. SSRN eLibrary. 